


\section{Zonneparken natuur en landbouw}

Friso van der Zee ${ }^{1}$, Jaap Bloem ${ }^{1}$, Paul Galama², Luuk Gollenbeek ${ }^{2}$, Jaap van Os ${ }^{1}$, Alex Schotman ${ }^{1} \&$ Sjerp de Vries $^{1}$

1 Wageningen Environmental Research

2 Wageningen Livestock Research

Dit onderzoek is uitgevoerd door Wageningen Environmental Research in opdracht van en gefinancierd door het ministerie van Landbouw, Natuur en Voedselkwaliteit, in het kader van het Beleidsondersteunend onderzoekthema 'Ecologische Basiskwaliteit Land' (projectnummer BO-43-021.01-024).

Wageningen Environmental Research

Wageningen, april 2019

Gereviewd door:

Wieger Wamelink, senior onderzoeker (WEnR)

Akkoord voor publicatie:

R. Franken, teamleider van Biodiversiteit en Beleid

Rapport 2945

ISSN 1566-7197 
Zee, F.F. van der, J. Bloem, P. Galama, L. Gollenbeek, J. van Os, A. Schotman \& S. de Vries, 2019. Zonneparken natuur en landbouw. Wageningen, Wageningen Environmental Research, Rapport 2945. 68 blz.; 27 fig.; 3 tab.; 112 ref.

Referaat NL De transitie naar duurzame energie is in volle gang. Er ligt een grote opgave om met duurzame energiebronnen aan onze energiebehoefte te voldoen. Zonnestroom en de aanleg van zonneparken maken momenteel een sterke groei door. In 2018 is het geïnstalleerde zonnevermogen met $46 \%$ toegenomen. Het areaal zonneparken op de grond groeit snel maar niet sneller dan de oppervlakte zonnepanelen op daken. In Nederland is er discussie over het inzetten van de schaarse ruimte voor het plaatsen van zonnepanelen. Het benutten van daken op nieuwe en bestaande gebouwen is een efficiënt gebruik van de ruimte, maar het buitengebied biedt ontwikkelaars van zonneparken veel voordelen, zoals schaalgrootte. $\mathrm{Er}$ is nog maar weinig onderzoek gedaan naar de effecten van zonneparken op natuur, landbouw en landschap. Grondgebonden zonneparken hebben effecten op de bodem, landbouw, de aanwezige biodiversiteit en diensten die het landschap levert. Of die effecten positief of negatief zijn, hangt af van de uitgangssituatie op de betreffende locatie en van de inrichting en het beheer van het zonnepark. Deze studie geeft een overzicht van de literatuur over zonneparken in relatie tot bodem, landbouw, biodiversiteit en beleving.

Referaat UK The transition to sustainable energy is in full swing. There is a great challenge to meet our energy requirements with sustainable energy sources. Solar power and the construction of solar parks are currently experiencing strong growth. In 2018 the solar power installed has increased by $46 \%$. The area of solar parks on the ground is growing faster than the surface solar panels on roofs. In the Netherlands there is discussion about the use of scarce space for installing solar panels. The use of roofs on new and existing buildings is an efficient use of space, but the outdoor area offers developers of solar parks many advantages, such as scale. Little research has been done into the effects of solar parks on nature, agriculture and landscape. Ground-based solar parks have effects on the soil, agriculture, the biodiversity and services that the landscape provides. Whether these effects are positive or negative depends on the initial situation at the location in question and on the design and management of the solar park. This study provides an overview of the literature on solar parks in relation to soil, agriculture, biodiversity and experience.

Trefwoorden: zonneparken, zonne-energie, bodem, landbouw, natuur, biodiversiteit, beleving

Dit rapport is gratis te downloaden van https://doi.org/10.18174/475349 of op

www.wur.nl/environmental-research (ga naar 'Wageningen Environmental Research' in de grijze balk onderaan). Wageningen Environmental Research verstrekt geen gedrukte exemplaren van rapporten.

2019 Wageningen Environmental Research (instituut binnen de rechtspersoon Stichting Wageningen Research), Postbus 47, 6700 AA Wageningen, T 03174807 00, www.wur.nl/environmental-research. Wageningen Environmental Research is onderdeel van Wageningen University \& Research.

- Overname, verveelvoudiging of openbaarmaking van deze uitgave is toegestaan mits met duidelijke bronvermelding.

- Overname, verveelvoudiging of openbaarmaking is niet toegestaan voor commerciële doeleinden en/of geldelijk gewin.

- Overname, verveelvoudiging of openbaarmaking is niet toegestaan voor die gedeelten van deze uitgave waarvan duidelijk is dat de auteursrechten liggen bij derden en/of zijn voorbehouden.

Wageningen Environmental Research aanvaardt geen aansprakelijkheid voor eventuele schade voortvloeiend uit het gebruik van de resultaten van dit onderzoek of de toepassing van de adviezen.
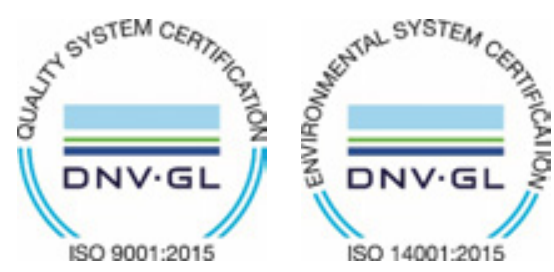

Wageningen Environmental Research werkt sinds 2003 met een ISO 9001 gecertificeerd kwaliteitsmanagementsysteem. In 2006 heeft Wageningen Environmental Research een milieuzorgsysteem geïmplementeerd, gecertificeerd volgens de norm ISO 14001.

Wageningen Environmental Research geeft via ISO 26000 invulling aan haar maatschappelijke verantwoordelijkheid.

Wageningen Environmental Research Rapport 2945 | ISSN 1566-7197

Foto omslag: Stichting Solarlandschapspark de Kwekerij. 


\section{Inhoud}

Verantwoording $\quad 5$

$\begin{array}{ll}\text { Samenvatting } & 7\end{array}$

1

$\begin{array}{ll}\text { Inleiding } & 9\end{array}$

1.1 Achtergrond 9

1.2 Probleemstelling \& doel 10

$\begin{array}{lll}1.3 \text { Werkwijze } & 11\end{array}$

Zonnestroom: stand van zaken 2019

2.1 Sterke groei zonnestroom 12

2.2 Zonneparken sociaal-economisch 14

$\begin{array}{ll}2.3 \text { Locatiekeuze van zonneparken } & 15\end{array}$

2.4 Monitoring van het areaal zonneparken $\quad 17$

2.5 Conclusies en kennisleemten 19

$\begin{array}{ll}\text { De bodem onder zonnepanelen } & \mathbf{2 0}\end{array}$

$\begin{array}{lll}3.1 & \text { Functies van de bodem } & 20\end{array}$

$\begin{array}{lll}3.2 & \text { De levende bodem } & 21\end{array}$

3.3 Effecten van zonneparken op bodem en bodembiodiversiteit 22

3.4 Verwachte effecten op bodem-ecosysteemdiensten $\quad 25$

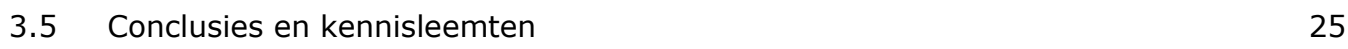

4 Consequenties voor de landbouw $\quad 27$

$\begin{array}{lll}4.1 & \text { Vraag en aanbod landbouwgrond } & 27\end{array}$

4.2 Effect van zonneparken op de prijs van landbouwgrond 29

4.3 Zonneparken als tweede tak 30

4.4 Landbouwproductie onder zonnepanelen 33

4.5 Gevolgen zonneparken op bodemvruchtbaarheid landbouwgrond 37

4.6 Combinatiemogelijkheden zonnepanelen en landbouw 38

$\begin{array}{lll}4.7 & \text { Conclusies en kennisleemten } & 39\end{array}$

$5 \quad$ Biodiversiteit en zonneparken $\quad 42$

5.1 Zonneparken als leefgebied $\quad 42$

5.2 Beheer zonneparken voor biodiversiteit $\quad 45$

5.3 Natuurbeschermingsdoelen van zonneparken $\quad 46$

5.4 Ruimtelijke aspecten van zonneparken voor biodiversiteit $\quad 48$

$\begin{array}{lll}5.5 & \text { Zonnepanelen op water } & 48\end{array}$

$\begin{array}{lll}5.6 & \text { Conclusies en kennisleemten } & 51\end{array}$

6 De beleving van zonneparken $\quad 53$

6.1 Definities 53

6.2 Minimaliseren negatieve impact zonneparken qua belevingswaarde $\quad 54$

6.3 Maatschappelijke acceptatie van zonneparken $\quad 57$

6.4 Conclusies en kennisleemten $\quad 59$ 



\section{Verantwoording}

Rapport: 2945

Projectnummer: 5200045208

Wageningen Environmental Research (WENR) hecht grote waarde aan de kwaliteit van onze eindproducten. Een review van de rapporten op wetenschappelijke kwaliteit door een referent maakt standaard onderdeel uit van ons kwaliteitsbeleid.

Akkoord Referent die het heeft beoordeeld,

functie: $\quad$ Senior onderzoeker

naam: Wieger Wamelink

datum: $\quad$ 15-04-2019

Akkoord teamleider voor de inhoud,

naam: R. Franken

datum: 15-04-2019 


\section{Samenvatting}

De transitie naar duurzame energie is in volle gang. Er ligt een grote opgave om met duurzame energiebronnen aan onze energiebehoefte te voldoen. Zonnestroom en de aanleg van zonneparken maken momenteel een sterke groei door. In 2018 is het geïnstalleerde zonnevermogen met $46 \%$ toegenomen. Het areaal zonnepanelen op daken is groter dan het areaal op land, maar het areaal zonneparken op de grond groeit snel. In Nederland is er discussie over het inzetten van de schaarse ruimte voor het plaatsen van zonnepanelen. Het benutten van daken op nieuwe en bestaande gebouwen is een efficiënt gebruik van de ruimte, maar het buitengebied biedt ontwikkelaars van zonneparken veel voordelen, zoals schaalgrootte. Er is nog maar weinig onderzoek gedaan naar de effecten van zonneparken op natuur, landbouw en landschap. Grondgebonden zonneparken hebben effecten op de bodem, landbouw, de aanwezige biodiversiteit en diensten die het landschap levert. Of die effecten positief of negatief zijn, hangt af van de uitgangssituatie op de betreffende locatie en van de inrichting en het beheer van het zonnepark. Deze studie geeft een overzicht van de literatuur over zonneparken in relatie tot bodem, landbouw, biodiversiteit en beleving.

Veel van de huidige zonneparken zijn gericht op het halen van een zo hoog mogelijke elektriciteitsproductie per hectare. Dat betekent zo veel mogelijk panelen per hectare. De meest voorkomende vormen zijn een zuidopstelling en een oost-westopstelling. Bij een zuidopstelling hebben de panelen een hellingshoek van 25-40 graden, bij een oost-westopstelling is de hellingshoek lager en zijn er ca. twee keer zoveel panelen nodig. De hoogte, het aantal panelen en de hellingshoek bepalen de hoeveelheid licht die nog op de bodem komt en de verdeling van het neerslagwater. Dit bepaalt in sterke mate het effect van zonneparken op de bodem en biodiversiteit en de mogelijkheden om zonneparken met landbouw en natuur te combineren. Er liggen zeker kansen voor functiecombinaties, maar daarvoor zal gezocht moeten worden naar een optimum tussen maximale stroomproductie en andere functies.

Voor de bodem geldt dat minder licht en een andere verdeling van het water via minder planten(wortels) zullen leiden tot minder bodemleven, lagere organische stofgehalten en een afname van de bodemvruchtbaarheid. Dit is met name van belang als de grond later weer voor landbouw gebruikt zou worden. Een inschatting is dat herstel van het organische stofgehalte in de bodem dan minimaal tien jaar duurt. Theoretisch is netto-opslag van koolstof haalbaar in zonneparken. Dit zou gunstig zijn voor het klimaat.

Landbouweconomisch blijkt dat een zonnepark financieel momenteel duidelijk meer oplevert dan grondgebonden veehouderij of akkerbouw. Voor stoppende boeren en akkerbouwers kan het een verleidelijk alternatief zijn, waarmee echter de ontwikkelingsruimte voor blijvende bedrijven wordt beperkt. Voor melkveehouders is de voor voerproductie en mestverwerking beschikbare grond een belangrijke factor, waardoor minder snel gekozen wordt voor zonneparken. Of de aanleg van een zonnepark voor een ontwikkelaar financieel aantrekkelijk is, hangt ook in sterke mate af van de kosten voor aansluiting op het net. De kosten tot aan het openbare net zijn voor de initiatiefnemer, dus hoe groter die afstand, hoe hoger de kosten. Verder lijkt een groot scala aan combinaties van landbouw en zonneparken mogelijk door panelen op hoogte te installeren, op en rond erven of langs perceelranden. De combinatie met een uitloop van dieren (jongvee, melkvee, varkens of pluimvee) vergt aanvullend beleid (milieu en dierenwelzijn) dat eisen stelt aan de uitloop. Over de effecten van spreiding van zonnepanelen, concentratie op enkele ha's in plaats van spreiding over een groter areaal landbouwgrond, op de gewasproductie en het dierenwelzijn van weidende dieren is nog onvoldoende bekend in Nederlandse omstandigheden.

Voor natuur liggen er volop kansen op zonneparken en zeker in intensief agrarisch gebied zou een zonnepark kunnen bijdragen aan verhoging van de biodiversiteit. De focus is vooral op vegetatie, insecten en een aantal vogelsoorten. De praktijk is echter dat dit in veel gevallen nog weinig aandacht heeft. Cruciaal voor een combinatie zonnepark en biodiversiteit is dat er voldoende licht en water op 
de bodem blijft komen. En alleen het inzaaien van een bloemrijk mengsel is onvoldoende, essentieel daarbij is het beheer. $\mathrm{Er}$ is bij het ontwerp van zonneparken te weinig aandacht voor het langjarig beheer na realisatie van het zonnepark. Dit zou, meer dan nu het geval is, direct bij het ontwerp meegenomen moeten worden om biodiversiteitsdoelen daadwerkelijk te halen. Soms geven provincies aan projectontwikkelaars van zonneparken de randvoorwaarde mee om na realisatie de biodiversiteit te blijven monitoren. Dit is nuttig en kan het best op een gestandaardiseerde manier worden uitgevoerd, zodat gegevens, die openbaar beschikbaar moeten zijn, ook gebruikt kunnen worden voor uitgebreidere onderzoeken.

Zonnepanelen op het water zijn ook kansrijk en hebben waarschijnlijk minder nadelen (verlies landbouwgrond, beleving landschap) dan zonnepanelen op land. Daarbij hebben tweezijdige panelen die het wateroppervlak niet volledig afdekken ecologisch gezien de voorkeur boven enkelzijdige panelen op pontons, die het wateroppervlak afsluiten van licht.

De belevingswaarde, met name in de zin van hoe mooi mensen het landschap vinden, zal door het realiseren van een zonnepark doorgaans afnemen. Daarmee is niet gezegd dat men zo'n zonnepark onacceptabel vindt; uit milieuoverwegingen kan men hier bijvoorbeeld toch voor zijn. Voor de acceptatie van het (realiseren van een) zonnepark maakt het uit of de omwonenden bij het proces betrokken zijn en zich serieus genomen voelen en of zij hier zelf ook financieel baat bij hebben (dan wel gecompenseerd worden), alhoewel het geen garanties biedt voor een groot maatschappelijk draagvlak. Qua beleving zal de negatieve impact van een zonnepark groter zijn naarmate het landschap in z'n huidige staat hoger gewaardeerd wordt. Meer natuurlijke omgevingen lijken op dit punt minder geschikt dan landbouwgebieden. Maar een andere factor is hoeveel mensen hoe vaak met het zonnepark geconfronteerd worden. Daarvoor geldt: minder is beter. Dit betekent echter weer niet dat inpassing met hagen automatisch de beste oplossing is, zeker niet in open landschappen.

Landschappelijke inpassing is altijd maatwerk.

Het is op basis van de huidige kennis niet mogelijk om in algemene zin een voorkeursvolgorde aan te geven op grond van te verwachten effecten en kansen voor bodem, natuur en landschap. Dit geldt ook voor verschillen binnen landbouwgebieden in effecten tussen typen graslanden, akkers en tuinbouwgebieden. In de praktijk is het altijd maatwerk. Hier liggen dan ook nog grote kennisleemtes. Bij alle deelonderwerpen bodem, landbouw, biodiversiteit en beleving wordt geconstateerd dat we nog te weinig weten om een optimum te vinden tussen maximale energieproductie en andere functies. Dus om verder te komen dan expert judgement, is onderzoek nodig. Per onderwerp staat in het rapport aangegeven waar dit onderzoek zich op zou moeten richten en hoe dat er globaal uit zou kunnen zien. Het monitoren van effecten in bestaande zonneparken is een voor de hand liggende eerste stap.

Hiermee kunnen in meer detail inrichtingsprincipes en randvoorwaarden worden ontwikkeld waarbij er voldoende ruimte blijft voor natuur, landbouw en landschap. Het is aan provincies en gemeenten om te bepalen in hoeverre ze daar vervolgens sturend mee om willen gaan. 


\section{$1 \quad$ Inleiding}

$\mathrm{Er}$ is behoefte aan een overzicht van de kennis over zonneparken in relatie tot natuur, bodem, landbouw en beleving. De aanleiding voor het maken van dit kennisoverzicht is de Tweede Kamermotie van het lid Dik-Faber van 27 september 2018. Daarin wordt vastgesteld:

1. dat er vele bouwplannen klaarliggen voor grootschalige zonneparken op natuur- en landbouwgrond,

2. dat een brede coalitie van de Rijksadviseur voor de fysieke leefomgeving, Rijksinstituut voor Volksgezondheid en Milieu (RIVM), Sovon Vogelonderzoek Nederland, boeren- en natuurorganisaties en netbeheerders pleit voor een ruimtelijk afwegingskader,

3. dat het opofferen van landbouwgrond lokaal effect kan hebben op grondprijzen,

4. dat natuurbeschermers en ecologen waarschuwen voor de negatieve gevolgen van grote zonneparken op kwetsbare natuur en op het bodemleven,

5. dat netbeheerders te laat in het proces worden betrokken voor het realiseren van de aansluiting,

6. dat zonne-energie onmisbaar is voor het halen van de klimaatdoelen, maar dat er nog veel onbenutte ruimte is voor zonnepanelen op daken van huizen, scholen, kantoren, parkeergarages, op bedrijventerreinen, braakliggende terreinen, vuilstorten en langs infrastructurele werken zoals geluidsschermen,

7. dat de ladder voor duurzame verstedelijking bedoeld is voor locaties voor woningen, winkels en kantoren en niet voor de inpassing van zonnepanelen,

8. dat de verkenning naar een afwegingskader van de Rijksdienst voor Ondernemend Nederland laat zien dat provincies en gemeenten allemaal hun eigen ruimtelijk kader hanteren,

9. dat ook zaken zoals de participatie van omwonenden onvoldoende geregeld zijn,

10. dat het Klimaatakkoord wordt vertaald in regionale energiestrategieën.

De motie verzoekt de regering:

- in samenspraak met decentrale overheden een 'zonneladder' op te stellen voor de inpassing van zonne-energie, die als nationaal afwegingskader kan worden benut bij het opstellen van regionale energiestrategieën, zodat primair onbenutte daken en terreinen worden benut en landbouw en natuur zo veel mogelijk worden ontzien;

- hierbij de landbouwsector, de zonne-energiesector en netbeheerders te betrekken;

- deze sturingsinstrumenten voor ruimtelijke inpassing en participatie conform de systematiek van de Omgevingswet te verankeren in rijksbeleid (bijvoorbeeld de NOVI) en waar nodig ook regelingen aan te passen die belemmerend werken, zodat daken beter kunnen worden benut voor het opwekken van zonne-energie en zo nodig hier ook met decentrale overheden afspraken over te maken;

- tevens de Kamer in januari 2019 te informeren hoe de gesprekken met decentrale overheden zijn verlopen.

Om aan dit verzoek tegemoet te komen, heeft het ministerie van EZK een opdracht uitgezet aan Bosch en Van Rijn, gericht op het inventariseren van de nu door decentrale overheden gehanteerde toetsingskaders en het ruimtelijk beleid m.b.t. zonneparken. Het ministerie van LNV heeft een opdracht aan Wageningen Environmental Research gericht op het leveren van kennis en inzicht in de effecten van zonnepanelen/-parken op natuur, landschap, bodem en landbouwsector. Het project moet bouwstenen leveren voor het beantwoorden van de vragen uit de motie in januari 2019 en.

\section{$1.1 \quad$ Achtergrond}

De transitie naar duurzame energie is in volle gang. Er ligt een grote opgave om met duurzame energiebronnen aan onze energiebehoefte te voldoen. In het landschap verschijnen niet alleen steeds meer en steeds hogere windmolens, maar ook nemen zonneparken met zonnepanelen steeds meer ruimte in. In Nederland is discussie over het inzetten van de schaarse ruimte voor het plaatsen van 
zonnepanelen. Het benutten van daken op nieuwe en bestaande gebouwen is een efficiënt gebruik van de ruimte, maar het buitengebied biedt ontwikkelaars van zonneparken veel voordelen, zoals schaalgrootte. Voor boeren, zeker zonder bedrijfsopvolger, is een zonnepark vaak een aantrekkelijk economisch perspectief. De vraag is of en hoe grondgebonden zonneparken ontwikkeld kunnen worden met behoud van de agrarische functie of voor een nevenfunctie voor natuur. Hoe voorkom je monoculturen van zonnepanelen op plekken waar ook andere waarden van belang zijn? Op welke manieren zijn grondgebonden zonneparken en natuur te combineren? Hoe kom je tot een balans tussen economisch voldoende rendabele zonneparken en de ontwikkeling van natuur op hetzelfde terrein? Wat is een optimale verdeling tussen door zonnepanelen bedekte grond en open terrein? Bieden nieuwe vormen van zonnepanelen, zoals 'bifacial' panelen die staand in plaats van liggend geplaatst kunnen worden, ook nieuwe, betere mogelijkheden voor functiecombinaties? Kan een zonnepark een buffer vormen tussen (kwetsbare) natuur en agrarisch gebied omdat er geen meststoffen worden gebruikt en het grondwaterpeil omhoog kan?

\subsection{Probleemstelling \& doel}

In de kabinetsappreciatie van het voorstel op hoofdlijnen voor een Klimaatakkoord ( 5 oktober jl. aan de Kamer aangeboden) staat het volgende: "Conform de motie Dik-Faber (Kamerstuk 32 813, nr. 204) wordt in samenspraak met decentrale overheden een 'zonneladder' ontwikkeld die richting geeft aan het benutten van de schaarse ruimte voor de inpassing van zonne-energie. Het rijk geeft daarbij al richting door de voorkeur uit te spreken voor zon op daken of zonneweides in landelijk gebied met lage landschappelijke, ecologische of landbouwkundige waarde en het maximaal benutten van grootschalige clustering op land voor de opwekking van duurzame energie (wind en waar nodig ook zon). Het kabinet vraagt hier specifiek ook aandacht voor zon-PV en brengt, met andere partijen, in beeld welke mogelijkheden er zijn om de toepassing van zonnepanelen te bevorderen."

Vanwege het bovenstaande is bij het ministerie van LNV behoefte aan kennis en inzicht in de effecten van zonnepanelen/-parken op natuur, landschap, bodem en landbouwsector. Gevraagd is om een inventarisatie uit te voeren naar bestaande, (inter)nationale kennis op dit gebied en daarbij aan te geven waar kennislacunes liggen.

\section{Projectdoelstelling}

Doelstelling van het project is het leveren van kennis en inzicht in de effecten van zonnepanelen/ -parken op natuur, landschap, bodem en op de landbouwsector.

\section{Kennisvragen:}

- Wat is bekend over de effecten van het langdurig plaatsen van zonnepanelen op bodemkwaliteit, natuur en landschap?

- 'Natuur' is meer dan bodemkwaliteit alleen. Het gaat daarbij bijvoorbeeld ook om de oriëntatiemogelijkheden voor vleermuizen, nestelgelegenheid van vogels, beschikbaarheid van voedsel, ook voor bijen en bestuivers e.d. Wat is hierover, of over andere planten- en diergroepen, reeds bekend?

- Het effect op landschap heeft sterk met de beleving door mensen te maken. Wat is er bekend over de beleving en acceptatie door mensen van zonneparken in hun omgeving? Is de acceptatie door mensen groter indien zij (financieel) betrokken zijn bij de ontwikkeling en exploitatie van dergelijke parken?

- Hoe kan bij de locatiekeuze voor zonneweides het best rekening worden gehouden met de gevolgen voor bodemkwaliteit, natuur en landschap en kan daarvoor een voorkeursvolgorde worden aangegeven?

- Op welke wijze kan bij de inrichting van zonneweides zo goed mogelijk rekening worden gehouden met de effecten en de kansen voor bodem, natuur, landbouw en landschap?

- Welke wetenschappelijke kennis is er over zonneparken en effecten in de landbouwsector? Welke ontwikkelingen en effecten worden gezien in relatie tot beschikbaarheid/schaarste en prijzen van landbouwgrond en (on)mogelijkheden voor jonge boeren, bedrijfsuitbreiding en grondgebondenheid?

- Welke kennislacunes worden gesignaleerd? Welke aanbevelingen kunnen worden gedaan? 


\section{$1.3 \quad$ Werkwijze}

De kennisvragen zijn door onderzoekers met de juiste kennis en ervaring en op basis van beschikbare literatuur (binnen- en buitenlands), data en informatie beantwoord. Voor de beantwoording is een literatuuronderzoek uitgevoerd. Bevindingen in wetenschappelijke publicaties over mogelijke effecten van zonnepanelen op bodemkwaliteit, natuur en landschap zijn op een rij gezet. Nietwetenschappelijke literatuur is als inspiratiebron ook meegenomen. Besloten is om een indeling te maken naar de vier deelonderwerpen: Bodem, Landbouw, Biodiversiteit en Beleving. In het hoofdstuk Biodiversiteit is een paragraaf 'Zonnepanelen op water' toegevoegd.

Op basis van de literatuurstudie is besproken hoe de verzamelde kennis benut zou kunnen worden voor een beoordeling van de Regionale Energie Strategie (RES) en de inrichting van individuele zonneweides met het oog op natuur, landbouw etc. Het project levert bouwstenen om de motie te beantwoorden. 


\section{Zonnestroom: stand van zaken 2019}

\subsection{Sterke groei zonnestroom}

Het geïnstalleerde zonnestroomvermogen in Nederland is in 2018 met $46 \%$ gegroeid. In onderstaande figuren is te zien dat er in 20181.330 MWp geïnstalleerd zonne-energievermogen is bijgekomen. Hiermee is het totaal opgestelde zonnestroomvermogen in Nederland in één jaar gegroeid van 2,9 GWp naar 4,2 GWp (Nationaal Solar Trendrapport 2019). De Nederlandse markt groeit in 2018 bijna twee keer zo hard als de wereldwijde markt. De kosten van zonnepanelen op de Europese markt zijn de afgelopen 12 maanden gedaald en de verwachting is dat dit de komende jaren zal doorzetten.

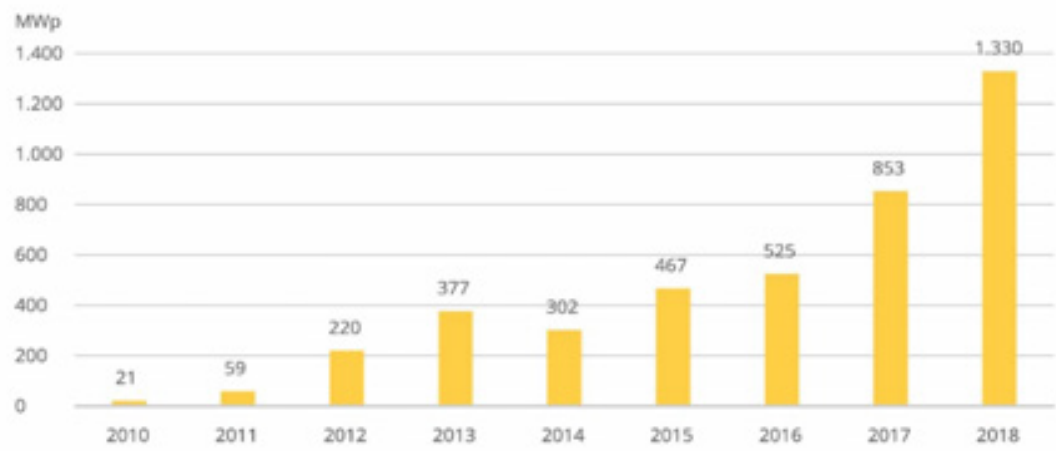

Figuur 1 Jaarlijks geïnstalleerd zonnestroomvermogen in Nederland (Bron: Solar Trend Rapport 2019)

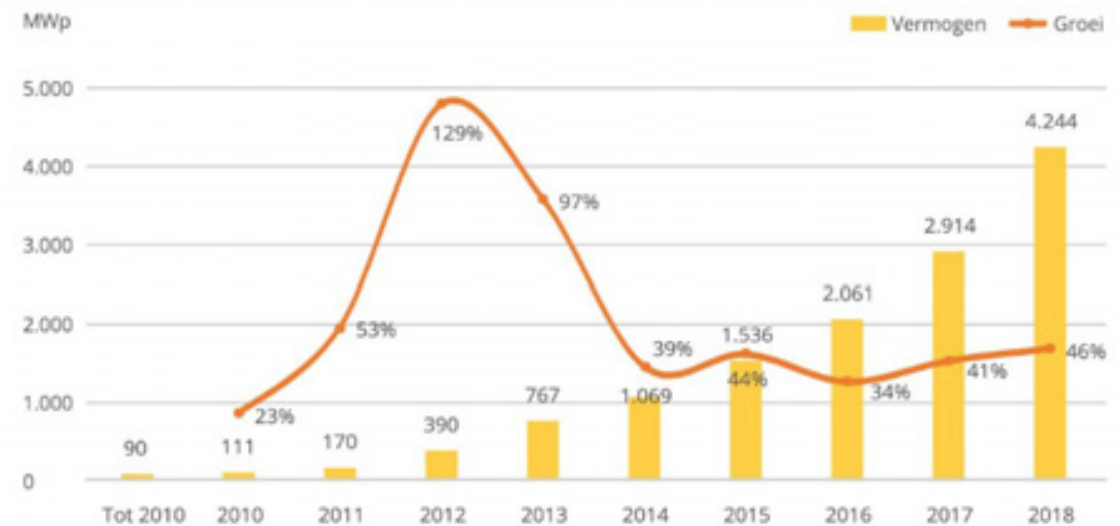

Figur 2 Totaal geïnstalleerd zonnestroomvermogen in Nederland (Bron: Solar Trend Rapport 2019)

In 2018 is $62 \%$ van het geïnstalleerde vermogen in de zakelijke sector geplaatst en $38 \%$ in de residentiële sector. In vergelijking met 2017 is zowel de zakelijke als de residentiële markt gegroeid. De zakelijke markt groeit echter harder, doordat een relatief groter deel van de SDE+ subsidie naar zonnestroom gaat (zie figuur 3). Ook in de zakelijke sector wordt een groot deel op daken gerealiseerd. Het groter aandeel zakelijk betekent dus niet automatisch dat het aandeel opstellingen op de grond 
toeneemt. Dit komt onder andere door de sterke prijsdaling die zonnestroom doormaakt en doordat de ontwikkeling van technieken zoals wind op land en biomassa relatief vaker vertraging oplopen en meer capaciteit en tijd vereisen. Tegelijkertijd is het SDE+-budget de afgelopen jaren zeer sterk uitgebreid (van $€$ 3,5 miljard in 2015 naar $€ 12$ miljard in 2017 en 2018) en is het bijstoken van biomassa uitgesloten van deelname. In Nederland is grofweg $800 \mathrm{~km}^{2}$ dakoppervlak geschikt voor zonnepanelen, daarvan is momenteel (2019) ca. $5 \%\left(40 \mathrm{~km}^{2}\right)$ benut. Voor grond is de verwachte benutting voor 2030 $35 \mathrm{~km}^{2}$ (Holland Solar 2018).

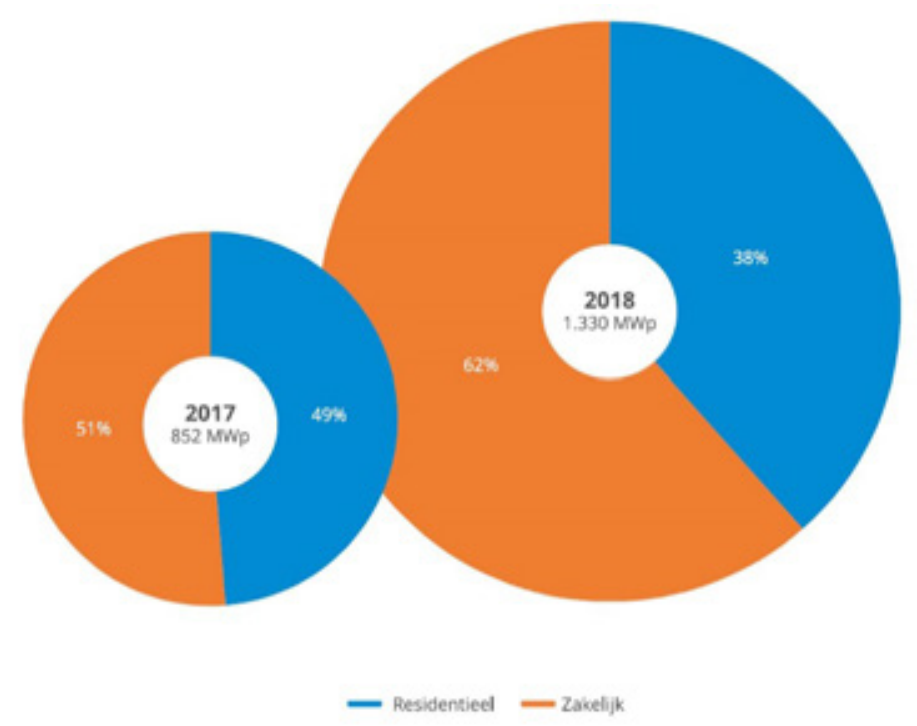

Figuur 3 Totaal geïnstalleerd zonnestroomvermogen 2017 en 2018 opgesplitst naar residentieel en zakelijk (blauw). Bron: Nationaal Solar Trendrapport 2019.

Het aandeel zonnestroom in totale elektriciteitsproductie is gegroeid tot 3,3\%. Op basis van het geïnstalleerde vermogen is er 4.244 MWp zonnestroomvermogen beschikbaar aan het eind van 2018. Dit vermogen leidt tot een elektriciteitsproductie van ongeveer 3,8 TWh op jaarbasis, oftewel 3,3\% van de totale netto Nederlandse elektriciteitsproductie. Dit is goed voor $1,8 \%$ van de totale energievraag in Nederland (figuur 4).

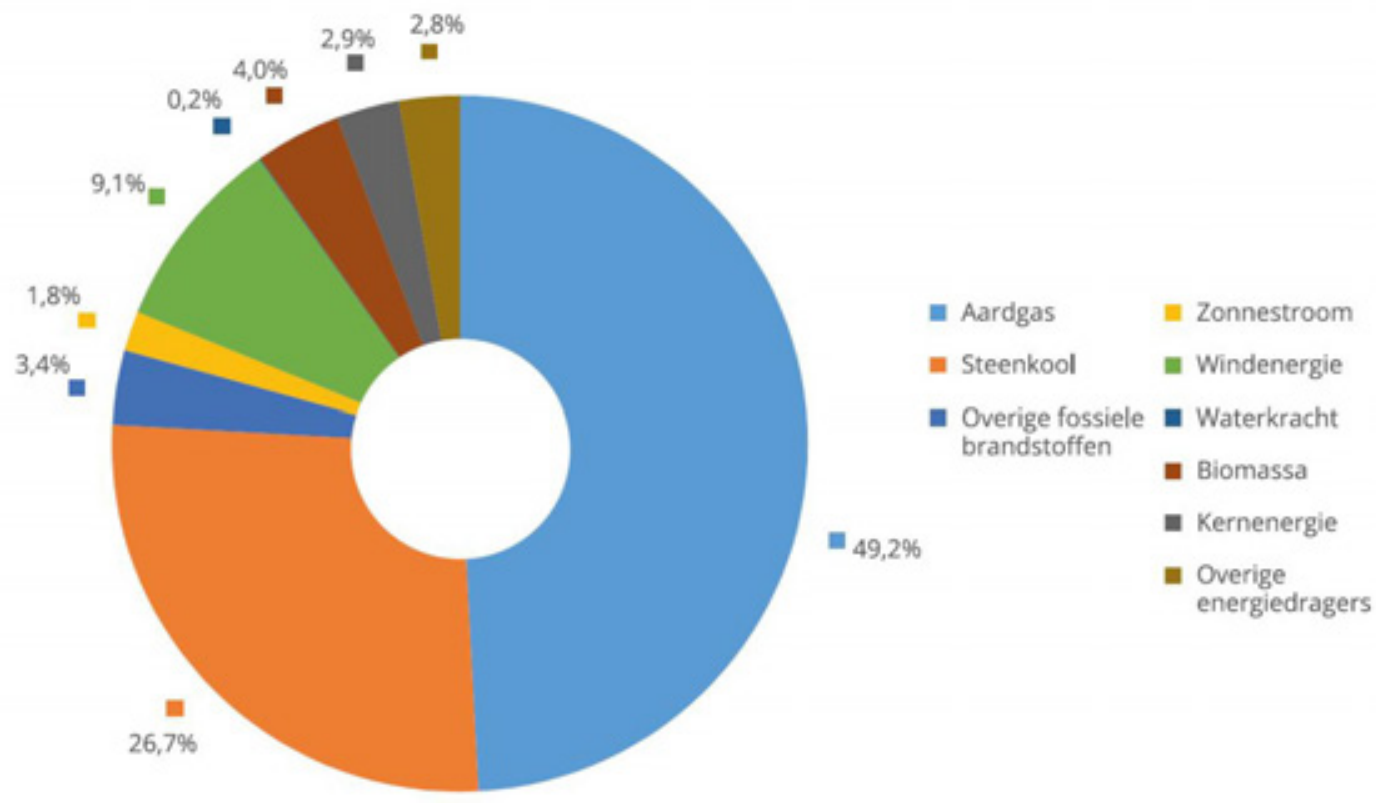

Figuur $4 \quad$ Elektriciteit en warmte; productie en inzet naar energiebron.

Centraal Bureau Statistiek 12 juli 2018. 


\subsection{Zonneparken sociaal-economisch}

Het realiseren van een zonnepark vergt vaak een intensief proces. De volgende stappen moeten worden doorlopen, om van de ontwikkeling van idee naar een zonnepark voor een bepaalde locatie te komen:

- Aanvraag van een omgevingsvergunning. Meestal is aanpassing van het bestemmingsplan nodig. In de praktijk blijkt dat soms een tijdelijke vergunning ook kan voldoen (https://www.boerderij.nl/Home/Achtergrond/2018/7/Zonnepark-niet-zonder-meer-aantrekkelijk315946E/).

- Aanvraag van de subsidie, die nu nog nodig is om het verschil tussen de kostprijs en de stroomafname prijs te dekken. Op beperkte schaal worden in Engeland en Duitsland al zonneparken zonder subsidie gerealiseerd. In China is dit vanaf 2019 algemeen beleid.

- Aanvraag van de financiering, de investeringskosten van een zonnepark bedragen momenteel ca. $0,75 \mathrm{mln}$ euro per ha.

- Aanvraag van kabelinfrastructuur om de opgewekte stroom te kunnen leveren aan het net.

- Uitzoeken en/of aanvragen wat de fiscale gevolgen zijn van de omzetting van landbouw naar zonnepark.

- Uitzoeken wie (en in welke mate) willen participeren in het project.

- Aanleg van het park en de benodigde infrastructuur.

Adviesbureau ROM3D, dat bij veel projecten betrokken is, geeft aan dat trajecten in de praktijk van idee tot realisatie al snel drie jaar in beslag nemen. Hun ervaring is dat bij veel projecten op een bepaald moment weerstand ontstaat. Dit kan betrekking hebben op de beleving van het park of mogelijke negatieve effecten ervan op bv. landbouw en natuur. In het algemeen is bekend dat de weerstand kleiner wordt als omwonenden van het begin af aan betrokken zijn bij het idee of als er een mogelijkheid is om t.z.t. betrokken te worden bij de realisatie van het park; dit kan bv. door het bijdragen in investeringskosten in ruil voor levering van energie en korting op de energiebelasting. Hiervoor kan een energiecoöperatie worden opgericht of gebruikgemaakt worden van de postcoderoosregeling waarbij de deelnemers uit hetzelfde of het aangrenzende postcodegebied moeten komen. Er zijn diverse bedrijven die met softwarepakketten dergelijke samenwerkingen faciliteren en stimuleren.

In het landelijk gebied bestaan veel verschillende situaties waarin een zonnepark wordt gerealiseerd. Enkele voorbeelden:

- Een stoppend agrarisch bedrijf - er zijn investeringen in stallen nodig, maar gezien de omgeving past dat niet goed, terwijl enkele beschutte percelen beschikbaar zijn en een sterke kabelinfrastructuur; dan lijkt de omslag naar een zonnepark een goede keuze: https://www.boerderij.nl/Pluimveehouderij/Achtergrond/2019/1/Zonnepark-van-duurzame-kipnaar-duurzame-energie-384681E/?cmpid=NLC|boerderij_vandaag|2019-01-

23|Zonnepark:_van_duurzame_kip_naar_duurzame_energie

- Op voormalige vuilstortplaatsen en slibdepots in Groningen en Friesland heeft Herbo Groenleven grootschalige zonneparken gerealiseerd, waarbij het project in Friesland in nauwe samenwerking is verlopen met betrokken bewoners, via een energiecoöperatie.

- In Wierden is op 24 mei 2018 het zonnepark De Groene Weuste geopend, een terrein van 4,5 hectare aan de noordkant van Wierden, vermogen $4 \mathrm{MWp}$, stroomproductie voor 1300 huishoudens. Het is begonnen als burgerinitiatief, maar door de omvang was het te groot voor de postcoderoosregeling, daarom is gekozen voor een SDE+-aanvraag. Uitgangspunt was een maximale betrokkenheid van lokale bedrijven en dat het rendement zo veel mogelijk ten goede moest komen aan de Wierdense gemeenschap: het Wierdens model. De gemeente heeft de locatie geselecteerd en het bestemmingsplan gewijzigd. Het grenst aan een bedrijventerrein in ontwikkeling. https://www.rvo.nl/actueel/praktijkverhalen/snelle-realisatie-zonnepark-volgens\%E2\%80\%98wierdens-model\%E2\%80\%99-met-sde 
- Een plan in Raalte waarbij een melkveehouder 34 ha wil gaan verhuren aan Solar Provider Group; het voorgenomen park komt aan beide zijden van een weg te liggen en leidt tot protesten van omwonenden, die ijveren voor het behoud van het kleinschalige agrarische coulissenlandschap. https://www.destentor.nl/salland/buurt-richt-hoop-op-politiek-bij-protest-tegen-zonneparkstobbenbroekerweg a94f96e9/

Voor de ontwikkeling van een zonnepark is het niet per se nodig om de bestemming van de grond te wijzigen. Op 4 april 2018 heeft de Raad van State bepaald dat je zonneparken in principe als tijdelijk gebruik kunt zien, omdat een zonnepark en beperkte levensduur heeft en de grond daarna in principe weer gebruikt kan worden als landbouwgrond. In de praktijk blijkt echter vaak wel een bestemmingswijziging plaats te vinden. Het is ook de vraag in hoeverre het werkelijk tijdelijk is. (https://www.boerderij.nl/Home/Achtergrond/2018/11/Wijzigt-de-bestemming-bij-aanleg-zonnepark357403E/)

Fiscaal is meestal wel sprake van een verandering van de status van de grond. De landbouwvrijstelling vervalt voor de grond waarop de panelen komen. Voor toepassing van de landbouwvrijstelling (een belastingregel die bepaalt dat de mogelijke waardevermeerdering van landbouwgrond bij voortgezet agrarisch gebruik niet wordt meegeteld bij de bepaling van de inkomstenbelasting) is het nodig dat de grond (nagenoeg geheel) voor landbouw in gebruik is. Bij de plaatsing van zonnepanelen is dat niet het geval, ook niet als er wat vee onder graast, om de begroeiing kort te houden.

(https://www.boerderij.nl/Home/Achtergrond/2018/10/Geldt-landbouwvrijstelling-nog-bij-eenzonnepark-348900E/)

Eigenaren van gronden bestemd voor een zonnepark die binnen een landgoed onder de Natuurschoonwet liggen, kunnen te maken krijgen met een naheffing van de belastingdienst.

\subsection{Locatiekeuze van zonneparken}

In heel Nederland zijn er veel initiatieven voor nieuwe zonneparken. In het verspreidingsgebied van de Stentor bijvoorbeeld (Overijssel en half-Gelderland), gaat het in november 2018 om 50 nieuwe parken, van 1 tot meer dan 20 ha per park; 15 plannen gaan om parken groter dan 20 ha, in totaal gaat het om 723 ha. Gemeenten zijn vaak positief - ze willen hun duurzaamheidsambitie realiseren, maar omwonenden vrezen verandering van het landschap en verlies van uitzicht: de panelen gaan tot $3 \mathrm{~m}$ of meer de hoogte in.

(https://www.destentor.nl/raalte/oost-nederland-werkt-aan-50-nieuwe-zonneparken-invasie-van-deenergiecowboys ab3ca9c3/)

Ontwikkelaars van zonneparken werken stapsgewijs:

- Biedt het provinciale en gemeentelijke beleid ruimte voor zonneparken?

- Op welke plekken is een (goedkope) aansluiting op het elektriciteitsnet mogelijk?

- Op die plekken gaan ze in gesprek met grondeigenaren, vaak agrariërs.

- In de huidige situatie worden pachtprijzen geboden van 4000-8000 euro per ha per jaar. Bij een park van 20 ha gaat het om ruim een ton aan inkomsten voor de landeigenaar, waarvoor nauwelijks iets hoeft te worden gedaan. Dit is voor boeren die willen stoppen of afbouwen een zeer aanlokkelijk perspectief.

LTO Noord - regio Oost is niet blij met deze ontwikkeling: het levert een versnipperd landschap op en jonge boeren worden belemmerd in hun mogelijkheden voor bedrijfsontwikkeling, doordat gronden bestemd voor zonneparken niet meer beschikbaar zijn voor de overblijvende landbouwbedrijven.

Hoogleraar zonne-energie, Wim Sinke, geeft aan dat het belangrijk is om niet alleen naar 'traditionele' zonneparken te kijken, maar ook naar andere oppervlakten, zoals:

- Gebouwen

- Wegen

- Spoorlijnen

- Bedrijventerreinen 


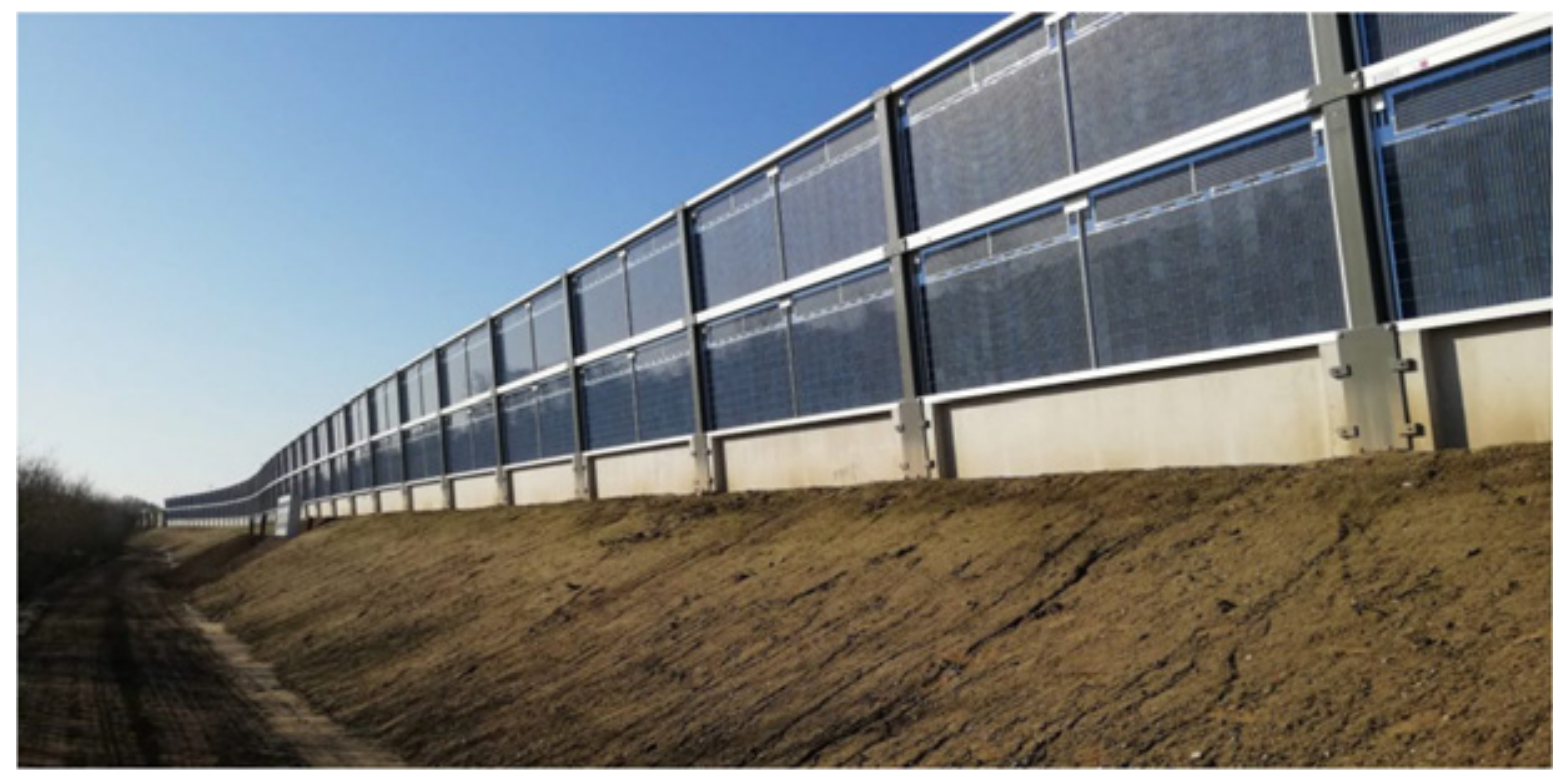

Figuur 5 Bifaciale panelen langs de A50 bij Uden, geluidswal en zonne-energie gecombineerd. Foto: Solar Energy Application Centre (Bron: PV Magazine 20/2/2019).

De huidige SDE+-regeling werkt grote parken met maximale schaalvoordelen in de hand: voor dergelijke parken kan snel worden ingeschreven met het laagste subsidiebedrag. Sinke geeft aan dat een betere integratie van zonneparken met de omgeving gewenst is.

Vooral bij de grotere parken (meer dan 20 ha) ontstaat er veel verzet in de omgeving. Argumenten zijn de massaliteit, slechte communicatie en boosheid dat winsten en subsidiegelden bij grote, soms buitenlandse bedrijven terechtkomen, terwijl de streek 25-30 jaar zit opgescheept met een zonnepark. De grote ontwikkelaars geven aan dat zij wel in gesprek gaan met de buurt en dat er ook mogelijkheden zijn voor omwonenden om financieel deel te nemen.

Maar, zoals ook bleek uit het voorbeeld van Wierden, het kan ook anders: het zonnepark Heeten is eigendom van een coöperatie van Heetenaren, de omvang is 3,5 hectare en de winst wordt besteed in het dorp. Hoogleraar Sinke geeft ook aan dat het beter is om te streven naar kleine projecten met draagvlak dan naar grote projecten die weliswaar zorgen voor grote stappen, maar het fundament onder het draagvlak voor de energietransitie wegslaan.

Uiteindelijk zijn het de gemeenten die bepalen of een aanvraag voor een zonnepark een vergunning krijgt. Zij kunnen voorwaarden stellen met betrekking tot locaties, participatie, omvang en inpassing. Zo zijn bij de gemeente Ede tot het najaar van 2018 in totaal 25 initiatieven voor zonneparken gemeld, waarbij de gemeente voorlopig alleen wil kijken naar de mogelijkheden voor zonneparken van Wageningen UR langs de Langesteeg in Bennekom (10 ha) en van de Coöperatie Vallei Energie op de geluidswal langs de A12 bij Cinemec. De gemeente Ede wil het plan van Wageningen UR gebruiken om ervaring op te doen, waarmee andere initiatieven beoordeeld kunnen worden. Ook is de voorwaarde gesteld dat Wageningen UR het effect van het zonnepark op de bodemkwaliteit moet onderzoeken en zo nodig beperken. Er is door de gemeente Ede een doelstelling geformuleerd van 50 ha in 2022. Op korte termijn wil de gemeente Ede een uitnodigingskader ontwikkelen, waarna verdergaande besluitvorming kan plaatsvinden. 


\subsection{Monitoring van het areaal zonneparken}

Het CBS houdt statistieken bij van hernieuwbare energie, waaronder zonne-energie.

(https://www.cbs.nl/nl-nl/onze-

diensten/methoden/onderzoeksomschrijvingen/aanvullende\%20onderzoeksbeschrijvingen/zonnestroom)

Het CBS probeert via een enquête zo goed mogelijk alle leveranciers in beeld te krijgen en vraagt hun naar het geïnstalleerd vermogen. Om vervolgens een uitsplitsing naar sector of regio te maken, maakt CBS gebruik van de Energie-investeringsaftrekregeling (EIA) en CertiQ-data over zonnepanelen bij bedrijven. Zonnepanelen bij woningen worden volgens deze methode bepaald als de restpost. Ook is gebruikgemaakt van een bestand van de belastingdienst met aangiften voor btw-aftrek voor zonnepanelen. Hieruit blijkt dat in 2017 voor 376 MW (31\%) aan zonnepanelen staat opgesteld bij bedrijven in landbouw, bosbouw en visserij op een totaal van $1221 \mathrm{MW}$ bij 53.000 bedrijven. Bij in totaal 516.000 woningen stond in $20171652 \mathrm{MW}$ aan zonnepanelen opgesteld. Bij de CBS-registratie wordt geen onderscheid gemaakt tussen zonnepanelen op daken en zonnepanelen in zonneparken.

RVO publiceert de SDE- en SDE+-subsidies in een lijst en op een kaart; hierbij worden gegevens van particulieren, vof's en maatschappen die tot personen herleidbaar zijn, geanonimiseerd. Bij de kaartweergave wordt niet de exacte locatie van de panelen gebruikt, maar het postcodegebied (alleen cijfers) van de aanvrager. Na goedkeuring van de aanvraag heeft de aanvrager vier jaar de tijd om het project te ontwikkelen. (Bron: https://www.rvo.nl/subsidies-regelingen/stimulering-duurzameenergieproductie/feiten-en-cijfers/feiten-en-cijfers-sde-algemeen.)

Om de ontwikkeling van zonneparken te monitoren, zou ook gebruikgemaakt kunnen worden van satellietbeelden en luchtfoto's, waar via een automatisch proces zonnepanelen herkend kunnen worden. Daarbij is het nodig om een koppeling te maken met een hoogte- en/of gebouwenbestand, zodat daarmee onderscheid gemaakt kan worden tussen panelen op daken en zonneparken op de grond (of op het water). Dit moet nog ontwikkeld worden. Tot nu toe zijn er alleen pilotprojecten geweest.

De figuur hieronder geeft de ontwikkeling van het SDE+-subsidieverplichtingenbudget van de afgelopen jaren. Het aandeel zonne-energie is in 2017 en 2018 flink toegenomen. In bv. Gelderland zijn in 20171081 aanvragen toegekend; veel aanvragen hiervan betreffen een vermogen van minder dan $1 \mathrm{MWh}$. In het overzicht kan helaas geen onderscheid gemaakt worden tussen zonnepanelen op daken en zonneparken op de grond of op het water. In de voorjaarsronde van 2018 zijn 3899 SDE+subsidieaanvragen goedgekeurd. Het merendeel hiervan betreft zonne-energie. Inmiddels zijn echter in de meeste noordelijke provincies de grenzen van het netwerk bereikt, en is daar op het huidige netwerk geen ruimte meer om de stroom van nieuwe parken af te nemen. Verzwaring van het net kost vijf tot tien jaar. 


\section{Verplichtingenbudget}

\section{per technologie in de verschillende SDE+-rondes}
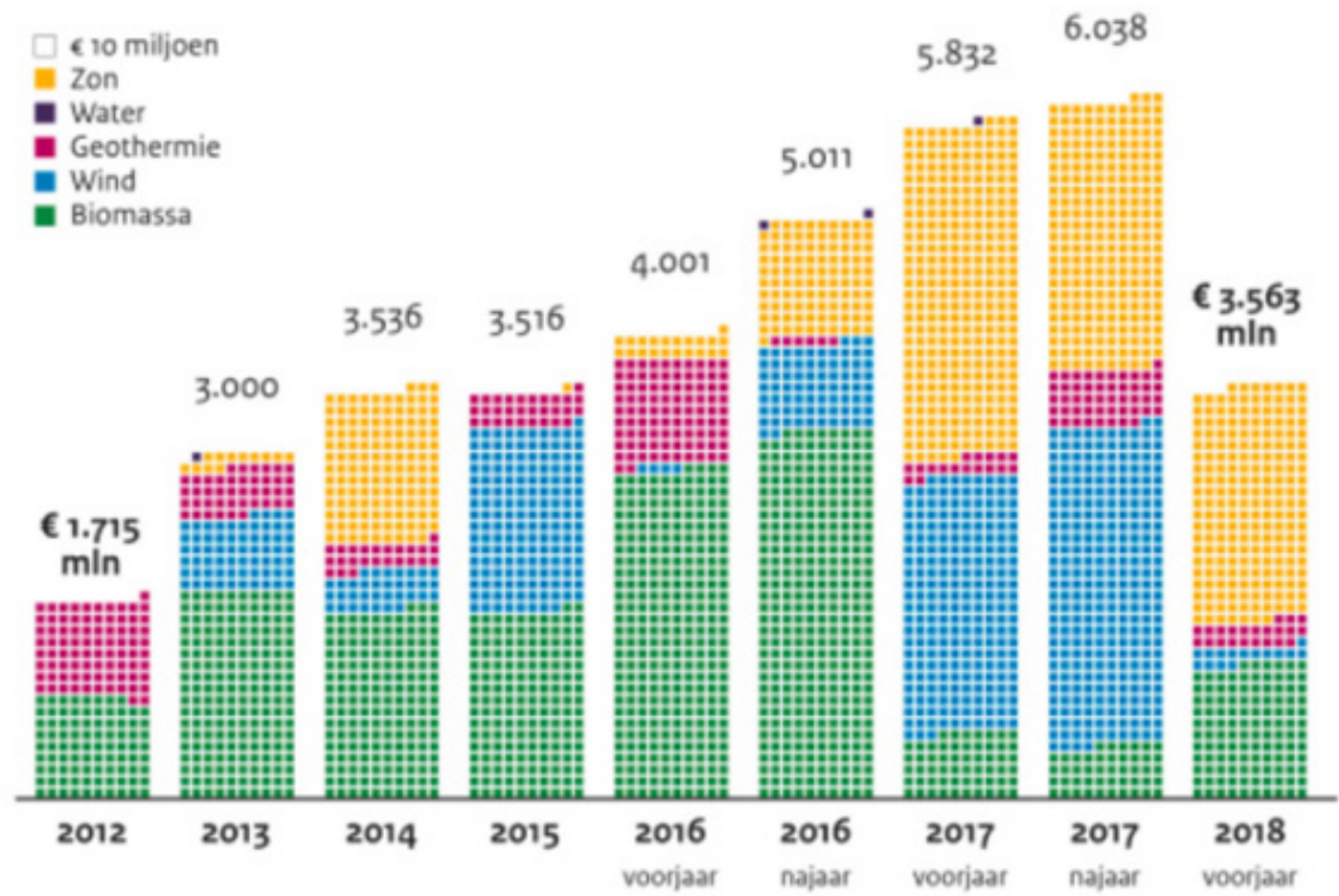

Figuur 6 Ontwikkeling van het SDE+ subsidieverplichtingenbudget.

Op basis van de informatie van RVO heeft ROM3D een overzichtskaart gemaakt met alle zonneparken: http://zonopkaart.nl/. Daarbij wordt ook gemeld of een project is gerealiseerd; het is momenteel bijgewerkt tot en met 2017. De plannen van Wageningen UR zijn hierin bv. nog niet zichtbaar. Hieronder een voorbeelduitsnede.

\section{ZON OP KAART}

KAART STATISTIEKEN STAPPENPLAN QUICKSCAN CONTACT

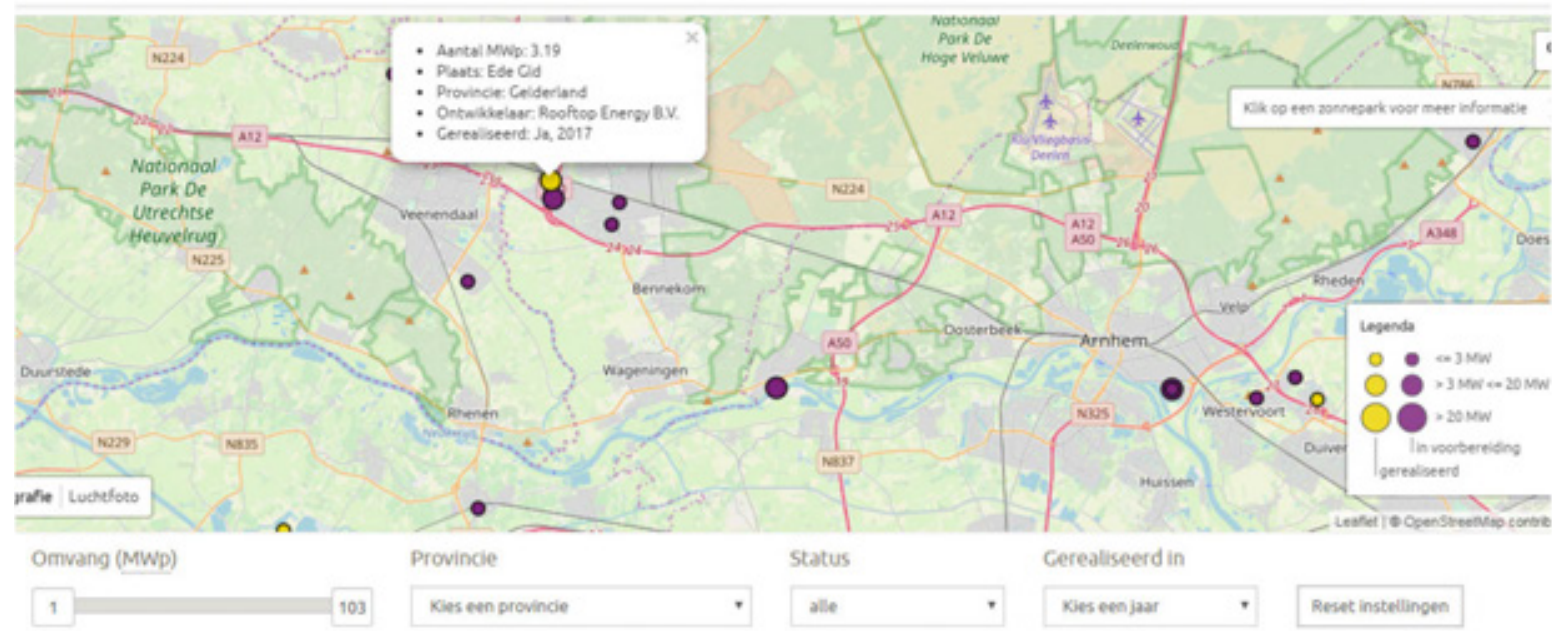

Figur 7 Voorbeelduitsnede overzichtskaart zonneparken.

In de jaarlijkse landbouwtelling worden eenmaal per drie tot vier jaar vragen gesteld over de verbrede ontwikkeling van landbouwbedrijven. De laatste keer was in 2016. Helaas is hierin geen onderscheid gemaakt in het type energieproductie in geval de productie van duurzame energie wordt genoemd. 
Wellicht kan bij de volgende vraagstelling, die waarschijnlijk in 2020 zal plaatsvinden, gevraagd worden naar de bron (zon, wind, vergisting etc.).

\subsection{Conclusies en kennisleemten}

- Zonnestroom en de aanleg van zonneparken maken een sterke groei door. In 2018 is het geïnstalleerde zonnevermogen met $46 \%$ toegenomen. Het areaal zonneparken op de grond groeit sneller dan de oppervlakte zonnepanelen op daken.

- Het realiseren van een zonnepark is een ingrijpend veranderingsproces: zowel wat betreft bestemming als fiscaal gaat het vaak om een omslag van landbouw naar energieproductie. Voor omwonenden lijkt het vaak ook een (te) grote verandering, waarvoor meer draagvlak kan ontstaan als ook sprake is van meer betrokkenheid.

- De realisatie van doelstellingen voor duurzame energie kan op gespannen voet staan met de belangen van de landbouw en de kwaliteiten van het landschap voor natuur en recreatie. De ruimtelijke inpassing is een uitdaging voor gemeenten: zoeken naar een goede balans tussen investeringskosten, omvang van parken, inpassing in het landschap en participatie van bewoners. Het gaat voor de gemeente om de balans tussen de hoeveelheid op te wekken duurzame energie, de schaal waarop, de mate van integratie enerzijds en de kwaliteit van het grondgebied voor diverse functies anderzijds.

- De monitoring van de ontwikkeling van opgewekte zonne-energie en verstrekte subsidies worden door CBS en RVO gerealiseerd; voor de selectie van het aandeel zonneparken daarin is een aanvullende inspanning nodig. Verder kan een automatische detectie van zonneparken via een GISanalyse van satellietbeelden gerealiseerd worden.

- De kennis over de effecten van zonneparken is nog beperkt. Daarom lijkt het aan te bevelen om nader onderzoek te doen, bijvoorbeeld: A) bij de WUR-projecten voor zonneparken (Haarweg Wageningen, Binnenveld - Bennekom en Accres - Lelystad) m.b.v. relevante proefopstellingen. B) Monitoring van pilotprojecten door een ervaringenbank op te richten, bij voorkeur via een website, zodat men deze actueel kan houden. C) Een automatische procedure voor monitoring van zonneparken op basis van satellietbeelden. 


\section{De bodem onder zonnepanelen}

\subsection{Functies van de bodem}

De bodem is de bovenste laag van de aardkorst, maar de definitie in de bodemkunde is specifieker, namelijk die laag van de aardkorst die door planten beworteld wordt (de rhizosfeer), of waarin zich bodemvormende processen afspelen. Een gezonde bodem is een levende bodem waarin natuurlijke processen en functies onbelemmerd kunnen verlopen. Functies die direct of indirect nuttig zijn voor de mens worden ecosysteemdiensten genoemd (figuur 8, rechterkolom) en zijn rechtstreeks gekoppeld aan diverse functies van de bodem. Vaak worden de begrippen functies en diensten door elkaar gebruikt. Belangrijke functies zijn o.a. de omzetting en levering van nutriënten, vorming en instandhouding van bodemstructuur, waterregulatie (infiltratie en vasthouden), onderdrukking van plantenziekten en koolstofvastlegging.

\section{Soil threats}

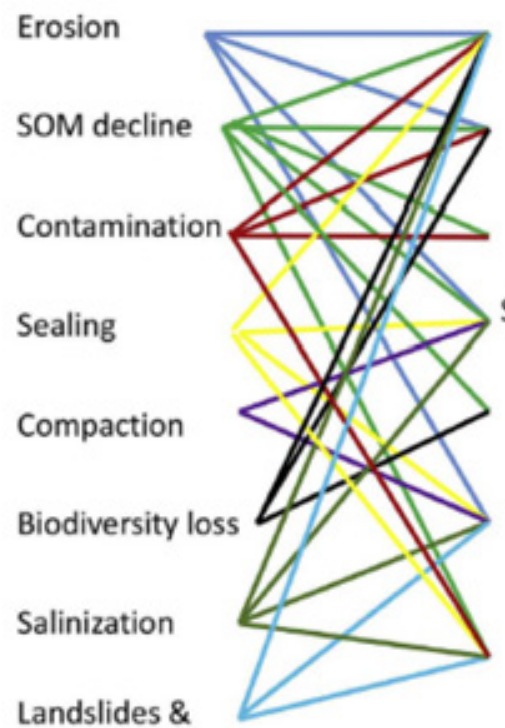
floods
Soil functions, i.e. (bundles of) soil processes

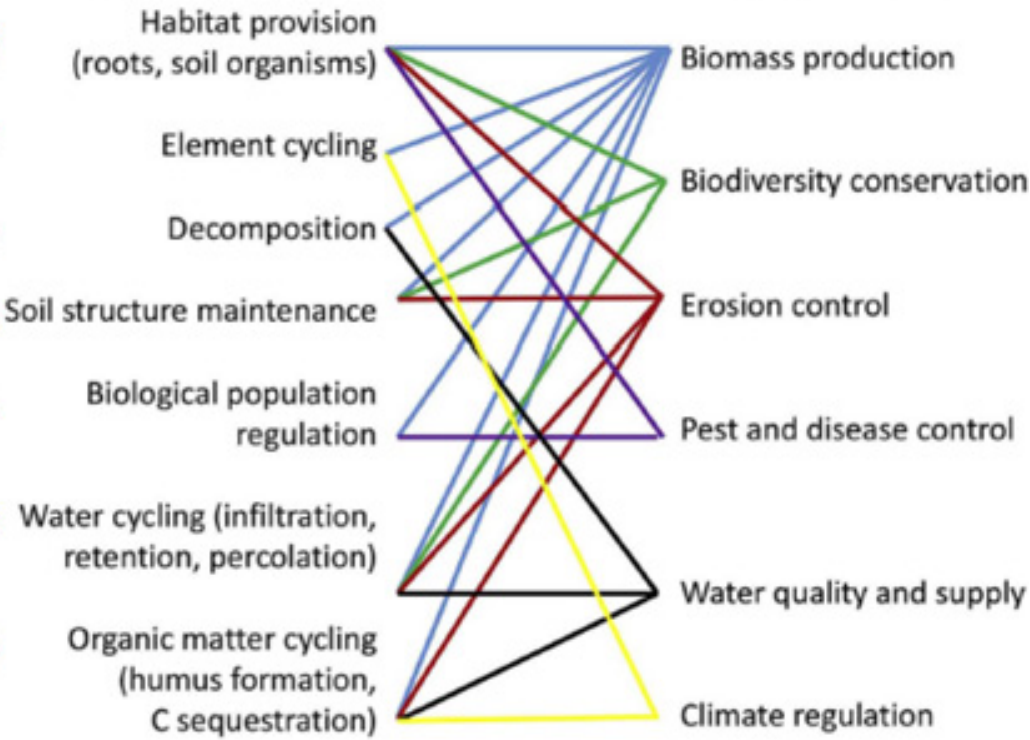

Figuur 8 De relatie tussen bodembedreigingen, bodemfuncties en bodem-ecosysteemdiensten (uit Bünemann et al., 2018).

Voor al deze functies is het bodemleven van groot belang, in samenhang met de fysische en chemische omstandigheden. De vervulling van deze diensten heeft vaak geen direct zichtbare economische betekenis en komt nogal eens in het nauw. In de Europese Bodemstrategie zijn acht bedreigingen voor het functioneren van de bodem beschreven (zie ook figuur 8). Deze omvatten:

- Erosie

- Verlies van organische stof

- Plaatselijke en diffuse bodemverontreiniging

- Bodemafdekking en bodemverdichting

- Afname van de biodiversiteit in de bodem

- Verzilting

- Overstromingen en aardverschuivingen

Verzuring werd in een later stadium aan het rijtje toegevoegd (Rutgers et al., 2011, 2014).

De meeste bedreigingen spelen ook in Nederland. Bodemerosie is in Nederland regionaal een probleem en beperkt zich tot akkerland. Wegspoelen van vruchtbare bovengrond treedt vooral op in 
de lössgebieden in het heuvelland van Zuid-Limburg. Wegwaaien zien we vooral in de veenkoloniën in Drenthe en Groningen, op de zandgronden van Noord-Brabant en Drenthe en in de Bollenstreek

(Hessel et al., 2011). Door intensieve landbouw zijn er serieuze zorgen over bodemverdichting, verlies van organische stof en afname van bodembiodiversiteit (Rutgers et al., 2011, Schouten et al., 2018). In veel natuurgebieden, met name op droge zandgrond, zorgt verzuring voor afname van bodemleven en haperende strooiselafbraak en nutriëntenlevering (Bergsma et al., 2018).

\subsection{De levende bodem}

Een vruchtbare bodem is rijk aan organische stof, houdt water goed vast en bevat veel voedingsstoffen voor planten. Hoe vruchtbaarder de grond, hoe beter we gewassen kunnen produceren als voedsel voor mensen en dieren. Bodemvruchtbaarheid omvat alle chemische, fysische en biologische bodemeigenschappen die nodig zijn voor de groei van planten. In de landbouw draait het erom dat planten zo efficiënt mogelijk hun voedingsstoffen kunnen vinden en opnemen. Tegelijkertijd mogen zo weinig mogelijk voedingsstoffen verloren gaan naar lucht, water of diepere bodemlagen, waar ze onbereikbaar worden voor de plantenwortels.

Een gezonde bodem voor de landbouw is niet per definitie het beste voor behoud van de biodiversiteit aan wilde planten en de insecten en vogels die daarvan profiteren. In de gangbare landbouw blijft door intensieve grondbewerking, bemesting en chemische bestrijding van ongewenste organismen weinig ruimte over voor natuurwaarden. Enkele decennia geleden was er veel meer ruimte voor wilde planten, insecten, zoogdieren en vogels. Het natuurbeleid en -beheer in Nederland streeft ernaar zo veel mogelijk van die soorten verbonden aan het oude soortenrijke (biodiverse) cultuurlandschap te behouden. Een minder intensief bewerkte bodem (minder intensieve landbouw) of een bodem die een tijd met rust wordt gelaten (braaklegging - geen landbouw), zal meer waarde voor de natuur ontwikkelen.

Fysische bodemvruchtbaarheid omvat de structuureigenschappen van de bodem. Deze moet een kruimelige structuur bieden waarin plantenwortels vocht en voedingsstoffen kunnen opnemen. Ook moet de grond blijven liggen waar die ligt. Dus niet bij de eerste de beste regenbui wegspoelen, of met de wind wegwaaien (erosie). De eigenschappen van een bodem zijn onder andere afhankelijk van de textuur, oftewel de korrelgrootteverdeling van een bodem. Kleigronden bevatten relatief veel deeltjes die kleiner zijn dan 2 micrometer. Zandgronden bevatten vooral deeltjes groter dan 64 micrometer. Vanwege de vele kleine poriën in kleigrond wordt organische stof meer beschermd tegen afbraak. In zandgrond wordt organische stof sneller afgebroken dan in kleigrond. Weliswaar wordt organische stof bij hogere $\mathrm{pH}$ sneller afgebroken en heeft kleigrond een hogere $\mathrm{pH}$ dan zandgrond, maar het effect van het verschil in korrelgrootte is sterker. De textuur is, samen met het gehalte aan organische stof, belangrijk voor het vochthoudend vermogen, maar ook voor de kans op verdichting, erosie en verslemping. Omdat bodemaggregaten (kruimels) de neiging hebben uit elkaar te vallen, met name door regen, is een actief bodemleven nodig. Plantenwortels en schimmeldraden vormen netwerken die bodemdeeltjes bij elkaar houden, en schimmels en bacteriën maken slijm waarmee aggregaten aan elkaar plakken. Ook bodemdieren, met name regenwormen, spelen een rol bij het in stand houden van een kruimelige bodemstructuur waardoor water beter wordt vastgehouden. Daarnaast maken sommige wormen verticale gangen die de waterinfiltratie (wegzijging) verbeteren.

De biologische bodemvruchtbaarheid heeft betrekking op de rol van de levende organismen (figuur 9). In de bodem leven micro-organismen, zoals bacteriën en schimmels, en fauna, zoals protozoën, nematoden (aaltjes), mijten, springstaarten en regenwormen. Al deze organismen zijn op de een of andere manier betrokken in de nutriëntenkringloop in de bodem. Het is eten en gegeten worden. Ze voeden zich met plantenresten, met organische mest, maar ook met elkaar. Een deel van het verwerkte voedsel komt weer beschikbaar als voedingsstoffen voor de plant. Een ander deel wordt vastgelegd in het weefsel van de organismen zelf of in andere vormen van organische stof (dode resten) en afbraakproducten (humus). 


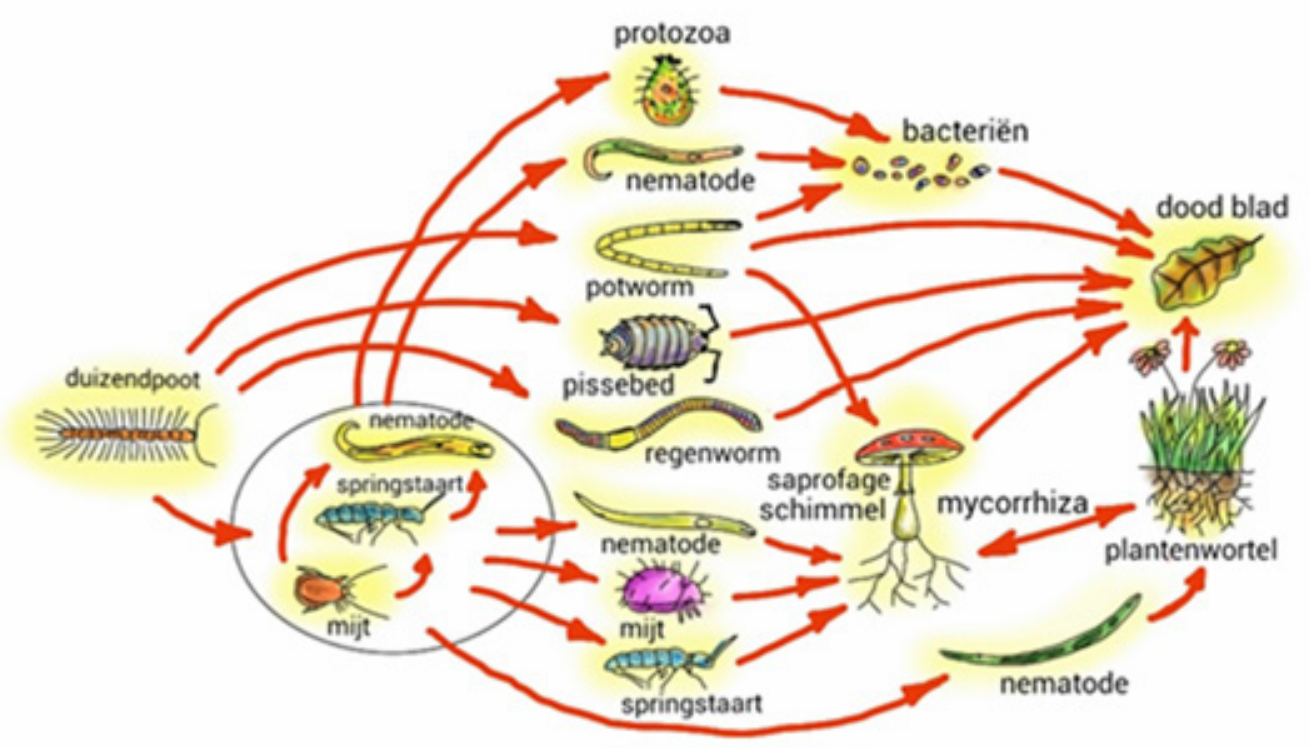

Figuur 9 Bodemvoedselweb (Ron de Goede, WUR, uit Rutgers et al. 2018).

Organische stof vervult een sleutelrol in de bodem. De meeste organische stof op of in de bodem is primair afkomstig van plantengroei. De plantengroei is, behalve van bodemvruchtbaarheid en water, afhankelijk van licht. De mate waarin zonnepanelen door hun schaduwwerking de plantengroei belemmeren, bepaalt dus de productie van organische stof en daardoor de omvang en samenstelling van het bodemvoedselweb.

Licht en water hebben dus een grote invloed op de bodemkwaliteit. Een volledig beschaduwde bodem die geen licht krijgt en die ook niet bewaterd wordt door regenwater, zal 'afsterven'. Daarnaast zijn voldoende licht en water belangrijk voor de plantengroei. Op plaatsen waar weinig licht en regenwater valt, ontwikkelt de vegetatie zich slechter.

\subsection{Effecten van zonneparken op bodem en bodembiodiversiteit}

Op basis van de weinig beschikbare wetenschappelijke studies wordt verondersteld dat zonneparken een negatieve impact kunnen hebben op de biodiversiteit, bodemkwaliteit en interactie $\left(\mathrm{CO}_{2}\right.$-fluxen) tussen bodem en atmosfeer (Kok et al., 2017). Het lokale en microklimaat en de opbouw van organisch materiaal door planten met behulp van fotosynthese (primaire productie) zullen veranderen door afdekking van de bodem, verminderde lichtinval en veranderde neerslagverdeling. Veel minder direct en indirect (diffuus) licht bereikt de vegetatie, zowel onder als tussen de zonnepaneelrijen. Onderzoekers in Lancaster hebben een $50 \%$ tot meer dan $90 \%$ lagere fotosynthese gemeten bij gras onder zonnepanelen van een drie jaar oud zonnepark (Armstrong et al., 2016). Minder fotosynthese resulteert in een geringere primaire productie en leidt tot een lagere input van vers organisch materiaal in de bodem. Onder de panelen was de soortenrijkdom van de planten de helft lager en was de bovengrondse biomassa 75\% lager dan tussen en buiten de panelen (controle). Desondanks was de microbiële biomassa in de bodem na drie jaar (nog?) niet lager onder de panelen. In tegenstelling tot de verwachting was ook het gemiddelde vochtgehalte in de bodem niet verschillend, waarschijnlijk omdat er wel water langs het frame tussen de panelen loopt. Waar neerslag geconcentreerd op de bodem terechtkomt als gevolg van de opstelling van de panelen, zal uitloging plaats kunnen vinden. Het gegalvaniseerde rek zal tot enige metaalbelasting van de bodem kunnen leiden. De mate waarin dit optreedt, hangt vooral af van de oppervlakte verzinkt staal waar regelmatig regenwater langs afstroomt. Dit hangt dus af van de constructie van de zonnetafel. Ook veranderde de lokale temperatuur: van het voorjaar tot het najaar was de bodem onder de zonnepanelen gemiddeld $5,2{ }^{\circ} \mathrm{C}$ koeler. Lagere temperaturen in het groeiseizoen hebben waarschijnlijk effect op vele, belangrijke 
plant- en bodemprocessen waaronder biomassaproductie en afbraak van organische stof. Hoewel de verschillen niet altijd statistisch significant waren, was er wel een tendens dat onder de panelen netto meer $\mathrm{CO}_{2}$ vrijkwam (source), terwijl tussen en buiten de panelen netto meer $\mathrm{CO}_{2}$ werd vastgelegd (sink). Er zijn aanwijzingen dat dit samenhangt met de eigenschappen van de vegetatie en dat korte termijn-vegetatiebeheer de koolstofkringloop in zonneparken kan beïnvloeden. De publicatie vermeldt niet hoe hoog de zonnetafels in hun onderzoek waren, wel de breedte: 4,4 m. De vier monsterpunten onder de zonnetafel zijn random gekozen. De hoeveelheid voor plantengroei beschikbaar licht neemt af van de rand van de tafel naar het midden en is sterk afhankelijk van de hoogte van de op het zuiden gerichte zonnetafel. Het is dus volstrekt onbekend hoe representatief de metingen zijn voor de in Nederland gerealiseerde zonneparken. Theoretisch is netto-opslag van $\mathrm{CO}_{2}$ in een zonnepark mogelijk indien er voldoende vegetatie groeit onder de panelen en deze niet wordt afgevoerd.

Een ecologische inrichting van zonneparken met extensief beheerde vegetaties als uitgangspunt kan ook kansen bieden op een positief effect op de structuur en kwaliteit van de bodem, vooral als de uitgangssituatie intensieve landbouwgrond was (Klaassen et al., 2018). De verwachte levensduur van zonneparken is ten minste vijftien en mogelijk wel dertig jaar. Omdat de grond voor lange tijd uit productie genomen wordt, kan de grond tot rust komen en de bodemkwaliteit herstellen en verbeteren. Specifieke aandachtspunten zijn het voorkomen van bodemverdichting tijdens de aanleg van zonneparken en het voorkomen van vervuiling van de bodem met zink door (de wijze van) gebruik van verzinkte palen voor zonnetafelconstructies. Erosie en uitspoeling kunnen een issue zijn als panelen vrij vlak en dicht aaneengesloten in de tafels liggen en de ruimte tussen rijen panelen nauw is (slechte ontwikkeling van de vegetatie) en in het geval het zonnepark op een helling gebouwd is.

Vegetatie onder panelen ontwikkelt zich slechter naarmate een groter deel van het voor de fotosynthese bruikbare directe en diffuse licht wordt tegengehouden (Beatty et al., 2017; Dupraz et al., 2011; Fraunhofer Institute, 2017; Kok et al., 2017; Majumdar et al., 2018; Valle et al., 2017). De mate waarin dit gebeurt, is afhankelijk van de eigenschappen van het zonnepark. Een zonnepark bestaat uit 'tafels', waarin een groot aantal panelen zijn samengevoegd tot één geheel. Een zonnetafel (solar array) heeft een lengte, een breedte, een minimum- en maximumhoogte die de hellingshoek bepalen en een oriëntatierichting op de zon (expositie). Binnen de zonnetafel zijn er horizontale en verticale spleten tussen de afzonderlijke panelen van meestal 1 à $2 \mathrm{~cm}$ breed die licht en regenwater doorlaten. Ze kunnen geheel of gedeeltelijk voorkomen dat regenwater helemaal afstroomt naar de onderrand van de tafel. Al deze eigenschappen bepalen mede hoeveel licht en regenwater er op de bodem onder de tafels valt en daarmee in welke mate vegetatiegroei hierdoor wordt beperkt. Met simulatiemodellen is voor gespecificeerde opstellingen te berekenen hoe groot de lichtreductie over het groeiseizoen of op een bepaald moment van het seizoen of de dag zal zijn. In figuur 10 is een dergelijke simulatie weergegeven voor zonnepanelen die op een hoogte van $4 \mathrm{~m}$ boven het maaiveld zijn geïnstalleerd in twee verschillende dichtheden. Het plaatje laat de totale hoeveelheid direct zonlicht zien die jaarlijks op de bodem onder de panelen valt. Alleen de bodem direct onder de panelen is hier weergegeven. 


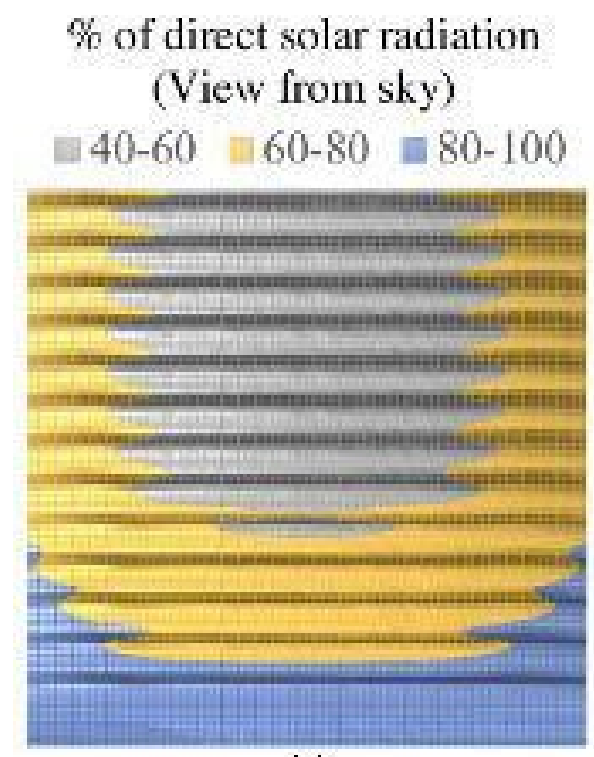

(j)

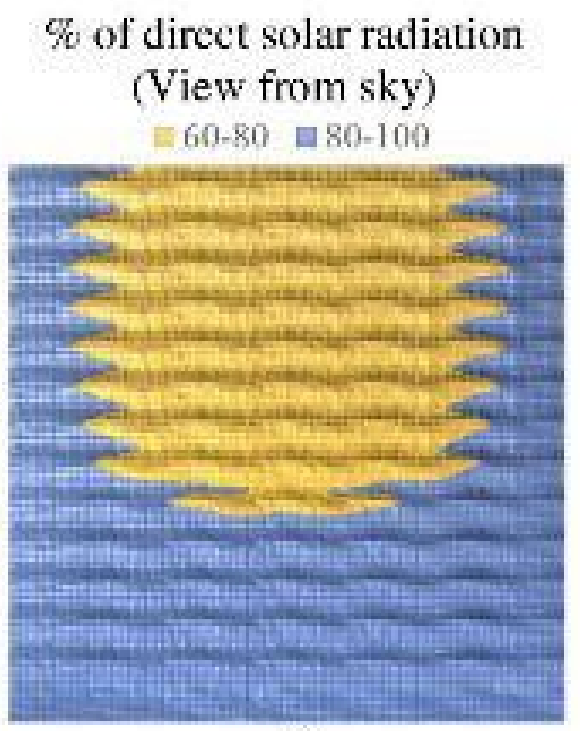

(hi)

Figuur 10 Gemodelleerde zonlicht reductie in op het zuiden gerichte panelen; waarbij de tafels de helft (a) of een kwart van de bodem bedekken (naar Majumdar \& Pasqualetti, 2018, overgenomen uit Frambach et al. 2018).

Er bestaat geen overzicht van de eigenschappen van de Nederlandse zonneparken en er zijn geen metingen bekend van de hoeveelheid regenwater en licht onder de zonnetafels. Er zijn slechts enkele publicaties gevonden met meetwaarden onder zonnepanelen (Dupraz et al., 2011; Armstrong et al., 2016; Fraunhofer Institute, 2017). Het diffuse licht nam af tot ongeveer $60 \%$. In een systeem met een halve dichtheid aan panelen was de hoeveelheid licht onder panelen van $1 \mathrm{~m}$ hoogte $55 \%$ tot $85 \%$. Onder hoge zonnepanelen is de lichtreductie veel minder. Er zijn gewasopbrengsten mogelijk die slechts 5\% (grasklaver mengsel) en 18 tot 19\% (aardappels, tarwe) lager zijn dan op een normale akker (Fraunhofer Institute, 2017). In Estland zijn proeven gedaan met kunstmatige beschaduwing van 46 soorten grassen en graslandplanten (Semchenko et al., 2012). Deze studie laat zien dat veel planten een groot aanpassingsvermogen hebben en dat de soorten verschillend reageren. Er zijn veel schaduwminnende planten die juist profiteren van beschaduwing. Bij een beschaduwing tot $50 \%$ van het daglicht nam de drogestofproductie zelfs toe, bij $25 \%$ van het daglicht was er nog geen significante afname en pas bij $10 \%$ of minder was de vegetatiegroei echt geringer. Eventuele gunstige effecten van schaduw zullen afhangen van het heersende klimaat en mogelijk groter zijn in warmere streken met meer zonlicht.

In een recent studentenonderzoek (Frambach et al., 2018) in Nederland is op zonnige dagen de relatieve hoeveelheid licht (PAR, photosynthetic active radiation) gemeten onder zonnepanelen in vier op het zuiden gerichte zonneparken (hoogte minimaal 50-70 cm maximaal 220-245 cm, helling 16 tot 21 graden, breedte van de tafels 4 tot $6 \mathrm{~m}$ en de breedte tussen de rijen 4,6 tot $6 \mathrm{~m}$ ). Aan de randen van de tafels was de relatieve reductie van de hoeveelheid licht op bodemhoogte $58 \%$ tot $82 \%$, in het midden 89 tot $95 \%$. Een algemene observatie was dat er midden onder de tafels meestal minder vegetatie was, bestaand uit evenveel maar andere soorten. In de schaduw stonden duidelijk minder bloeiende planten dan in volle zon. Deze vanwege het geringe aantal waarnemingen niet toetsbare observatie geeft een eerste indruk. Er kunnen geen harde conclusies aan worden verbonden. Bovendien is in september-oktober 2018 in de vier zonneparken gekeken naar de diversiteit en abundantie van regenwormen (Frambach et al., 2018). De uitkomst was dat er midden onder de panelen minder wormen werden waargenomen (niet toetsbaar vanwege het beperkt aantal waarnemingen). De observaties wijzen ook op minder bodemactiviteit $\left(\mathrm{CO}_{2}\right.$-productie, bodemademhaling), nattere omstandigheden aan de zuidkant (drup) en drogere omstandigheden (waterinfiltratie) onder de panelen. Tussen de parken zijn er behoorlijke verschillen in de waarnemingen, zodat eenduidige conclusies uit dit onderzoek niet kunnen worden getrokken. 


\subsection{Verwachte effecten op bodem-ecosysteemdiensten}

In Kok et al. (2017) hebben vijf bodemdeskundigen individueel de effecten van zonneparken op elf verschillende bodem-ecosysteemdiensten van grasland geschat (expert judgement) met behulp van impactscores op een relatieve schaal van -2 (negatieve impact) tot +2 (positieve impact) (0: geen impact). Bijna alle gemiddelde scores voor de bodem tussen panelen liggen tussen 0 en - 1 (op één na); alle scores voor de bodem onder panelen liggen tussen -1 en -2 (figuur 11). De verwachting van het effect op bodem-ecosysteemdiensten is voor conventioneel beheerd grasland iets gunstiger dan voor extensief beheerd grasland. Dit komt doordat het met rust laten van de bodem voordelen met zich meebrengt voor de bodemgerelateerde ecosysteemdiensten. Er zal bijvoorbeeld niet meer geploegd worden en het uitblijven van bemesting leidt tot een lagere belasting van grond- en oppervlaktewater met meststoffen (fosfaat en nitraat).

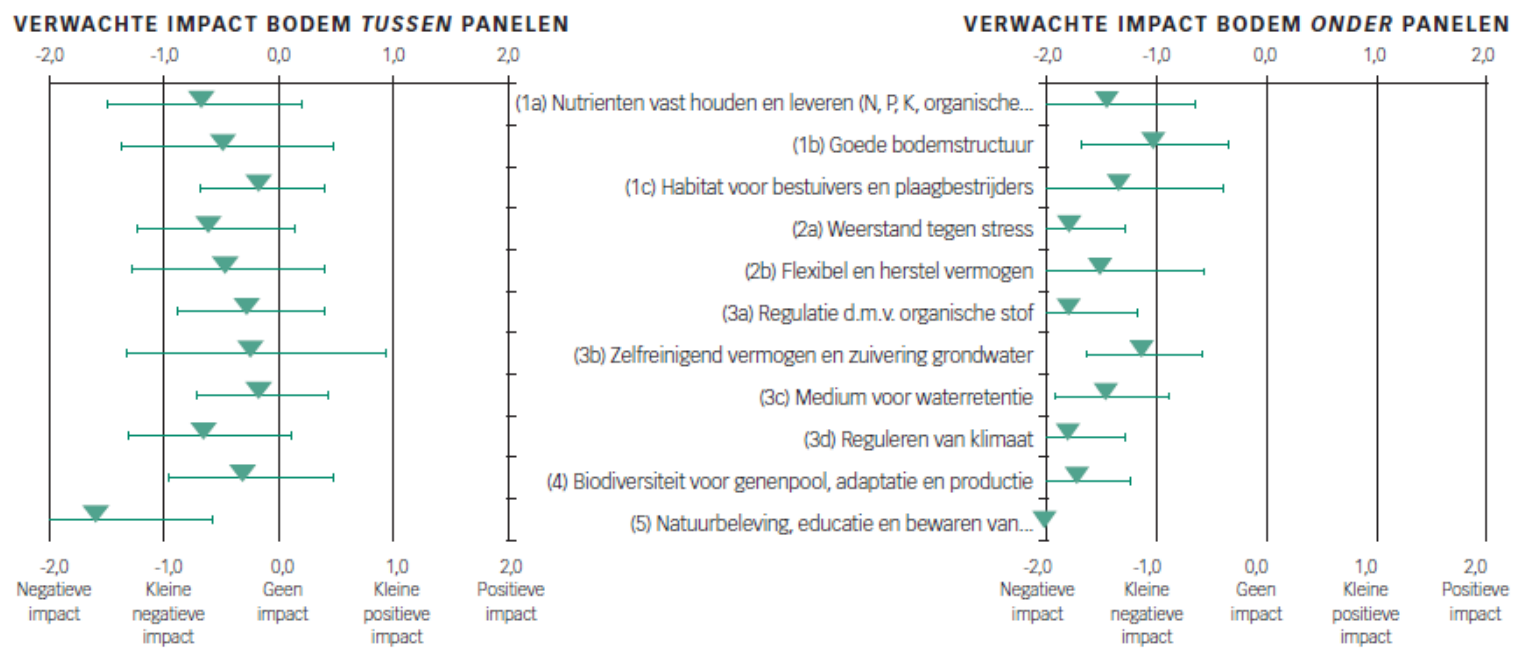

Figuur 11 Gemiddelde scores van vijf deskundigen voor verwachte impact van zonnepanelen op bodem-ecosysteemdiensten tussen en onder de panelen (uit Kok et al., 2017).

Veel van de negatieve scores zijn gebaseerd op een verwachte afname van organische stof in de bodem en primaire productie als gevolg van minder licht en minder regenwater onder de panelen. Waarschijnlijk zijn effecten op organische stof en bodemleven pas na langere tijd merkbaar. Wanneer de zonnepanelen worden verwijderd (na bv. 25 jaar) kan de bodem zich in principe herstellen, maar bodemherstel gaat traag. Er worden dus overwegend negatieve effecten van zonneparken op de bodemgerelateerde ecosysteemdiensten verwacht. Over de mate en ernst van deze effecten is slechts weinig bekend, omdat empirisch onderzoek ernaar vrijwel ontbreekt (Kok et al., 2017).

\subsection{Conclusies en kennisleemten}

Er is vrijwel geen empirische kennis gepubliceerd over effecten van zonneparken op de bodemkwaliteit en het bodemleven. Hier is dus een kennisleemte. Om verder te komen dan expert judgement op basis van aannamen, zijn metingen noodzakelijk. Het beste is om voor de aanleg van een aantal zonneparken een nulmeting uit te voeren aan de bodem en vervolgens minimaal vijf jaar te monitoren wat er met de vegetatie en de bodem gebeurt. Ondertussen zou gestart moeten worden met onderzoek bij bestaande installaties van verschillende leeftijden (minimaal drie jaar) op verschillende locaties.

De voornaamste zorg is dat minder licht en een andere verdeling van het water via minder planten(wortels) zullen leiden tot minder bodemleven, lagere organische stofgehalten en een afname van de bodemvruchtbaarheid. Dit is met name van belang als de grond later weer voor landbouw 
gebruikt zou worden. Zowel opbouw als afname van het organische stofgehalte in de bodem gaat langzaam en kan pas na meer dan tien jaar meetbaar worden. Het bodemleven reageert al binnen drie tot vijf jaar. Dit kan worden gemeten aan de hand van indicatoren voor labiele (gemakkelijk afbreekbare) organische stof en verschillende groepen organismen (Rutgers et al., 2014; Bloem et al., 2017; Schouten et al., 2018). Er zijn referentiewaarden voor verschillende typen bodems uit de Bodembiologische Indicator (Bobi) en het Landelijk Meetnet Bodemkwaliteit. Door vergelijking van waarden onder en voor de panelen en aan de onbereden rand van het veld (ongestoorde grond), kan worden vastgesteld in hoeverre er verschillen zijn in bodemkwaliteit en hoe de waarden zich verhouden tot referentiewaarden van vergelijkbare landbouwgrond en natuurgebieden. 


\section{Consequenties voor de landbouw}

\subsection{Vraag en aanbod landbouwgrond}

\section{Landelijk beeld}

In de landbouw is een jarenlange trend gaande van schaalvergroting. Elk jaar wordt ongeveer $2-3 \%$ van de landbouwbedrijven beëindigd. De jaarlijkse vermindering van landbouwgrond bedraagt ca. $0,3 \%$ per jaar (natuur, infrastructuur en verstedelijking). Dit betekent dat het grootste deel van de landbouwgrond die beschikbaar komt door bedrijfsbeëindiging wordt overgenomen door de blijvende bedrijven, die daardoor steeds groter worden (zie figuur 12 met de ontwikkeling van het aantal landbouwbedrijven en -areaal). Landbouwbedrijven zijn van 1950 tot 2019 ontwikkeld van gemiddeld 500 are ( 5 ha) tot 2500 are (35 ha).

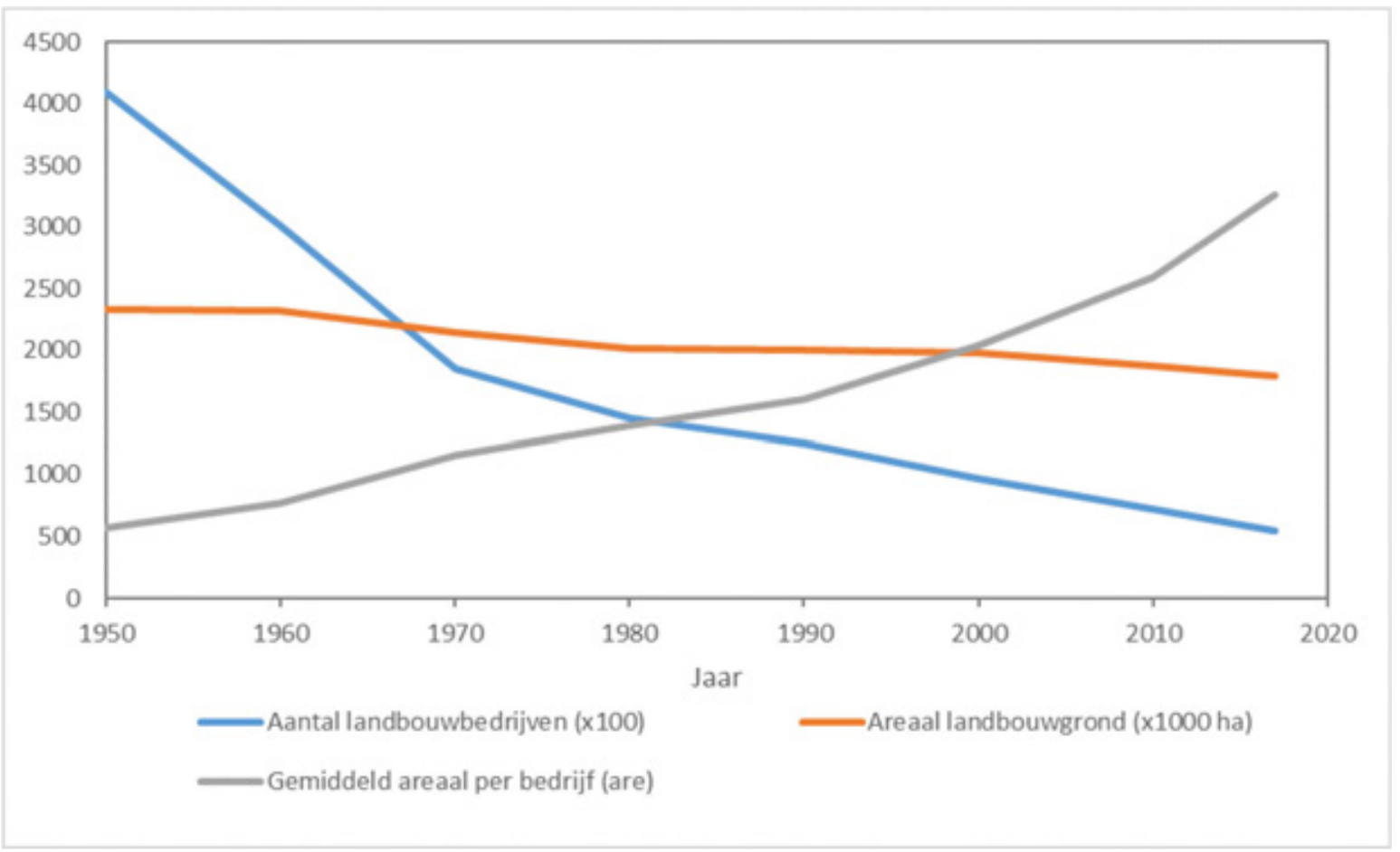

Figuur 12 Ontwikkeling van het aantal landbouwbedrijven en het landbouwareaal (bron: CBS).

De ontwikkelingen in de landbouw van de afgelopen jaren leiden eerder tot een behoefte aan meer grond dan dat grond uit de landbouw beschikbaar zou komen voor bv. zonneparken. Enkele belangrijke ontwikkelingen hierbij zijn:

- Grondgebonden groei melkveehouderij; vanaf 2015 is dit principe als stelsel in werking getreden $(A M v B)$, vanaf 2018 is het als maatregel opgenomen in de Meststoffenwet.

Melkveehouderijbedrijven mogen alleen onder voorwaarden groeien: extra fosfaatproductie door uitbreiding van de melkveestapel moet verwerkt of volledig op eigen grond geplaatst kunnen worden. (https://www.rvo.nl/onderwerpen/agrarisch-ondernemen/mestbeleid/mest/verantwoordegroei-melkveehouderij.)

- Fosfaatrechten voor melkveebedrijven; vanaf 2017 zijn fosfaatreductiemaatregelen doorgevoerd. Vanaf 2018 is het fosfaatrechtenstelsel van kracht geworden. Bij de berekening van de fosfaatrechten van een bedrijf wordt niet alleen rekening gehouden met de referentiesituatie in 2015 (aantal stuks melkvee en melkproductie), maar ook met de fosfaatruimte, die bepaald wordt door de 
vermenigvuldiging van het oppervlak landbouwgrond en natuurterrein in 2015 met de fosfaatgebruiksnormen daarvoor. Op basis daarvan wordt een generieke korting toegepast, die kan oplopen tot maximaal $8,3 \%$ voor bedrijven die het minst grondgebonden zijn.

- Mestverdeling - in het mestbeleid van de afgelopen decennia zijn in verband met de negatieve milieueffecten de gebruiksnormen voor dierlijke mest aangescherpt. Hierdoor is in Nederland een mestoverschot ontstaan. Een deel hiervan wordt verwerkt en/of geëxporteerd naar het buitenland. Deze beide oplossingen zijn kostbaar, wat geleid heeft tot een toename van mestafzetkosten voor landbouwbedrijven. Bedragen van meer dan 20 euro per ton afgevoerde mest zijn geen uitzondering meer. Door grond aan te kopen, kan meer mest op het eigen land worden uitgereden en kunnen mestafvoerkosten verlaagd worden. Het plaatsen van bv. 50 ton mest per ha kan daarmee een kostenbesparing van meer dan 1000 euro per ha per jaar opleveren. Berekeningen voor de mestmarkt laten zien dat er bij de huidige veestapel en gebruiksnormen een aanzienlijke opgave ligt voor mestverwerking en export, wat met hoge kosten gepaard gaat. RVO geeft aan dat bij gebruik van landbouwgrond voor zonneparken, deze grond niet meer mag worden meegeteld voor mestplaatsingsruimte (ook niet als eronder beweiding plaatsvindt met bv. schapen).

Tabel 1 Fosfaatgebruiksruimte, mestproductie, bedrijfsoverschot*) en mestverwerkingspercentages 2018**) per regio. Basisvariant, d.w.z. mestacceptatiegraden van $100 \%$ in alle regio's. Bron: CDM (2017).

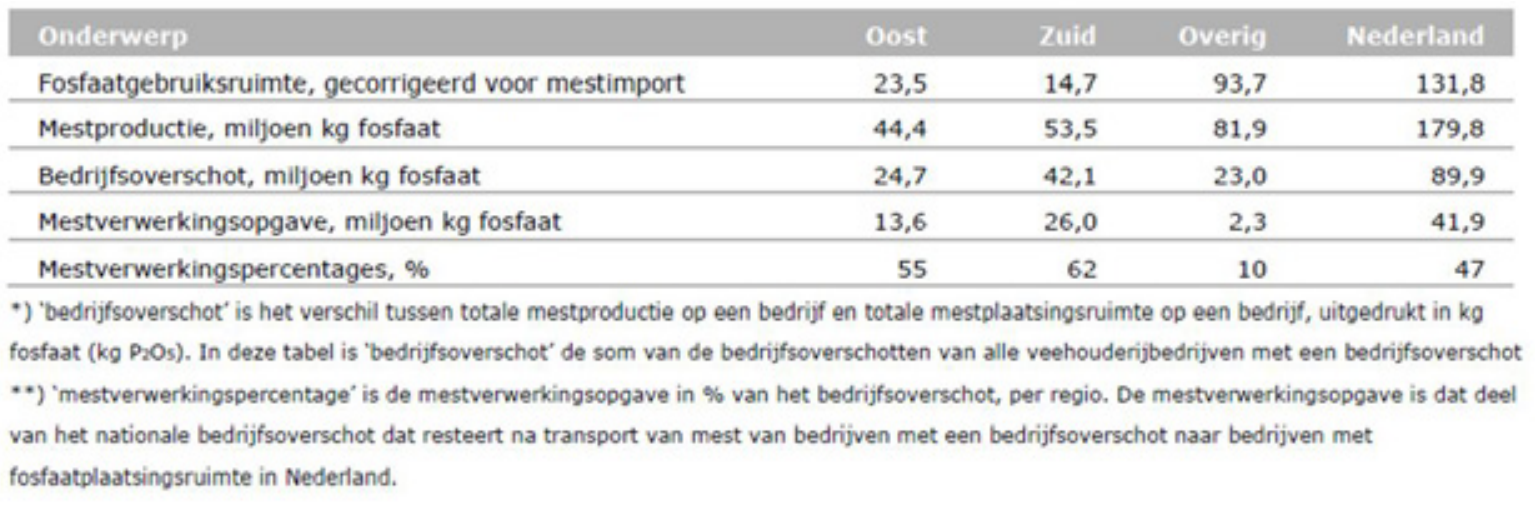

- Kringlooplandbouw - bij de huidige veehouderijsystemen is het meestal zo dat bedrijven minder grond nodig hebben voor voerproductie dan voor afzet van de mest. Dit komt vooral doordat de meeste veehouderijbedrijven veel voer aanvoeren van buiten het bedrijf. In de nieuwe visie van LNV staat het streven naar kringlooplandbouw voorop. Een van de kenmerken daarvan is het sluiten van kringlopen op een zo laag mogelijk niveau. Dit kan door het gebruik van kunstmeststoffen en voeraankopen te verminderen. Daarvoor hebben landbouwbedrijven in principe meer grond nodig. Alternatief is om over te schakelen naar een lagere productie (door minder vee te houden) met een hogere toegevoegde waarde, bv. via een kwaliteitsmerk. Of door voeraankopen te vervangen door aankopen van restproducten, waarbij het nog wel de vraag is in welke mate nog groei mogelijk is in het gebruik van restproducten.

- Natuurinclusieve landbouw - in het algemeen geldt dat in een meer extensief landbouwsysteem meer mogelijkheden zijn voor maatregelen ter bevordering van de biodiversiteit dan in intensieve landbouwsystemen. Om dit te bereiken, hebben landbouwbedrijven in principe meer grond nodig. Alternatief is om over te schakelen naar een lagere productie met hogere prijzen voor hun producten, bv. via een kwaliteitsmerk. Deze ontwikkeling wordt weliswaar voorgestaan in het deltaplan Biodiversiteit, maar het is nog niet duidelijk of dit een niche blijft of mainstream gaat worden. 


\subsection{Effect van zonneparken op de prijs van landbouwgrond}

De ontwikkelingen van paragraaf 4.1 leiden alle tot een extra vraag naar landbouwgrond, die ook duidelijk zichtbaar wordt in de langjarige ontwikkeling van de grondprijs, zie figuur 13. In vijf jaar tijd is de gemiddelde grondprijs gestegen van ongeveer 45.000 naar ca. 60.000 euro per ha. In regio Zuid is de prijs bijna 50\% hoger dan in regio Noord; de regio's Oost en West zitten daartussenin. https://www.agrimatie. $\mathrm{nl} /$ ThemaResultaat. aspx?subpubID =2232\&themaID =3588\&indicatorID = 3589

\section{Prijs van onverpacht land}

Per landsdeel

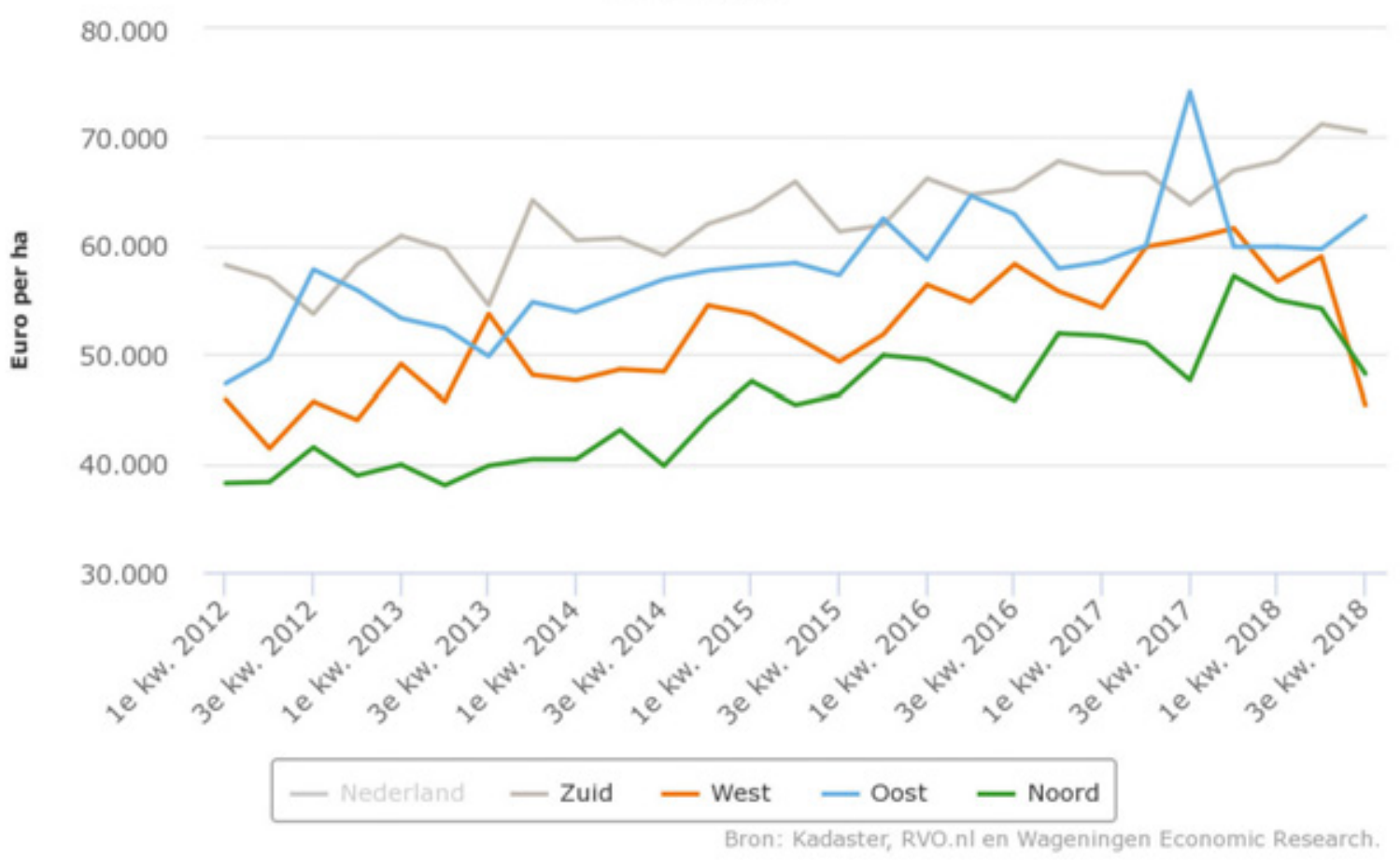

Figuur 13 Grondprijzen per regio in de periode 2012-2018.

In figuur 14 is de hoeveelheid verhandelde grond in de periode 2012-2018 weergegeven. Over de jaren heen is het redelijk stabiel en gaat het om een kleine $2 \%$ van de totale oppervlakte landbouwgrond, ca. 35.000 ha per jaar. Via tijdelijke gebruiksconstructies is er sprak van meer dynamiek tussen bedrijven.

(https://www.agrimatie.nl/ThemaResultaat.aspx?subpubID=2232\&themaID=3588\&indicatorID=3589)

De huidige afname van landbouwgrond van 0,3\% per jaar, betreft dus 0,3 / $2=15 \%$ van de landbouwgrond die op de markt komt, 5000-6000 ha per jaar. Stel dat hierbij $1000^{1}$ ha landbouwgrond voor zonneparken wordt toegevoegd, dan lijkt dat ogenschijnlijk een kleine hoeveelheid. De NVM geeft ook aan dat effect van zonnepanelen op de landelijke grondmarkt naar verwachting beperkt is, maar dat het regionaal, bv. in zoekgebieden die de gemeente aanwijst, sterker kan zijn (https://www.boerderij.nl/Home/Achtergrond/2018/3/Impact-zonnepark-opgrondmarkt-beperkt-260398E/).

Cotteleer et al. (2007, https://edepot.wur.nl/33406) hebben echter laten zien dat de grondmarkt uit segmenten bestaat die in eerste instantie bepaald worden door de bestemmingen, maar in tweede instantie ook door de interactie daartussen. Het ontwikkelde model laat zien dat de prijs van een

\footnotetext{
1 Ter vergelijking: de Nederlandse Vereniging voor Duurzame Energie (NVDE) streeft naar een oppervlakte van 10.000 ha binnen 5 jaar. https://www.boerderij.nl/Home/Achtergrond/2018/3/Impact-zonnepark-op-grondmarkt-beperkt-260398E/
} 
perceel landbouwgrond hoog of laag is door de 'landbouwwaarde' (hoge of lage landbouwdruk), door het speculatie-effect, bij rode gebieden (hoge of lage verstedelijkingsdruk) dan wel door natuurontwikkeling (hoge of lage natuurontwikkelingsdruk). Als het aantal potentiële kopers in een lokale markt daalt van 8 naar 6 , dan neemt de prijs per ha met circa $8 \%$ af (t.o.v. gemiddelde prijs en het gegeven dat er 8 verkopers waren) en andersom. Op een vergelijkbare manier leiden zonneparken tot een extra vraag naar grond, waardoor de grondprijs rond deze locaties waarschijnlijk zal stijgen en verdergaande bedrijfsontwikkeling voor sommige bedrijven moeilijker wordt. Je zou dus analoog aan de andere 'drukken' kunnen spreken van een 'zonneparkendruk'.

Verder zijn mogelijke indirecte effecten een aandachtspunt. Als de landbouwproductie in Nederland daalt door realisatie van zonneparken, zal dat leiden tot minder export van landbouwproducten of tot een grotere import. Dit betekent dat de landbouwproductie in het buitenland zal toenemen, met mogelijk een grotere klimaatbelasting dan voor diezelfde productie in Nederland. Hoe dan ook moet het verlies aan productieareaal gecompenseerd worden, althans bij gelijkblijvende inzet voor diervoederproductie voor de zuivel- en vleesconsumptie.

\section{Agrarische grondmobiliteit naar regio}

\section{Nederland}

15.000

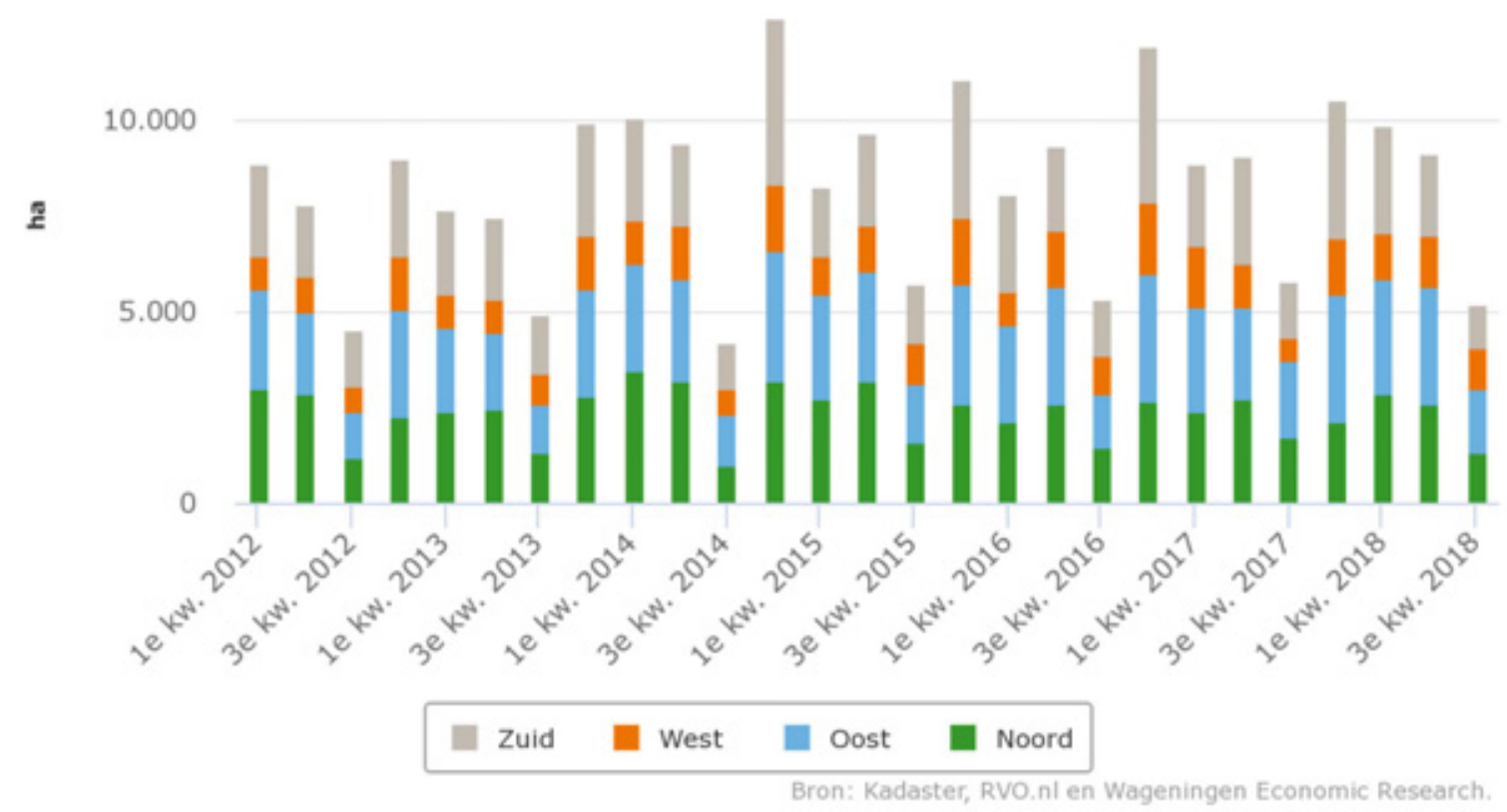

Figuur 14 Agrarische grondmobiliteit in de periode 2012-2018 naar regio.

Samenvattend: we kunnen stellen dat de behoefte aan landbouwgrond door zonnepanelen weliswaar van beperkte omvang is, maar dat lokaal een prijsverhogend effect niet kan worden uitgesloten. Dit kan ertoe bijdragen dat (lokaal) de ontwikkelingsmogelijkheden van blijvende bedrijven worden bemoeilijkt.

\subsection{Zonneparken als tweede tak}

Gevraagd wordt of het opwekken van stroom door middel van zonnevelden als extra pijler voor het agrarisch bedrijf kan dienen. Hiervoor is gekeken naar het financiële plaatje en de benodigde kennis en tijd van de boer. 
Het produceren van elektriciteit door middel van zonnepanelen wordt financieel aantrekkelijk als de opgewekte stroom binnen de eigen elektriciteitsconsumptie valt (salderen) of als sprake is van subsidie (SDE). Zonder subsidie of salderen zal een investering in zonnepanelen op een bedrijfseconomisch aanvaardbare termijn niet rendabel zijn. Hierbij is het uitgangspunt vaak, net als voor de berekening van de SDE-subsidie, dat een investering in 5-15 jaar terugverdiend moet zijn. Voor een SDE+-subsidie moet het piekvermogen Zon-PV hoger zijn dan $15 \mathrm{kWp}^{2}$ (meer dan circa 60 panelen). Dit aantal kan op daken, maar ook in zonneparken bereikt worden.

Deze zonneparken worden met het doel gebouwd om zo veel mogelijk elektriciteit te produceren tegen zo laag mogelijke kosten. De investeringskosten zijn hoog, 650 k euro per ha zonnepark ${ }^{3}$. Spruijt heeft in 2015 de opbrengsten berekend ten opzichte van de teelt van pootaardappelen en wintertarwe (zie tabel 1). Een terugverdientijd van circa 10 tot 15 jaar is berekend op basis van de uitgangspunten in tabel 2 voor de situatie in 2015, waarbij bij een lage SDE+-subsidie of geen subsidie sprake is van een situatie waarbij de kosten niet worden terugverdiend. Hierbij moet worden aangetekend dat deze uitgangspunten sterk verouderd zijn. De rente is nu erg laag en de investering per Wattpiek opgesteld vermogen is sterk gedaald (IEA 2017): het Nationaal Solar Trendrapport uit 2018 rapporteert -40\% tussen september 2016 en september 2017. Het trendrapport van 2019 geeft aan dat de prijsdaling doorging in 2018. Elke verdubbeling van de wereldwijd geproduceerde hoeveelheid panelen leidt tot een prijsdaling van 28,5\% (Nationaal Solar Trend Rapport 2019). Naargelang de situatie kan de terugverdientijd minder lang zijn (bijvoorbeeld belastingvoordeel, schaalvoordelen) of langer (hoge aansluitkosten, funderingsproblemen).

Deze globale kostenberekening is in $\mathbf{2 0 1 5}$ gedaan en is dus relatief oud. Echter geconstateerd is dat in de markt momenteel gerekend wordt met investeringskosten van zo'n 750K euro per hectare. Dit is vergelijkbaar met het rekenvoorbeeld uit 2015. De kosten voor zonnepanelen dalen al jaren achtereen, echter dit is maar een deel van de kosten voor de ontwikkeling van een zonnepark. Globaal worden de volgende kosten ingeschat per hectare zonnepark (uitgaande van park > 10 hectare):

- Panelen 300K euro

- Kabels en aansluiting $100 \mathrm{~K}$ euro

- Constructie $150 \mathrm{~K}$ euro

- Omvormers $150 \mathrm{~K}$ euro

- Planvorming 50K euro

Beter is de kosten uit te drukken in de prijs per geproduceerde MWh zonnestroom. Volgens het nationaal Solar Trendrapport was dit december 2018 \$43,-. De SDE+-subsidie wordt berekend door uit te gaan van een basisbedrag (voorjaar 2018 was dit $€$ 0,112 per kWh) waarvan een marktprijs voor geleverde energie van afgetrokken wordt: voorjaar $2018 € 0,038$. Dit levert een bedrag op van $€ 0,074$ bij levering aan het net. Bij eigen gebruik is de subsidie $€ 0,049$. (bron:

https://www.mijnenergiefabriek.nl/hoe-werkt-zonne-energie/subsidieregeling-sde). Het verschil tussen de wereldmarktkostprijs van $\$ 0.043 \mathrm{kWh}$ met het basisbedrag laat in het algemeen voldoende ruimte voor aantrekkelijke businessmodellen. Wat natuurlijk niet wil zeggen dat zonneparken in alle situaties rendabel zijn. De kostprijs van stroom uit kleinschalige zonnestroominstallaties op daken is veel hoger: $€ 0.088-€ 0.319$ per kWh.

Voor de rentabiliteit is verder nog van belang dat een zonnestroominstallatie niet echt na 15 jaar is afgeschreven. Algemeen wordt aangenomen dat deze ten minste 25 jaar meegaat en misschien wel 40 jaar. Na het terugverdienen van de installaties blijft deze nog lang tegen lage kosten stroom produceren.

Een alternatief is het verpachten van de grond aan grootschalige ontwikkelaars van zonneparken. Pachtprijzen van 4.000 tot 8.000 euro per hectare per jaar voor de duur van 20 jaar worden genoemd, onder andere door De Stentor ${ }^{4}$. Deze pachtprijzen concurreren met de huidige gewasopbrengsten per hectare en de inspanning voor de boer is hierbij minimaal. Wel moet hierbij de kanttekening geplaatst worden dat de geproduceerde duurzame stroom niet wordt toegerekend aan

\footnotetext{
2 RVO 10-januari 2019 https://www.rvo.nl/subsidies-regelingen/stimulering-duurzameenergieproductie/categorie\%C3\%ABn/zon-sde

3 Spruijt J., maart 2015, Wat levert een zonneweide per hectare op?, PPO 642

4 De Stentor, 25 november 2018, Oost-Nederland werkt aan 50 nieuwe zonneparken: Invasie van de 'energiecowboys', https://www.destentor.nl/raalte/oost-nederland-werkt-aan-50-nieuwe-zonneparken-invasie-van-deenergiecowboys ab3ca9c3/
} 
het boerenbedrijf, tenzij hierover afspraken worden gemaakt tussen de zonnepark-ontwikkelaar en de betreffende boer.

Tabel 2 Berekende opbrengsten per hectare (Bron: Spruijt 2015).

\begin{tabular}{|c|c|c|c|c|c|c|c|}
\hline & \multicolumn{2}{|c|}{$\begin{array}{c}\text { Opbrengst } \\
\text { per ha }\end{array}$} & \multicolumn{2}{|c|}{ Prijs } & \multirow{2}{*}{$\begin{array}{c}\text { Bruto } \\
\text { geldopbrengst } \\
\text { per ha }\end{array}$} & \multirow{2}{*}{$\begin{array}{l}\text { Toegerekende } \\
\text { kosten } \\
\text { per ha }\end{array}$} & \multirow{2}{*}{$\begin{array}{c}\begin{array}{c}\text { Saldo } \\
\text { per ha }\end{array} \\
€ 1.147\end{array}$} \\
\hline wintertarwe $^{1}$ & 9.200 & $\mathrm{~kg}$ & 0,16 & $€ / \mathrm{kg}$ & & & \\
\hline pootaardappelen $^{3}$ & 40.000 & $\mathrm{~kg}$ & 0,30 & $€ / \mathrm{kg}$ & $€ 12.000$ & $€ 3.300$ & $€ 8.700$ \\
\hline \multicolumn{8}{|l|}{ zonnestroom } \\
\hline zonder SDE & 500.000 & kWh & 0,045 & $€ / k W h$ & $€ 22.500$ & $€ 1.000$ & $€ 21.500$ \\
\hline SDE Fase 1 & 500.000 & kWh & 0,07 & $€ / \mathrm{kWh}$ & $€ 35.000$ & $€ 1.000$ & $€ 34.000$ \\
\hline SDE Fase 2 & 500.000 & kWh & 0,08 & $€ / k W h$ & $€ 40.000$ & $€ 1.000$ & $€ 39.000$ \\
\hline SDE Fase 3 & 500.000 & kWh & 0,09 & $€ / k W h$ & $€ 45.000$ & $€ 1.000$ & $€ 44.000$ \\
\hline SDE Fase 4 & 500.000 & kWh & 0,10 & $€ / k W h$ & $€ 50.000$ & $€ 1.000$ & $€ 49.000$ \\
\hline SDE Fase 5 & 500.000 & kWh & 0,11 & $€ / k W h$ & $€ 55.000$ & $€ 1.000$ & $€ 54.000$ \\
\hline SDE Fase 6 & 500.000 & kWh & 0,12 & $€ / k W h$ & $€ 60.000$ & $€ 1.000$ & $€ 59.000$ \\
\hline SDE Fase 7 & 500.000 & kWh & 0,13 & $€ /$ kWh & $€ 65.000$ & $€ 1.000$ & $€ 64.000$ \\
\hline SDE Fase 8 & 500.000 & kWh & 0,14 & $€ / k W h$ & $€ 70.000$ & $€ 1.000$ & $€ 69.000$ \\
\hline SDE Fase 9 & 500.000 & kWh & 0,141 & $€ / k W h$ & $€ 70.500$ & $€ 1.000$ & $€ 69.500$ \\
\hline
\end{tabular}

In bovenstaande tabel is geïllustreerd dat de SDE-subsidies in fasen beschikbaar worden gesteld. Het subsidiebedrag stijgt per fase, maar het risico van langer wachten is dat het jaarlijkse maximum bereikt is. Een systeem vergelijkbaar met tuinbouwveilingen.

Tabel $3 \quad$ Uitgangspunten voor berekening terugverdientijd (Bron: Spruijt 2015).

\begin{tabular}{|l|l|}
\hline stroomopbrengst & $500 \mathrm{MWh} / \mathrm{ha}$ \\
\hline $\begin{array}{l}\text { investering } \\
\text { eigen investering }\end{array}$ & $€ 650,000$ \\
\hline rente & $100 \%$ of $20 \%$ \\
\hline rentekorting jr 1-5 & $5.5 \%$ \\
\hline rentekorting jr 6-10 & $1.1 \%$ \\
\hline aflossingstermijn & $0.8 \%$ \\
\hline afschrijvingstermijn & 10 jaar \\
\hline grondkosten & 15 jaar \\
\hline overige jaarlijkse kosten & $€ 1.000$ per ha per jaar \\
\hline
\end{tabular}

Anders dan bij vergistingsinstallaties waar een hoge mate van kennis van de boer verwacht wordt, is bij zonneparken de belasting minimaal en kan de exploitatie in eigen beheer worden uitgevoerd, maar ook door externe partijen. De investeringskosten zijn relatief hoog en kunnen voor een deel door vreemd vermogen ingevuld worden; hierdoor wordt wel de terugverdientijd vergroot.

In opdracht van $\mathrm{RVO}^{5}$ is het verbruik op melkveebedrijven gemeten. Het elektriciteitsverbruik is opgedeeld in hoog, gemiddeld en laag verbruik, respectievelijk 88, 57 en 21 kWh per 1.000 kg melk. Voor een bedrijf met een melkopbrengst van $1.000 .000 \mathrm{~kg}$ melk (circa gemiddelde grootte) betekent dit een jaarverbruik van 88.000, 57.000 en $21.000 \mathrm{kWh}$.

Om elektrisch gezien energieneutraal te worden, zullen bij een hoog verbruik circa 400 panelen en bij een laag verbruik circa 100 panelen nodig zijn om de elektrische energiebehoefte te neutraliseren (uitgaande van panelen van 250 wattpiek met een opbrengst van $215 \mathrm{kWh}$ per jaar). Uitgaande van $2 \mathrm{~m}^{2}$ benodigd dakoppervlak per paneel is circa 800 tot $200 \mathrm{~m}^{2}$ geschikt dakoppervlak nodig. Verwacht wordt dat de meeste boerenbedrijven genoeg elektriciteitsopwekking door middel van zonnepanelen kwijt kunnen op hun dakoppervlak, eventueel aangevuld met zonnepanelen op het erf. De trend is dat

\footnotetext{
5 Ruitenberg G., R. Jacobs, Juli 2014, Verkenningen mogelijkheden voor het verlagen van het energieverbruik in de melkveehouderij, RVO
} 
het Wattpiekvermogen van de panelen bij gelijke oppervlakte nog verder zal toenemen. Tegenwoordig zijn vermogens van $300 \mathrm{Wp}$ normaal en de eerste panelen van meer dan $400 \mathrm{Wp}$ zijn al op de markt.

Indien voor volledig energieneutraal gekozen wordt, zullen diesel en gasverbruik ook meegenomen moeten worden. Er zal dan grofweg 75\% meer opwekcapaciteit nodig zijn. Voor akkerbouwbedrijven ligt het elektriciteitsverbruik veel lager, maar de energiebehoefte is groter als dieselgebruik voor het landwerk ook wordt meegeteld.

Een belangrijke factor voor het ontwikkelen van zonneparken zijn de ligging en capaciteit van het elektriciteitsnetwerk. Het maken van een aansluiting voor een zonnepark kan onevenredig hoge kosten met zich meebrengen, de zoektocht naar de geschiktste locatie en vorm voor elektriciteitsopwekking met zonnepanelen zal zeer sterk door deze variabele beïnvloed worden.

\section{Samenvattend}

Indien een landbouwer voldoende middelen heeft, dan is het investeren in zonnepanelen op daken of erf of een zonnepark op percelen een goede mogelijkheid om een zekere cashflow te genereren. Als de energiebehoefte op landbouwbedrijven sterk toeneemt door meer automatisering en door omschakelen van dieselgebruik naar elektriciteit, leveren de zonnepanelen op daken niet meer voldoende elektriciteit voor de eigen energiebehoefte en zal het nodig zijn dat ook het erf of de perceelranden benut worden voor de aanleg van zonnepanelen. Vooral het verpachten van grond aan zonnepark-ontwikkelaars zal voor de meeste landbouwers financieel gezien voordelig zijn. Dit zal wel impact hebben op de bedrijfsvoering, maar de huidige pachtprijzen die betaald worden door de energieleverancier overstijgen de landbouwkundige winst die ervan het land gehaald kan worden.

\subsection{Landbouwproductie onder zonnepanelen}

De doelstelling van de huidige zonneparken is een zo hoog mogelijke elektriciteitsproductie te halen per hectare, agrarische productie wordt niet meegenomen in het ontwerp. De huidige zonneparken met een hoge concentratie van panelen op een perceel bieden dan ook weinig mogelijkheden tot agrarische productie. Voor akkerbouw zijn de huidige vormen van zonneparken niet geschikt, combinaties van zonnepark en veeteelt zijn in de huidige vorm van zonneparken wel mogelijk, bijvoorbeeld: uitloop van biologische kippen met zonnepanelen (bij vrije uitloopkippen is dit nog verboden $)^{6}$ of schapen onder zonneparken (vooral als beheersmaatregel voor het gras).

Elektriciteitsopwekking met zonnepanelen en agrarische productie zijn goed te combineren, mits beide functies worden meegenomen in het ontwerp. Door een dubbel doel na te streven, zal in Nederland genoegen moeten worden genomen met een lagere elektriciteitsopwekking en een lagere gewasopbrengst per ha. Door de zonnepanelen te verspreiden over meerdere ha's in plaats van te concentreren op enkele ha's, zal de economie van energieproductie en landbouw echter over de totale ha's landbouw en zonneparken beoordeeld moeten worden in plaats van per ha zonnepark. Momenteel zijn er innovaties die een gecombineerd landgebruik mogelijk maken. Op hoofdlijnen zijn er drie denkrichtingen:

- Configuratie/plaatsing zonnepanelen

- Mobiele panelen

- Lichtdoorlatende zonnepanelen

RVO heeft in $2015^{7}$ een studie laten uitvoeren naar mogelijke inpassing van zonneparken in het landelijk gebied. Daarin wordt al vastgesteld dat een goed afwegingskader nodig is.

\footnotetext{
6 De Boerderij, 27 november 2018, zonnepanelen niet toegestaan in kippenuitloop

7 ROM3D, 2015, Grondgebonden Zonneparken, https://www.rvo.nl/sites/default/files/2016/09/Grondgebonden\%20Zonneparken\%20-

\%20verkenning\%20afwegingskadersmetbijlagen.pdf
} 


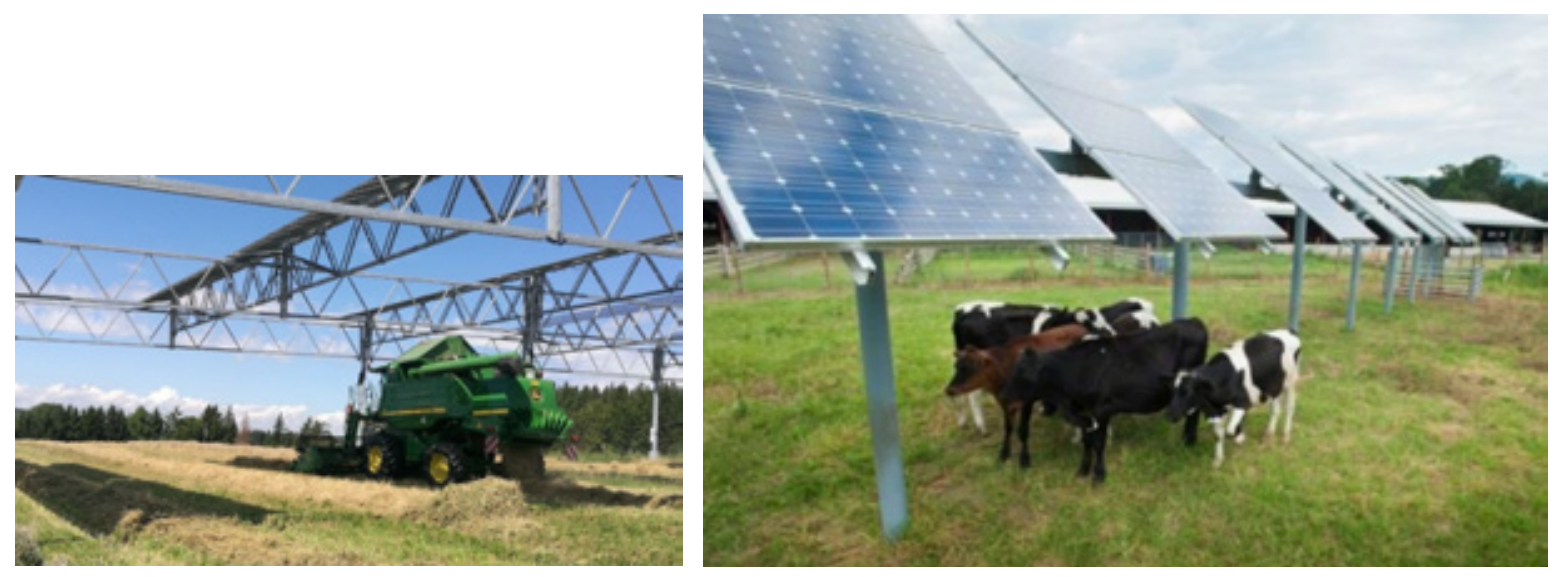

Figuur 15 Links akkerbouw onder zonnepanelen op hoogte (bron: de Ingenieur). Rechts veeteelt onder zonnepanelen (bron: RVO 2015).

Om voldoende licht en water toe te laten voor plantengroei kan ervoor gekozen worden om een zonnepark aan te leggen met een lage dichtheid aan panelen. Een simpele manier is het zodanig plaatsen van de panelen dat zonlicht bij de gewassen kan komen en dat er ruimte is om het land te bewerken. Dit kan door stroken met zonnepanelen af te wisselen met stroken voor gewassen. Of bijvoorbeeld het plaatsen van zonnepanelen als afdak voor vee. Ook mogelijk is het initiatief van het Fauenhofer Institut $^{8}$, waarbij zonnecellen op een hoogte van $>5 \mathrm{~m}$ worden geplaatst met een lage dichtheid (panelen per ha). Zowel opbrengsten in elektriciteit als in gewas zijn minder per ha ten opzichte van geconcentreerde, niet-geïntegreerde zonneparken (enkel doel), echter tezamen (wel geïntegreerd (dubbeldoel)) zijn de absolute opbrengsten van de totale ha's hoger, althans in mediterrane landen (Dupraz et al., 2011; Valle et al., 2017; Majumdar \& Pasqualetti, 2018). Onduidelijk is of deze integratie van landbouw en elektriciteitsopwekking in Nederland kan leiden tot financiële voordelen.

Ook kan gedacht worden aan het plaatsen van panelen langs de randen van percelen. Het plaatsen van rechtopstaande panelen die bifacial zijn kan hierin een rol spelen. De bifacial panelen zijn duurder, maar hebben als bijkomend voordeel dat de elektriciteitsproductie beter verspreid over de dag is. Dit voordeel wordt belangrijker indien er in de toekomst een prijsverschil zou komen tussen elektriciteit opgewekt in de zomermaanden ten opzichte van andere maanden of 's ochtends en 's avonds ten opzichte van midden op de dag.

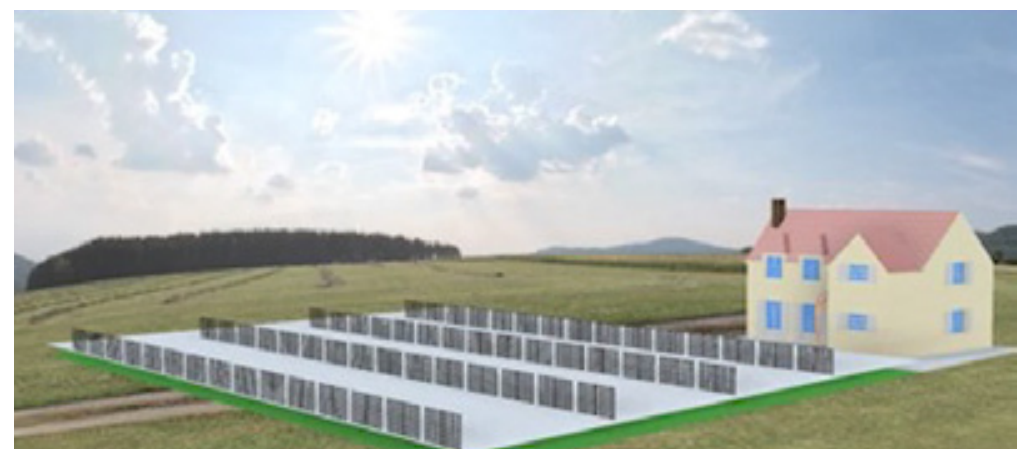

Figuur 16 Mogelijkheden bifacial verticale zonnepanelen, Bron: RVO-prijsvraag zonnestroom, https://www. youtube.com/watch?v=DQdzRsC3qTU.

\footnotetext{
8 De ingenieur, 28 november 2017, Akkerbouw onder zonnepark
} 
Met de tabel van Hespul (zie figuur 17) kan bepaald worden welke opbrengstverliezen er optreden bij afwijkende plaatsing van de zonnepanelen. Momenteel worden de meeste zonneparken op het zuiden gericht. Bij bijvoorbeeld een zuid-opstelling en een hellingshoek van de zonnepanelen tussen 10 en 55 graden wordt de maximale energieproductie (95-100\%) bereikt. Bij een oost-west-opstelling heb je twee keer zoveel panelen nodig die samen bij een lage hellingshoek tot ca. 25 graden een energieopbrengst opleveren van totaal ca. $176 \%$ (= 2x $88 \%)$.

Verticale panelen in zuid-opstelling hebben een opbrengst van ca. $71 \%$ t.o.v. het maximaal mogelijke. En verticale oost-west (Bifacial) is $56+58=114 \%$.

$\mathrm{Bij}$ een oost-west-opstelling heb je een betere verdeling van de energieproductie, dit levert financieel voordeel op indien er een prijsverschil zou komen tussen piek- en daluren.

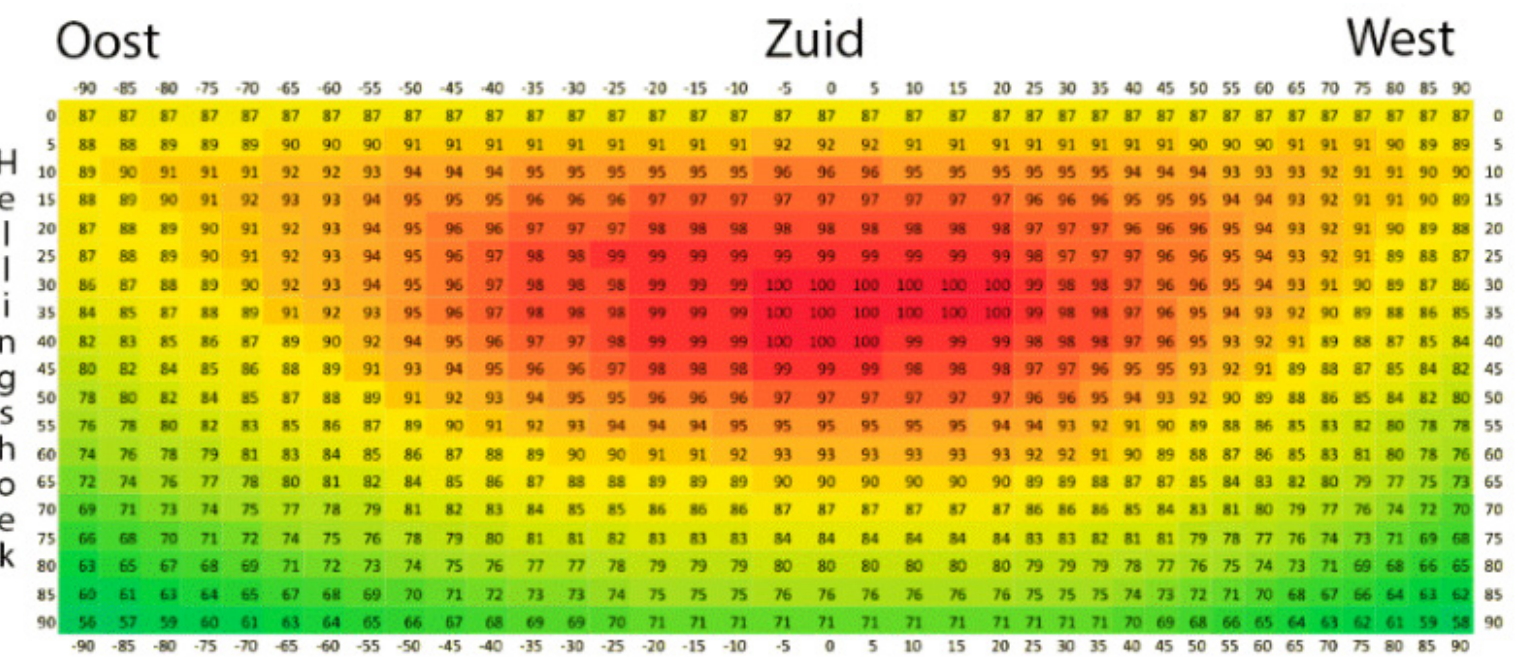

Figuur 17 Tabel van Hespul, op basis van de hellingshoek en de richting kan bepaald worden hoe groot de opbrengst is ten opzichte van de ideaalste opstelling (rood 100\%, oranje 90-100\%, geel 80 $90 \%$, groen $60-70 \%)$.

De tabel van Hespul is van toepassing indien geen gebruikgemaakt wordt van 'solar tracking'. Er zijn diverse opstelsystemen op de markt die de panelen, op elke tijdstip van de dag, in één of twee dimensies richten op de zon. Je combineert daarmee de voordelen van verschillende oriëntaties. De kosten van deze systemen zijn vrij hoog. In Nederland worden ze zelden toegepast.

Mobiele panelen

Door de panelen mobiel te maken, kunnen deze meebewegen met de ritmes van het bedrijf. Bijvoorbeeld bij het verweiden van de koeien of het braak liggen van akkerland. Door de zonnepanelen langzaam te verplaatsen, wordt de schaduw evenredig verdeeld over het veld. Er zijn initiatieven, maar deze systemen dienen nog verder ontwikkeld te worden. 


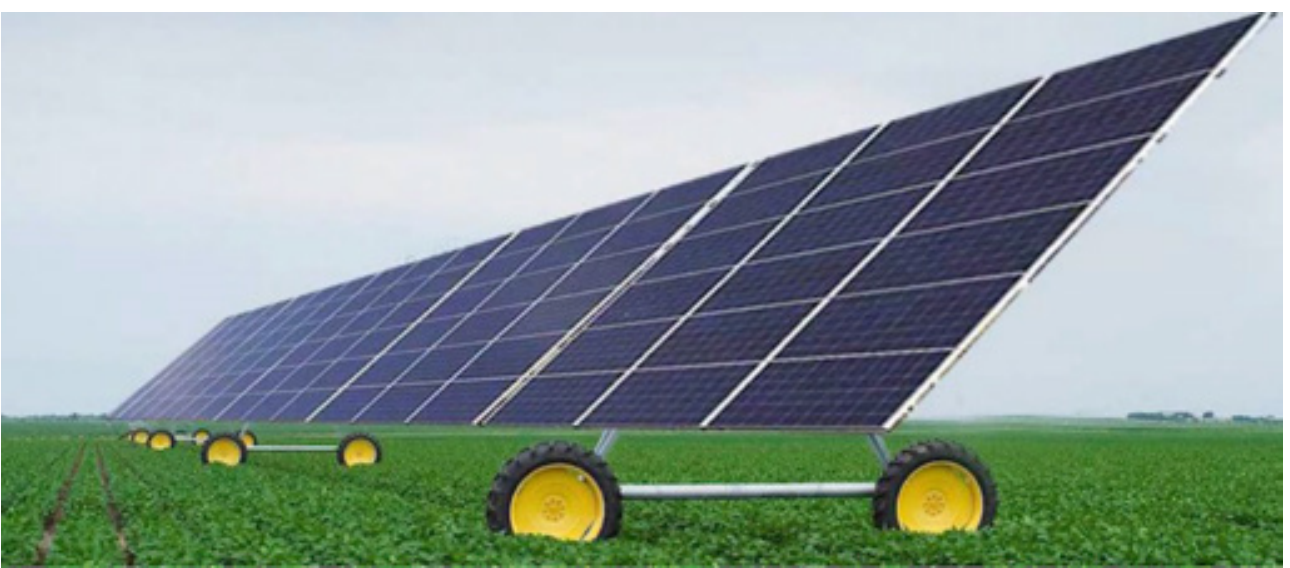

Figuur 18 Zonnepanelen op rijdende constructie. Bron: RVO-prijsvraag zonnestroom, https://www.youtube.com/watch?v=DQdzRsC3qTU.

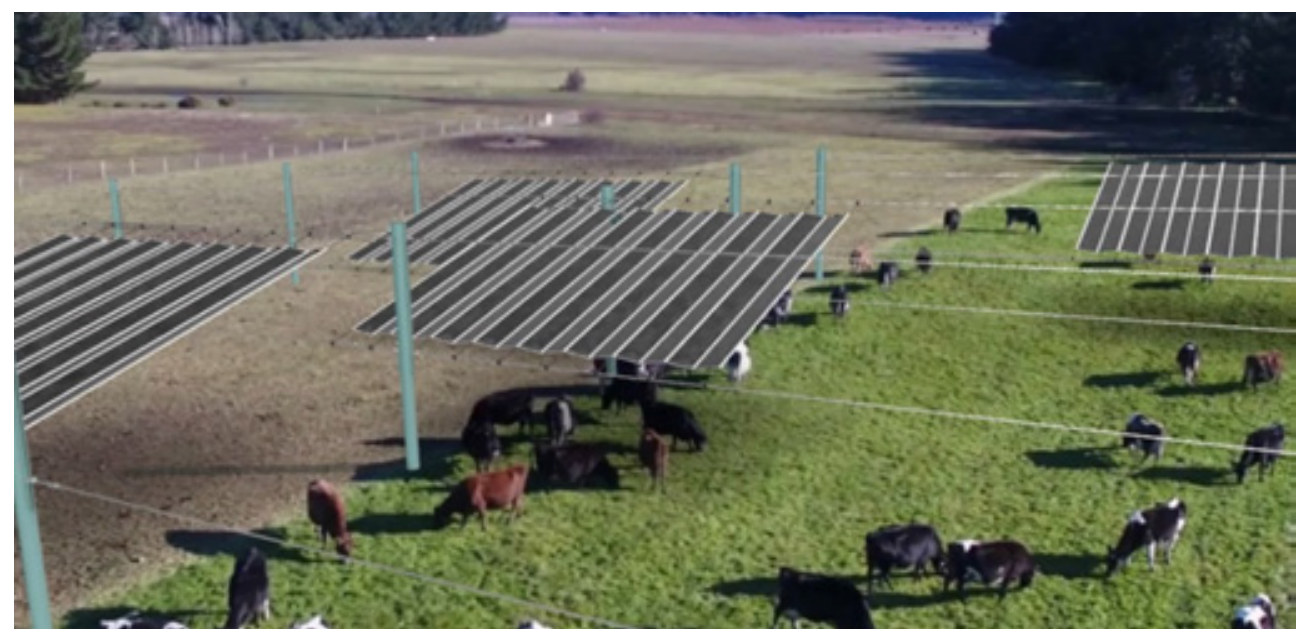

Figuur 19 Zonnepanelen beweegbaar en opvouwbaar. Bron: RVO-prijsvraag zonnestroom, https://www. youtube.com/watch?v=DQdzRsC3qTU.

\section{Lichtdoorlatende zonnepanelen}

Lichtdoorlatende zonnepanelen zorgen ervoor dat het gewas eronder blijft groeien. De uitdaging is om zonnepanelen te ontwikkelen die de golflengten voor bladgroen doorlaten en de overige straling omzet in elektriciteit. Hier wordt onderzoek naar gedaan. Toepassing op bijvoorbeeld kassen wordt dan ook mogelijk.

\section{Opbrengsten gewassen onder zonnepanelen}

Voor plantengroei is licht een belangrijke factor. De zonnepanelen op landbouwgrond houden een gedeelte van het licht tegen. Het spectrum dat door planten wordt gebruikt voor de fotosynthese wordt ook door de zonnepanelen gebruikt voor elektriciteitsopwekking. Over verliezen qua gewasopbrengsten onder zonneparken is weinig bekend. Alleen de eerder aangehaalde studies uit Zuid-Frankrijk en Italië zijn beschikbaar.

In het kader van een mastervak heeft een team studenten van de Wageningen Universiteit modelmatig berekend dat een schaduwoppervlak van circa 70\% resulteert in een gewasverlies van circa $50 \%$. Er is dus een indicatie dat het effect van de zonnepanelen minder ernstig is dan wat op basis van oppervlakte schaduw te verwachten zou zijn.

Aroca-Delgado (2018) heeft een review uitgevoerd naar het gebruik van zonnecellen in combinatie met kasteelten. Conclusie is dat dit wereldwijd in de belangstelling staat. Het idee erachter is dat door middel van (beperkte) schaduwvorming of beperkt doorlaten van licht schade aan gewassen door een overschot aan licht kan worden vermeden. In zuidelijke streken speelt ook een reductie van de 
verdamping van schaars water een grote rol. Deze zonnepanelen krijgen dan dezelfde functie als doeken of bekalking van het dak. Voor de Nederlandse open teelten is dit minder van belang. Het Frauenhofer instituut heeft een grafiek gemaakt met de gewasopbrengsten en de instraling (zie figuur 20). Hieruit blijkt dat onder de omstandigheden die zij bekeken hebben, sommige gewassen baat hebben bij verminderde instraling. Er is niet genoemd hoe deze grafiek verkregen is en de waarde ervan is dus niet te bepalen. Daarom kunnen we geen uitspraak doen over de Nederlandse situatie. Wel wordt verwacht dat bepaalde gewassen (in het geval van figuur 19 aardappelen) of specifieke schaduwgewassen baat kunnen hebben bij een vermindering van de instraling, terwijl andere gewassen, bijvoorbeeld graan, in dit geval direct een verlaging van de opbrengst laten zien.

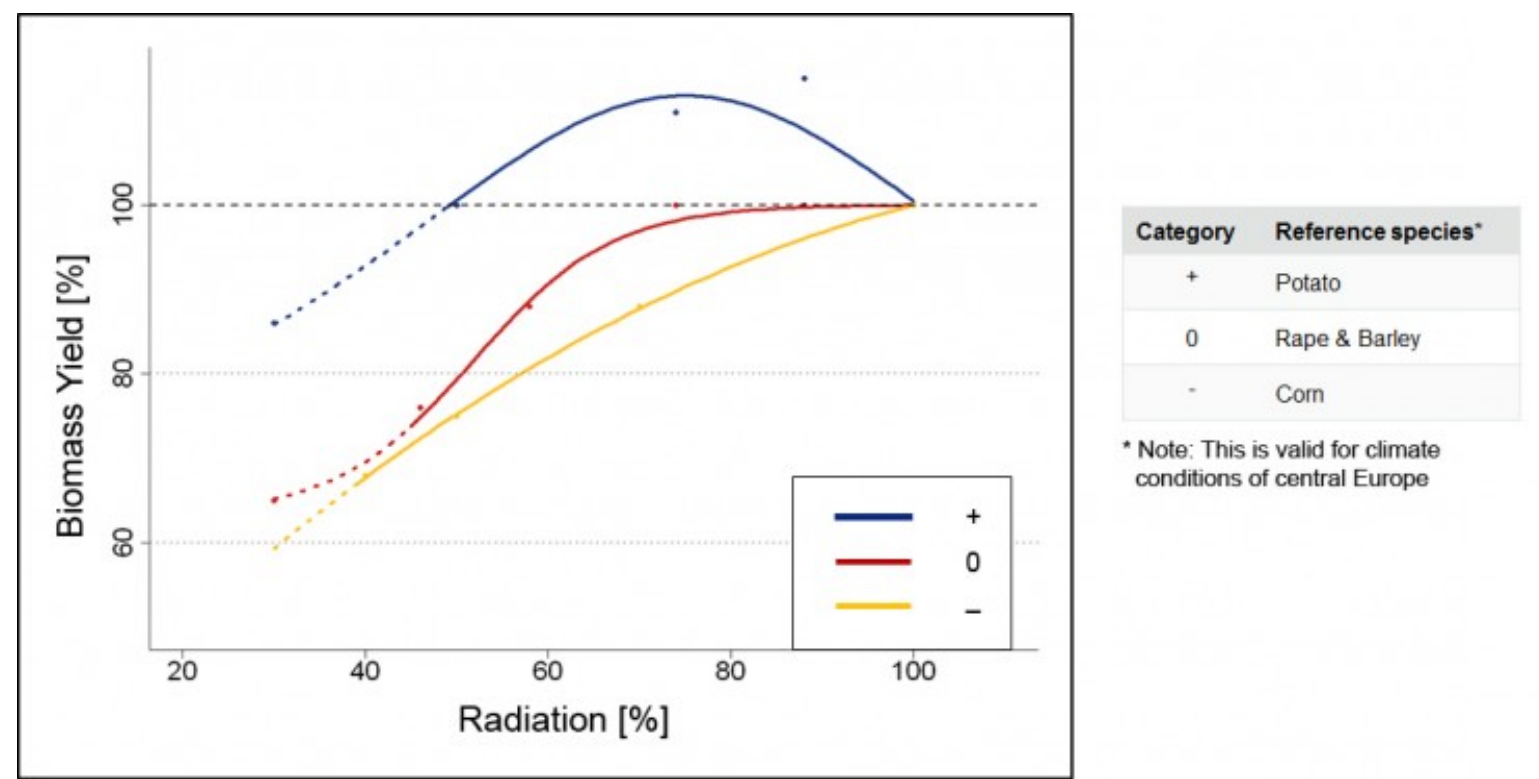

Figuur 20 Bruikbare gewassen - casestudy Germany, bron Blog Tabea Obergfell (Frauenhofer), Agrophotovoltaics - Existing Solution for New Problems. September 2016.

\subsection{Gevolgen zonneparken op bodemvruchtbaarheid landbouwgrond}

Langdurige overdekking van de bodem onder zonnepanelen leidt naar verwachting tot afname van bodemvruchtbaarheid. Hoe veel en hoe snel weten we niet. De voornaamste zorg is dat minder licht en een andere verdeling van het water via minder planten(wortels) zullen leiden tot minder bodemleven en lagere organische stofgehalten (hoofdstuk 2). Dit is met name van belang als de grond later, na bijvoorbeeld 25 jaar, door een volgende generatie weer voor landbouw gebruikt zou worden. Uit langetermijnbemestingsproeven weten we dat opbouw van het organische stofgehalte in de bodem langzaam gaat en vaak pas na meer dan 10 jaar meetbaar wordt. Veranderingen in bodemleven zijn sneller zichtbaar. Door de vele kleine poriën in kleigrond worden organische stof en micro-organismen beter beschermd tegen afbraak dan in lichtere gronden. Daarom breekt organische stof sneller af in zandgrond. Omgekeerd duurt herstel van organische stof en bodemleven waarschijnlijk ook langer op lichte gronden. Op een intensief bewerkte akker op lichte zavel was pas na 18 jaar een duidelijke toename van organische stof in de bodem meetbaar na langdurige toediening van (slechts) bepaalde organische mestsoorten. De best werkende mestsoorten, zoals vaste stalmest, zijn tegenwoordig niet meer ruim voorhanden en de giften worden beperkt door mestwetgeving (Bloem et al., 2017). Het algemene beeld uit langetermijnproeven is dat na 20 jaar organische bemesting het organische stofgehalte $20-30 \%$ hoger is dan bij toepassing van alleen kunstmest. Het hogere organischestofgehalte gaat gepaard met meer bodemleven, meer mineralisatie (nutriëntenlevering) en een betere benutting van stikstof uit organische stof. Er zijn aanwijzingen dat op kleigrond meer verbetering kan worden bereikt dan op zandgrond ( $25 \%$ versus $10 \%$ ). Het is duidelijk dat als 
zonneparken inderdaad zouden leiden tot afname van de bodemvruchtbaarheid, het herstel van goede landbouwgrond een generatie kan duren.

\subsection{Combinatiemogelijkheden zonnepanelen en landbouw}

De gevolgen van aanleg van zonnepanelen voor de landbouw en het rendement van de energieproductie hangen af van de mate van integratie, namelijk:

1. Beperkte integratie door toepassing op daken of erf.

2. Integratie op grotere schaal in een zonnepark, op hoofdlijnen zijn er drie mogelijkheden:

a. uitgaande van minimale belasting landbouw;

b. uitgaande van maximale energieproductie per ha;

c. uitgaande van optimaliseren combinatie landbouw en energieproductie in groter gebied.

Opgemerkt moet worden wanneer landbouwgrond volledig en langjarig wordt verhuurd voor een zonnepark dit gevolgen kan hebben voor diverse regelingen. Dit geldt vooral voor optie $2 b$, en is onduidelijk voor optie 2c. De VLB (Vereniging van Accountants- en Belastingadviesbureaus) waarschuwt dat verlies van bestemming landbouwgrond deze grond niet meetelt voor de wet grondgebonden groei melkveehouderij en de plaatsingsruimte voor mest wordt beperkt. Ook telt deze grond binnen het GLB niet meer mee en wordt daardoor uitgesloten van de betalingsrechten. Ook wordt geattendeerd op fiscale gevolgen.

\section{Ad 1. Beperkte integratie door toepassing op daken en erf}

Deze toepassing kan gezien worden als verhuur van daken en erf aan derden die gebruikmaken van de energie opgewekt door de zonnepanelen en/of zelf investeren voor eigen energievoorziening. Het aantal benodigde zonnepanelen op een landbouwbedrijf voor eigen energievoorziening hangt af van de energiebehoefte. Dit verschilt per landbouwsector. De elektriciteitsbehoefte op een melkveebedrijf als voorbeeld kan de komende jaren toenemen door toenemend gebruik van automatisering voor het melken, het voeren en reinigen van vloeren. Ook kan gedacht worden aan landwerk indien tractoren op diesel vervangen zouden worden door elektriciteit, mits praktisch inpasbaar (met name telkens opladen kan beperkend zijn). Bij een toenemende energiebehoefte zal naast het dak op veestallen ook een deel van het erf nodig zijn voor het plaatsen van zonnepanelen, bijvoorbeeld:

- als overdekking van een uitloop (kippen, varkens, melkvee, jongvee).

Het opvangen van mest en urine in die uitloop vergt aandacht van de veehouder en vergt aanvullend beleid. Onduidelijk is of een overdekte uitloop voor bijvoorbeeld melkvee of jongvee gezien wordt als stal of niet. Zo ja, dan zal het ook aan de milieueisen van een stal moeten voldoen, zoals het verkrijgen van een RAV-code (ammoniakemissie factor) voor een overkapte uitloop.

Bij pluimvee zijn er mogelijkheden zonnepanelen te combineren met een uitloop. De eisen die gesteld worden aan de uitloop verschillen tussen biologische en beter leven-keurmerken (1, 2 of 3 sterren). Belangrijk is te letten op voldoende licht voor de dieren, voldoende oppervlakte en voorzieningen voor water en voer.

Voor alle diersoorten geldt dat extra eisen aan de constructie nodig zijn om beschadiging door de dieren te voorkomen.

- op het erf:

- langs (bij voorkeur) of op sleufsilo's (vereist opvouwbare panelen om hoogte te beperken);

- langs erfranden, mits geen schaduw van beplanting;

- rijpaden op erf (en eventueel in het land), mits voldoende hoogte voor machines en vrachtwagens.

Dit stelt hoge eisen aan de constructie.

Ad 2a. Integratie op grotere schaal in een zonnepark; met minimale belasting landbouw Door de zonnepanelen te plaatsen langs perceelranden, op of langs sloten, wordt de landbouw minimaal belast. Ook is er de mogelijkheid zonnepanelen te plaatsen in bermen, maar dit valt buiten de landbouw. Of gedacht kan worden aan de combinatie met windmolens. Zonneparken en windmolens kunnen een aansluiting op het net delen, met grote kostenbesparingen tot gevolg. 
Ad $2 b$. Integratie op grotere schaal in een zonnepark; met maximale energieproductie per ha Door de zonnepanelen te concentreren op enkele ha's maximaliseer je de elektriciteitsproductie per ha, maar zijn er slechts beperkt mogelijkheden deze te combineren met landbouw. Schapen (als grasmaaier) zouden kunnen dienen als beheersmaatregel. Voor kleine dieren als pluimvee en eventueel varkens is er in principe de mogelijkheid deze te gebruiken als uitloop, echter dit vergt wel voldoende ruimte tussen de panelen om ook aan de eis van open ruimte te voldoen. En een uitloop stelt eisen aan milieu en extra bescherming van een stevige constructie om beschadiging van de dieren te voorkomen.

Ad 2c. Integratie op grotere schaal in een zonnepark; optimaal combineren landbouw en energie Door de functies te combineren, zal een vergunning nodig zijn om de zonnepanelen te verspreiden over een groter gebied. Het gaat dan niet om de opbrengst per ha zonnepark, maar om het verdienmodel van het totaalaantal ha's landbouw en zonnepanelen. De combinatie kan meer opbrengst genereren, maar vergt ook extra kosten. De extra kosten door panelen te spreiden, zijn onvoldoende bekend; denk aan kosten voor:

- extra bekabeling;

- mobiel maken panelen: o.a. kosten voor verankeren tegen stormschade;

- type paneel: verticale panelen hebben de voorkeur, echter zijn duurder en gevoeliger voor storm;

- lichtdoorlatende panelen: zijn duurder om dezelfde energie hoeveelheid te leveren;

- minder ha's voor mestaanwending: voor intensieve bedrijven betekent dit extra mestafzet;

- onduidelijk is hoeveel ha's vervallen bij een combinatie zoals hier geschetst;

- landwerkzaamheden; panelen in land met bijbehorende constructie belemmeren landwerkzaamheden.

De combinatie met gewassen kan op verschillende manieren:

- strook panelen combineren met strokenteelt van gewassen: vaste opstelling of mobiel;

- vaste constructie in het land waar machines onderdoor kunnen waardoor gewasproductie onder panelen mogelijk is met beperkte daling van de gewasopbrengsten, afhankelijk van type gewas.

Het effect van zonnepanelen op de gewasopbrengst en -kwaliteit verschilt per gewas en hangt af van type paneel, vast of mobiel en van de hoogte. Door slimme ontwerpen kan mogelijk een microklimaat onder de panelen gecreëerd worden die de schade aan gewassen beperkt of misschien de productie zelfs positief beïnvloedt. Andersom kan de teelt, bijvoorbeeld onder folie, zorgen voor extra energieopbrengst door weerkaatsing van licht, met name bij gebruik van bifacial panelen (dubbelzijdig).

\subsection{Conclusies en kennisleemten}

- Het blijkt dat een zonnepark financieel duidelijk meer oplevert dan grondgebonden veehouderij of akkerbouw. Voor stoppende boeren en akkerbouwers kan het een verleidelijk alternatief zijn, waarmee echter de ontwikkelingsruimte voor blijvende bedrijven wordt beperkt. Voor melkveehouders zal de grondgebondenheid een belangrijke factor zijn, waardoor niet snel gekozen wordt voor zonneparken. In het streven naar een duurzamere landbouw (natuurinclusief, circulaire landbouw, mestnormen) hebben boerenbedrijven juist behoefte aan meer grond; de grondprijzen laten dan ook een stijgende lijn zien. Of de aanleg van een zonnepark financieel aantrekkelijk is, hangt ook in sterke mate af van de kosten voor aansluiting op het net. Hoe groter de afstand tot het openbare net, hoe hoger de kosten.

- Er lijkt een groot scala aan combinaties van landbouw en zonneparken mogelijk door panelen op hoogte te installeren, op en rond erven of langs perceelranden. De combinatie met een uitloop van dieren (jongvee, melkvee, varkens of pluimvee) vergt aanvullend beleid (milieu en dierenwelzijn) dat eisen stelt aan de uitloop. Over de effecten van spreiding van zonnepanelen (in plaats van concentreren op enkele ha's) over een groter areaal landbouwgrond op de gewasproductie en het dierenwelzijn van weidende dieren, is nog onvoldoende bekend in Nederlandse omstandigheden. Nader onderzoek kan mogelijk interessante combinaties opleveren van energie en landbouwproductie, vooral omdat de technische ontwikkelingen qua typen zonnepanelen en opslagmethoden van energie zich verder zullen ontwikkelen. Tevens is het nog niet duidelijk hoe wet en regelgeving toegepast wordt bij gecombineerd landgebruik (bijvoorbeeld mestnormen en toeslagrechten). 
- Het grote scala aan combinatiemogelijkheden van landbouw en zonneparken vergt per combinatiemogelijkheid een afweging tussen hoeveelheid op te wekken duurzame energie, de schaal waarop, de mate van integratie op het erf en/of het land enerzijds en anderzijds de kwaliteit van het erf en het grondgebied voor diverse functies, daarbij rekening houdend met milieuaspecten en dierenwelzijn.

\section{Kennisleemten}

De technische ontwikkelingen van verschillende typen zonnepanelen, omvormers, aansluitingen op het elektriciteitsnet en opslagmethoden van pieken en de gehele constructie zullen toenemen. Daardoor zullen steeds weer nieuwe kansen ontstaan voor combinatiemogelijkheden tussen landbouw en energieproductie. De kennisbehoefte zal daarom in de loop der tijd veranderen en hangt af van de toepassing op een landbouwbedrijf, wat samenhangt met de mate van integratie tussen de landbouwkundige en energieleverende functie.

De kennisvragen hebben te maken met ontwerpopgaven, verdienmodellen, aanvullende beleidsvragen en gevolgen voor dieren en gewassen. Een belangrijke andere ontwikkeling is de opslag van energie om vraag en aanbod beter op elkaar af te stemmen. Een mogelijkheid is zonne-energie, eventueel gecombineerd met windenergie te verwerken tot waterstof, deze lokaal opslaan en de waterstofvoorraad aanwenden wanneer deze nodig is. Deze innovatie of andere wijzen van opslag zullen steeds belangrijker worden, maar zijn nog niet marktrijp.

\section{Ad 1. Beperkte integratie door toepassing op daken en erf}

\section{- Daken}

Bij toepassing op daken kan gedacht worden aan gebouwen voor vee, maar ook tuinbouwkassen. Welk deel van de zonnestraling wordt gebruikt voor opwekken elektriciteit, voor groei planten en voor licht in het gebouw voor dier en plant? Wat zijn de gevolgen voor opwarmen lucht in het gebouw en welke gevolgen heeft dit voor de verschillende planten en diersoorten? En zou de warmte onder panelen benut kunnen worden?

- Uitloop

Welke opstelling, zuid of oost, gecombineerd met west, past het best bij de eisen die gesteld worden aan een uitloop voor de verschillende diersoorten? Denk aan mate van openheid tussen panelen, wateropvang, bescherming tegen eventuele beschadiging door dieren (wroeten e.d.), geen stof op panelen, voorzieningen voor drinken en voeren. Wat zijn de gevolgen voor het diergedrag indien sprake is van een (deels) overkapte uitloop? Wat zijn de voor- en nadelen van lichtdoorlatende panelen voor het diergedrag?

Indien sprake is van een behoorlijke overkapping is mogelijk aanvullend beleid nodig in relatie tot milieueisen rond beperken van emissies van ammoniak, broeikasgassen en stof.

- Voer- en mestopslag

Hoe pas je zonnepanelen rond voer- en mestopslagen in zodat je minder last hebt van regenwater, pers-sappen en geen hinder hebt bij werkzaamheden?

- Op of langs paden Hoe kun je de panelen zodanig plaatsen dat je ook erfafspoeling beperkt? En hoe beperk je hinder voor machines en vrachtwagens?

Ad 2a. Integratie op grotere schaal in een zonnepark; met minimale belasting landbouw

- Langs perceelranden, op of langs sloten Welk type paneel past het best langs perceelranden? Verticaal of toch met hellingshoek? Hoe maak je verticale panelen stormbestendig? Hoe zorg je voor aansluiting op het elektriciteitsnetwerk? Bij toepassing op sloten of meren: zijn er vragen over welke constructie? Wat zijn de gevolgen voor de waterkwaliteit? Is extra elektriciteitsopwekking mogelijk door weerkaatsing licht van het water (bifacial panelen)?

- Combi met windmolens Is een combinatie mogelijk door zonnepanelen tussen windmolens (grote en kleine) te plaatsen? Hoe zorg je voor gezamenlijke aansluiting op het elektriciteitsnet? Hoe kun je gezamenlijk energie opslaan? 
Ad $2 b$. Integratie op grotere schaal in een zonnepark; met maximale energieproductie per ha

- Combi met uitloop beperkt

Zie vragen uitloop ad 1 )

- Beleidsvragen

Wat zijn de gevolgen voor verkrijgen toeslagrechten?

Wat zijn gevolgen voor bemesting?

Ad 2c. Integratie op grotere schaal in een zonnepark; optimaal combineren landbouw en energie Door zonneparken te combineren met landbouw is vergunning voor een groter gebied nodig, omdat de panelen verspreid worden over een groter gebied. Dit heeft gevolgen voor de teelt van landbouwgewassen, gedrag van dieren, de aansluiting op het elektriciteitsnet en inpassing in het landschap. Dit levert veel vragen op:

- Technisch

Welke type paneel in combinatie met zuid- of oost-/west-opstelling past het best bij welke vorm van landbouw? Denk aan verticaal, verticaal met bifacial, lichtdoorlatend, mobiel of vaste constructie waar je met machines onder door kunt rijden?

- Gewasproductie

Over de invloed van zonnepanelen op de gewasproductie is nog weinig bekend onder het Nederlandse klimaat? Nader onderzoek naar de invloed van beperken zonnestraling, veranderende waterhuishouding en microklimaat onder panelen op de gewasproductie en -kwaliteit is zinvol.

Daarbij onderscheid maken tussen typen panelen en constructies. Kan teelt onder folie ook zorgen voor extra energieproductie door weerkaatsing van het licht?

- Diergedrag

Wat is de invloed van verschillende typen panelen en constructies op het diergedrag? Hoe verandert bv. het beweidingsgedrag van melkvee? Welke voor- en nadelen biedt de schaduwwerking? 


\section{Biodiversiteit en zonneparken}

\subsection{Zonneparken als leefgebied}

In deze paragraaf wordt beschreven of soorten uit diverse diergroepen zijn waargenomen in zonneparken. In welke mate dit het geval is, wordt bepaald door het aantal parken waarin waarnemingen zijn gedaan en of zonneparken ook aantrekkelijk of geschikt zijn als leefgebied. Per soortgroep wordt aangegeven of er voldoende rapportages van waarnemingen zijn gevonden en of de waarnemingen geïnterpreteerd kunnen worden als aanwijzing dat zonneparken werkelijk leefgebied zijn.

\section{Zoogdieren}

In een gedegen review besteden Montag et al. (2016) en Harrison (2017) aandacht aan de ecologische effecten van zonneparken. Montag is een van de weinige bronnen met velddata van zoogdieren in zonneparken. Volgens Harrison zijn er verder tot en met 2016 geen serieuze studies naar zoogdieren en natuurwaarden in het algemeen in zonneparken.

Over alle acht zonneparken in Groot-Brittannië waarin batdetectors waren opgesteld was er geen verschil met de controlegebieden in het aantal soorten waargenomen vleermuizen (Montag et al. 2016). Vleermuizen vermijden zonneparken niet en worden er ook niet door aangetrokken. Wel leek de vleermuisactiviteit geringer te zijn in de zonneparken. Indien dat het geval is, kan interactie met de kunstmatig vlakke zonnepanelen een oorzaak zijn. Nader onderzoek wordt aanbevolen. Er zijn aanwijzingen dat vleermuizen panelen als wateroppervlakten waarnemen. Het lijkt echter onwaarschijnlijk dat daardoor een aanvaringsrisico bestaat. Er zijn geen studies bekend waar slachtoffers gevonden werden (Taylor, 2010; Harrison et al., 2017).

In dezelfde studie werden hazen (Lepus europaeus) in hoge dichtheden waargenomen in zonneparken. De rijen zonnepanelen leken als dekking gebruikt te worden. In zonneparken waren de dichtheden hoger dan in de controleplots, wat mede veroorzaakt kan zijn door een aantrekkelijke, gevarieerdere vegetatie daar als gevolg van het inzaaien van bloemrijke grasklavermengsels.

Ook de vos (Vulpes vulpes) werd waargenomen in de onderzochte zonneparken, evenals sporen van dassen (Meles meles). De Wiltshire Wildlife Trust (2018) volgt de ontwikkeling van de Chelworth solar farm waar ook hazen, konijnen en reeën worden waargenomen. Herden et al. (2009) noemen ook deze soorten voor zonneparken in Duitsland en bovendien nog eekhoorn (Sciurus vulgaris) en damhert (Dama dama).

Voor zoogdieren functioneren zonneparken dus als leefgebied. Als het grasland tussen en onder de panelen kruidenrijk is en veel dekking geeft, is het in potentie een aantrekkelijker leefgebied dan intensief gebruikt agrarisch gebied. Voor uitwisseling met de omgeving is het belangrijk dat het raster rond het zonnepark geen barrière is. Voor vrijwel alle soorten is het voldoende als de onderrand $10 \mathrm{~cm}$ van de grond is. Voor reeën en herten is meer nodig. Hagen of sloten als afscheiding hebben in ecologisch opzicht de voorkeur boven hekken.

\footnotetext{
Vogels

Het overzicht in deze paragraaf is vooral gebaseerd op informatie die al eerder in samenwerking tussen de WUR, Universiteit Groningen en het kenniscentrum voor akkervogels is samengebracht. Sinds november 2018 zijn er vrijwel geen nieuwe bronnen beschikbaar gekomen. Zonneparken worden door vogels gebruikt (bijvoorbeeld Herden et al., 2009; Visser, 2016; Raab, 2015; Montag et al., 2016; Sinha et al., 2018). In de technische literatuur worden 'gebruikers' in zonneparken benoemd als bron van vervuiling door vogelpoep (Lamont \& El Chaar, 2011). In studies waarin het voorkomen van vogels werd vergeleken tussen gerealiseerde zonneparken en de situatie voor de bouw van dat park of tussen zonneparken en de omgeving (referentiegebied), werden soms negatieve effecten gevonden op het aantal vogelsoorten (DeVault et al., 2014; Montag et al., 2016; Tröltzsch \& Neuling, 2013) of het aantal individuen/territoria (Heindl, 2016; Tröltzsch \& Neuling, 2013). DeVault
} 
vond dat op vliegvelden de kans op aanvaringen tussen vliegtuigen en vogels afnam als graslanden werden omgevormd tot zonneparken vanwege het geringer aantal vogels dat gebruikmaakt van zonneparken. Soms werd er geen effect gevonden op deze parameters (Visser, 2016) en soms werd er juist een positief effect gevonden op het aantal vogelsoorten (Montag et al., 2016; Lieder \& Lumpe, 2012).

Effecten van de aanleg van zonneparken kunnen positief zijn als deze worden gebouwd op intensieve landbouwgrond (Montag et al., 2016; Raab, 2015; Herden et al., 2009; Lieder \& Lumpe, 2012). Effecten van zonneparken zijn veelal negatief als deze worden aangelegd in meer natuurlijke habitats en natuurgebieden (Tröltzsch \& Neuling, 2013; Heindl, 2016). Zonneparken zijn aantrekkelijker voor vogels naar mate er meer ruimte tussen de panelen bestaat. Tröltzsch \& Neuling (2013) vonden meer nesten in zonneparken met meer ruimte tussen panelen. Positieve effecten werden ook gevonden in het geval van een extensief beheer van het zonnepark, zoals de aanleg van kruidenrijk grasland (Raab, 2015; Montag et al., 2016; Herden et al., 2009). Begrazing lijkt een overwegend negatief effect te hebben, zeker als dit jaarrond met relatief hoge dichtheden plaatsvindt waardoor de vegetatie permanent kort wordt gehouden.

In het algemeen is door de aanleg van een zonnepark een verschuiving in de samenstelling van de soorten die het gebied gebruiken te verwachten, omdat verschillende soortgroepen vermoedelijk verschillend op de aanleg van een zonnepark reageren. Akkervogels die als broedvogels in zonneparken werden aangetroffen, zijn Veldleeuwerik (Tröltzsch \& Neuling, 2013; Lieder \& Lumpe, 2012; Herden et al., 2009; Raab, 2015), Graspieper (Lieder \& Lumpe, 2012), Gele Kwikstaart (Raab, 2015), Kneu (Tröltzsch \& Neuling, 2013, Lieder \& Lumpe, 2012; Raab, 2015), Ringmus (Raab, 2015), Geelgors (Tröltzsch \& Neuling, 2013; Lieder \& Lumpe, 2012; Herden et al., 2009; Raab, 2015), Grauwe Klauwier (Heindl, 2014; Raab, 2015), Paapje (Tröltzsch \& Neuling, 2013; Heindl, 2016; Raab, 2015) en Patrijs (Herden et al., 2009; Raab, 2015). Een akkervogel die zonneparken lijkt te mijden is de Grauwe Gors (Heindl, 2016; Lieder \& Lumpe, 2012).

Roofvogels zoals Buizerd, Rode Wouw en Torenvalk werden niet als broedvogels in zonneparken aangetroffen, maar maakten wel regelmatig gebruik van zonneparken om te foerageren (bijvoorbeeld Raab, 2015; Visser, 2016; Montag et al., 2016). Er zijn verschillende aanwijzingen dat grotere vogels, met name soorten die in groepen leven (bijvoorbeeld ganzen), zonneparken weinig gebruiken (DeVault et al., 2014). Vermijden van zonneparken door grote vogels en weidevogels wordt ook door Herden et al. (2009) en Lieder \& Lumpe (2012) vermoed. Nergens is de aanwezigheid van de steltlopers onder de weidevogels in zonneparken aangetoond. Hierbij moet worden opgemerkt dat de onderzochte zonneparken niet in typische weidevogelgebieden lagen (Herden et al., 2009), maar aangezien weidevogels openheid en uitzicht prefereren, is het aannemelijk dat ze niet in zonneparken broeden.

Zonnepanelen bieden ook nieuwe nestlocaties (bijvoorbeeld Hernandez et al., 2014; Visser, 2016; Lamont \& El Chaar, 2011; Tröltzsch \& Neuling, 2013; Heindl, 2014; Herden et al., 2009). Wat Europese vogels betreft, is nestelen op de panelenconstructie zelf vastgesteld voor Kneu, Witte Kwikstaart, Zwarte Roodstaart, Grauwe Klauwier en Kramsvogel (Tröltzsch \& Neuling, 2013; Heindl, 2014; Herden et al., 2009).

Een mogelijk negatief effect van zonneparken betreft directe mortaliteit door zonnepanelen. Dit blijkt echter in slechts een aantal specifieke gevallen voor te komen. Thermische zonnecentrales die door middel van spiegels zonne-energie concentreren, lijkt niet relevant voor de situatie in Nederland/Europa te zijn (McCrary et al., 1986; Kagan et al., 2014; Walston et al., 2016). Mortaliteit van vogels is bekend van (normale) zonneparken in de woestijn. Dit betreft watervogels die zonnepanelen met wateroppervlakte verwisselen ('lake effect', Kagan et al., 2014; Walston et al., 2016). Deze vogels sterven niet direct, maar stranden al dan niet gewond binnen het zonnepark en worden daar gepredeerd (Kagan et al., 2014). Bij gedetailleerde studies in Duitsland en in het Verenigd Koninkrijk werden geen slachtoffers in zonneparken gevonden (Feltwell, 2013; Lieder \& Lumpe, 2012; Herden et al., 2009). Herden et al. 2009 observeerden ook geen landingspogingen van watervogels die over zonneparken vlogen. Ook DeVault et al. 2014 (Verenigde Staten) troffen geen aanvaringsslachtoffers aan ondanks een grote steekproef. Visser (2016) (Zuid-Afrika)) rapporteerde wél kadavers, maar de precieze doodsoorzaak en daarmee de relatie met het zonnepark was onduidelijk. 


\section{Insecten en andere ongewervelden}

Montag et al. (2016) vergeleken in Engeland waarnemingen van hommels en vlinders tussen transecten binnen zonneparken met transecten in controlegebieden. Over alle 29 zonneparken en 21 controlegebieden waren er geen significante verschillen in soortenrijkdom. De dichtheid aan vlinders en hommels was echter significant hoger in zonneparken, vooral dankzij de ingezaaide bloemrijke vegetaties. Het onderzoek vond kort na de aanleg plaats. De vegetatie heeft tijd nodig om zich te ontwikkelen en dat geldt ook voor de insectenfauna. Dagvlinders zijn sterk afhankelijk van bloemrijke vegetaties en het voorkomen van specifieke waardplanten. In vijf in 2013 onderzochte zonneparken in Duitsland (Raab, 2015) was het opvallend hoe snel na aanleg een groot aantal vinders en vlindersoorten werd waargenomen. Net als in Engeland werden bloemrijke mengsels ingezaaid op voormalige akkers. Een belangrijke factor in Duitsland was de nabijheid van rijke bronpopulaties in kalkrijke schrale graslanden. In Frankrijk is onderzocht of zonneparken een barrière zijn voor de uitwisseling van graslandvlinders tussen leefgebieden (Guiller et al., 2017). Voor de mobielste vlindersoorten leek dit niet het geval te zijn. Voor de plaatstrouwe soorten, die het meest afhankelijk zijn van ecologische verbindingen, leverde het onderzoek geen significant resultaat op. In het algemeen kan men stellen dat als de inrichting en het beheer van zonneparken zorgen voor de instandhouding van bloem- en kruidenrijke vegetaties, dit belangrijke leefgebieden kunnen zijn die een bijdrage leveren aan ecologische verbindingen tussen natuurgebieden.

Sprinkhanen en krekels zijn afhankelijk van directe zonbestraling. Voor zover de bodem en de vegetatie deels of geheel beschaduwd wordt, zal een zonnepark dus nauwelijks functioneren als leefgebied (Herden et al., 2009). Dit geldt zowel voor droge als vochtminnende soorten. Anderzijds zijn er stroken tussen de rijen waar wel zon komt en is het microklimaat in zonneparken aantrekkelijk voor deze soortgroep (Armstrong et al., 2016). Herden et al. (2009) vonden in drie onderzoeksgebieden in zonneparken veertien soorten waaronder vier vermeld in de Duitse Rode Lijst.

In de Duitse zonneparken en in referenties daarbuiten zijn met kleefstroken steekproeven genomen van de overige insectenfauna. Doel was te onderzoeken in hoeverre de vangsten binnen de zonneparken afwijken van die daarbuiten. Het aantal gevangen individuen was het hoogst op de stroken die het dichtst bij landbouwgewassen opgehangen waren. De referenties weken niet fundamenteel af van de waarnemingen in de zonneparken (Herden et al., 2009).

\section{Amfibieën en reptielen}

Nog minder dan aan vogels en insecten vindt er onderzoek aan amfibieën en reptielen plaats in zonneparken. In Groot-Brittannië (BRE., 2014) zijn, naast algemene kikkers en padden, kamsalamanders vastgesteld in poelen in zonneparken. $\mathrm{Er}$ is ook geen reden om te veronderstellen dat poelen in zonneparken niet op zijn minst een even goed leefgebied voor amfibieën zouden zijn als poelen in het gangbare agrarisch gebied. Poelen in zonneparken kunnen bovendien gemakkelijker omgeven zijn door extensief gebruikt kruidenrijk grasland, omdat de agrarisch productie ondergeschikt is. De waterkwaliteit kan daardoor hoog zijn, in tegenstelling tot poelen met instroom van nutriëntrijk water vanaf landbouwpercelen. Als landhabitat kunnen zonneparken zowel koeler en vochtiger microklimaat bieden als een door beschutting warmer leefgebied. Voorwaarden voor een ecologisch goede poel is wel dat er voldoende zonbeschenen plekken in de poel zijn.

In de Amerikaanse literatuur is aandacht voor habitatvernietiging van reptielen in (semi)woestijnomgevingen door de aanleg van zonneparken en thermische zonne-energiecentrales. Voor Nederland is dit niet aan de orde, omdat bij de huidige regelgeving in natuurgebieden zoals de duinen (met b.v. zandhagedis) en heidevelden (met o.a. gladde slang en adder) geen zonneparken worden gerealiseerd. Op schrale bodems hebben zonneparken potentie als leefgebied voor reptielen. Het is met reptielen echter net als met sprinkhanen en krekels: er moet vooral voldoende zonbeschenen bodem overblijven. Levendbarende hagedissen worden veelvuldig op de zonnepanelen waargenomen.

\section{Aquatische organismen}

Verrassend genoeg blijken effecten van zonnepanelen op waterinsecten goed onderzocht. Zonnepanelen reflecteren gepolariseerd licht en lijken daardoor op watervlaktes (zoals ook andere artificiële structuren zoals glas- en asfaltvlakten; Horváth et al., 2009, 2010). Het blijkt dat waterinsecten sterk worden aangetrokken door zonnepanelen, o.a. voor de eileg (Horváth et al., 
2009; Herden et al., 2009). Panelen worden zelfs geprefereerd boven watervlaktes. Panelen werken op deze manier als val, maar tot dusver is er geen onderzoek gedaan naar effecten op populatieniveau. Száz et al. (2016) benadrukken wel het 'potential to negatively impact their global populations [of aquatic insects] as solar energy expands'.

Aantrekkingskracht van panelen op waterinsecten kan verminderd worden door witte strepen op de panelen aan te brengen. Kleine strepen (1,8\% van oppervlakte) blijken voldoende (Horváth et al., 2010). Matte panelen met antireflectieve coatings blijken niet te helpen (alleen onder bepaalde weersomstandigheden en voor bepaalde soortgroepen; Száz et al., 2016). Daarnaast wordt aanbevolen zonneparken niet te dicht bij watervlaktes te plaatsen (Száz et al., 2016), waarbij niet wordt aangegeven welke minimale afstand tot water aangehouden zou moeten worden.

Andere insecten dan waterinsecten zouden ook door het gereflecteerde gepolariseerde licht aangetrokken of anderszins beïnvloed kunnen worden, bijvoorbeeld hommelachtige of andere visueel ingestelde insecten, maar hierover werd geen informatie gevonden.

\section{Flora en vegetatie}

Beschaduwing en graafwerk ten behoeve van leidingen en andere infrastructuur zijn desastreus voor bijzondere vegetaties. Het is vanzelfsprekend dat zonneparken in een schraal grasland of heidegebied uit natuurbeschermingsoogpunt ongewenst zijn. Uit Duits onderzoek (Tröltzsch \& Neuling, 2013; Heindl, 2014) aan zonneparken gerealiseerd op schrale graslanden in voormalige militaire oefenterreinen blijkt dat de vegetaties in de niet afgedekte $5 \mathrm{~m}$ tussen de panelentafels nog wel aantrekkelijk is voor bv. het paapje als het goed wordt beheerd. Het moet dan ook wel bloemrijk zijn geweest. Vegetatiekundig moet het deel onder de panelen echter als verloren worden beschouwd. Montag et al. (2016) vergeleken systematisch de botanische soortenrijkdom in zonneparken gerealiseerd op voormalige akkers met controlegebieden. Zij concluderen dat het met actief beheer mogelijk is een grotere botanische diversiteit te realiseren, zowel in grassen als kruiden, dan in het gangbare landbouwgebied. De verwachting kwam uit dat dit met het inzaaien van kruidenrijke mengsels mogelijk is. Omdat dit resultaat eigenlijk een open deur is, blijft botanisch onderzoek meestal achterwege in zonneparken. Het is echter de moeite waard ook dit soort onderzoek te doen om zekerheid te krijgen over welke vegetatietypen wel of niet haalbaar zijn. Hierbij dient vooral ook gelet te worden op de praktische mogelijkheden om op verschillende tijdstippen en met verschillende frequenties te maaien of te begrazen. De stellages leggen hieraan beperkingen op. De belangrijkste beperking voor de vegetatie is het gebrek aan direct zonlicht gedurende een groot deel van de dag. Niet alleen onder de panelen, maar ook tussen op het zuiden gerichte rijen. Echt zonminnende planten zullen daarom niet goed gedijen. Voor schaduwminnende planten, vooral bosplanten, zijn zonneparken een goede standplaats, mits het regenwater ook onder de panelen op de bodem kan druppen.

\subsection{Beheer zonneparken voor biodiversiteit}

Bij het ontwerpen en plannen van zonneparken is vaak weinig aandacht voor het beheer na realisatie van het zonnepark. Het zou goed zijn als daar bij het ontwerp al meer rekening mee zou worden gehouden. Sommige provincies (o.a. Groningen) stellen als randvoorwaarde dat een deel van de grond $(10 \%)$ moet worden beheerd als natuur door inzaaien van kruiden en voor akkervogels. Maar met het inzaaien alleen ben je er niet. Vegetaties zoals bloemrijk grasland of bloemrijke akkers vergen elk jaar opnieuw het juiste beheer. Intensief gebruikt landbouwgebied is leefgebied voor slechts een klein aantal soorten. Het belang hiervan voor behoud van biodiversiteit in Nederland is eigenlijk alleen groot voor overwinterende vogels zoals ganzen en zwanen. Weidevogels, akkervogels en een groot aantal insecten en andere kleine diersoorten hebben zich aangepast aan extensief gebruikt agrarisch gebied en zijn nu sterk afgenomen, doordat extensief gebruikte landbouwpercelen eigenlijk alleen voorkomen in natuurgebieden of agrarische randgebieden die op het punt staan te verdwijnen. Zeker voor een groot aantal vlinders, bijen, hommels, loopkevers et cetera geldt dat ze in potentie leefgebied zouden kunnen vinden in zonneparken. Een voorwaarde is wel dat het gras binnen de hekwerken niet intensief en continu wordt begraasd door schapen (Montag et al., 2016; Raab, 2015; Herden et al., 2009). Er moet zich een bloem- en kruidenrijke vegetatie kunnen ontwikkelen die gefaseerd in ruimte en tijd wordt gemaaid of begraasd (bv. één maand begrazen, twee maanden rust). Omdat een verschraalde bodem gunstig is voor de ontwikkeling van grasland rijk aan biodiversiteit, dient het maaisel altijd te worden afgevoerd. Om deze reden mag ook geen mest 
worden aangewend binnen een zonnepark. Grasland binnen zonneparken wordt dan eigenlijk als grasland in een natuurgebied beheerd. Ook akkervogels vestigen zich in zonneparken als daarin vogelakkers worden aangelegd en in stand gehouden. De potenties zijn erg afhankelijk van de locatie en de uitgangssituatie. In het algemeen kun je stellen dat met planmatig beheer de biodiversiteit van zonneparken veel hoger kan zijn dan in gangbaar gebruikt agrarisch gebied.

Voor de verzekering is het vaak noodzakelijk het zonnepark geheel of gedeeltelijk te voorzien van een raster. In landschappelijk opzicht is dit niet aantrekkelijk. Een goed alternatief kan zijn het aanplanten van struweelhagen. In struweelhagen kan zich een rijke biodiversiteit ontwikkelen, zeker als deze grenst aan natuurgrasland. Meest waardevol is een breed uitgroeide haag van een paar meter hoog die om de 5-7 jaar wordt teruggezet. Hagen die jaarlijks geschoren worden, herbergen duidelijk minder organismen. In gebieden met een hoge waterstand zijn sloten met een natuurvriendelijk beheerde oever een waardevol alternatief voor rasters of hagen, vooral in open landschappen waarin weidevogels voorkomen en opgaande landschapselementen door hun beslotenheid de weidevogels afschrikken. Het is nog niet bekend hoe rijen zonnepanelen worden ervaren door boerenlandvogels. Soorten als veldleeuwerik, scholekster en patrijs laten zich niet afschrikken en blijken een zonnepark te gebruiken. Voor een aantal boerenlandvogels biedt dit mogelijk perspectief, omdat in agrarisch gebied waar nog wel gebroed wordt, voedsel voor kuikens in de vorm van insecten erg schaars is. Of doorgaans sterk aan open landschap gehechte soorten als kievit en grutto de sprong naar zonneparken kunnen maken, is niet bekend, maar lijkt onwaarschijnlijk. Indien dit het geval is, kunnen zonneparken grenzend aan open landschappen met weidevogels beter niet van rasters of hagen maar van sloten voorzien worden. Worden zonnetafels net als bosjes, gebouwen en riet ook als bedreigend ervaren, dan zijn zonneparken niet gewenst in de bufferzone (200-300 m) van weidevogelkerngebieden. Het beheer van de zonneparken doet dan voor deze soorten niet ter zake.

\subsection{Natuurbeschermingsdoelen van zonneparken}

In het Rijks Natuurbeleid staan de Europees beschermde soorten centraal en het halen van de doelen van uit de beheerplannen van de Natura 2000-gebieden. Vanwege deze bescherming worden er zelden plannen gemaakt om zonneparken te realiseren in Natura 2000-gebieden op land. Daar waar bijvoorbeeld ganzen en zwanen in de doelstelling genoemd worden, komen de akkers en graslanden die zij gebruiken dus niet in aanmerking voor een zonnepark. Het is immers niet waarschijnlijk dat ganzen en zwanen in de zonneparken voedsel gaan zoeken. Observaties van hun reactie zijn er nog niet. Bovendien hebben deze soorten productieve graslanden nodig. Bij afdekking van de grond met zonnepanelen verdwijnen deze. Waar het in de Natura 2000-gebieden gaat om natuurlijk grasland of beschermde habitattypen is realisatie van een zonnepark helemaal kansloos, omdat een zonnepark dan onvermijdelijk tot verlies aan oppervlakte zal leiden. Een deel van de vogel- en habitatrichtlijnsoorten komt voor een belangrijk deel buiten het Natura 2000-netwerk en zelfs buiten het Nationaal Natuurnetwerk (NNN) voor. In het proces voor het verlenen van een omgevingsvergunning moet altijd worden nagegaan of in het plangebied Europees beschermde soorten voorkomen en of die significant benadeeld kunnen worden. De ontwikkeling en het beheer van het NNN is gedelegeerd aan de provincies. Doorgaans kan voor het zonnepark binnen Natura 2000netwerk of in het NNN geen vergunning worden verleend, omdat dit bijna altijd ten koste van de oppervlakte van belangrijke natuurtypen zal gaan.

Buiten de Natura 2000-gebieden en het NNN liggen nog agrarische gebieden waar natuurbeheersmaatregelen worden uitgevoerd ten behoeve van soorten gebonden aan agrarisch cultuurlandschap. In het provinciaal beleid worden deze gebieden als kerngebieden voor weide- of akkervogels aangeduid. Op voorhand is het uitgangspunt dat dit doel meestal niet te verenigen zal zijn met een zonnepark. Alleen als kan worden aangetoond dat deze soorten juist profiteren van de aanleg en doelgericht beheer van een zonnepark kan er ruimte zijn voor deze ontwikkeling.

Met als uitgangspunt dat zonneparken niet in (agrarische) natuurgebieden worden gerealiseerd waar dit ten koste gaat van beschermde soorten, is het vooral de vraag welk natuurdoel bediend kan worden in een zonnepark. Welk natuurdoel is te combineren met een zonnepark? Veel is mogelijk, maar wat is wenselijk? De Rijksnatuurdoelen en de doelen van het NNN zijn te karakteriseren als top- 
down bepaalde doelen die door de overheid bewaakt worden. In de samenleving is echter ook draagvlak voor behoud van biodiversiteit in het algemeen. Lang niet voor alle wilde soorten in Nederland is het duurzaam voorkomen verzekerd met dit top-down beleid. Er wordt door het Planbureau voor de Leefomgeving (PBL) een ernstige afname van het aantal dagvlinders, libellen, boerenlandvogels en amfibieën vastgesteld. Het aantal algemene insecten is ook sterk afgenomen. $\mathrm{Er}$ is dus veel voor te zeggen om ook buiten de (agrarische) natuurgebieden de variatie aan wilde planten en dieren te bevorderen. De overheid zal dit echter niet op basis van de wet kunnen afdwingen. Maar een provincie of gemeente zou wel kunnen aansturen naar een optimum tussen maximale energielevering en winst voor biodiversiteit. Dus wat minder panelen en wat meer licht op de bodem. Het is belangrijk als natuurdoelen bottom-up door betrokken burgers benoemd worden. In een dichtbevolkt land als Nederland waar de ruimte voor functies als recreatie, natuur en landschapsbescherming schaars is, is multifunctioneel grondgebruik ook het meest gewenst. De ontwikkelaar van een zonnepark zou het recht om een zonnepark op te richten mede moeten verwerven op basis van een meerwaarde voor de samenleving, bovenop de al zeer gewenste productie van duurzame energie. Een analogie met de zand- en grindwinningsector is mogelijk waar nieuwe vergunningen voor een winning door de provincie alleen worden verleend als middel om een doel als natuurontwikkeling of recreatie te realiseren. Multifunctioneel grondgebruik, waarbij energiewinning wordt gecombineerd met natuur en recreatie, is ruimtegebruik waarvan je geen op termijn geen spijt zult krijgen.

\section{BOX Natuurvisie}

In de natuurvisie van de rijksoverheid beschrijft het kabinet in grote lijnen het natuurbeleid voor de komende jaren, tot 2025. Belangrijkste punt van de visie is een omslag in het denken en niet alleen in beschermde natuurgebieden. Centraal in de natuurvisie staat dat natuur midden in de samenleving thuishoort. Want de natuur die mensen belangrijk vinden, is veel meer dan de natuur in beschermde natuurgebieden. De natuurvisie wil vooral burgers, bedrijven, gemeenten en maatschappelijke organisaties meer kansen bieden om natuur te beschermen. De natuurvisie verlegt de aandacht: van bescherming van natuur tegen de samenleving naar versterking van natuur door de samenleving. Voor een betere natuur hebben burgers en bedrijven ook een verantwoordelijkheid te nemen. Volgens de natuurvisie kunnen economie en natuur goed samengaan en van elkaar profiteren. Bedrijven houden steeds meer rekening met natuur en biodiversiteit. Dit heet ook wel groen ondernemerschap. Zonder duurzame productie kunnen bedrijven op den duur niet meer concurreren op de wereldmarkt. Een voorbeeld is de inspanning van grote ondernemingen om de productie van palmolie te verduurzamen. Het programma Tweede Natuur komt voort uit de natuurvisies van de rijksoverheid en provincies. Dit programma richt zich op ideeën uit de samenleving. De ideeën laten zien hoe natuur kan samengaan met maatschappelijke en economische activiteiten. Hierbij is onder andere gedacht aan de functiecombinaties van natuur met energie.

Het kiezen van niet bij wet afgedwongen natuurdoelen voor zonneparken is maatwerk. Het maatwerk moet ervoor zorgen dat de economische opbrengst voor de ontwikkelaar of exploitant voldoende is, dat er draagvlak is voor de betrokkenen om het noodzakelijke beheer uit te voeren en de effecten te volgen (vrijwilligers!) en dat de meerwaarde ook echt als zodanig wordt ervaren. De doelen moeten ook haalbaar zijn op basis van bodem, waterhuishouding en landschap en moeten passen bij de omgeving. Om ervoor te zorgen dat het beheer ook werkelijk wordt volgehouden, kan dit het best in een biodiversiteitsmanagementplan uitgewerkt worden waarin de maatregelen en verantwoordelijkheden worden vastgelegd. Verantwoordelijkheden die overgaan op nieuwe eigenaren en beheerders bij verkoop. 


\subsection{Ruimtelijke aspecten van zonneparken voor biodiversiteit}

De ligging van een locatie voor een zonnepark bepaalt de geschiktheid voor een natuurdoel. Op droge, voorheen zwaar bemeste kleigrond is het niet mogelijk een vochtig, voedselarm schraal grasland te ontwikkelen. Dat is één ruimtelijk aspect. Het is daarnaast belangrijk bij de keuze van de natuurdoelen aan te sluiten op natuurwaarden die in het nabij of naastgelegen perceel al aanwezig zijn. Vanuit bestaande populaties zijn zonneparken die goed beheerd worden dan gemakkelijk te koloniseren. De draagkracht van het natuurgebied kan ermee worden verhoogd. Een derde aspect is de mogelijke functie van voor biodiversiteit beheerde vegetaties in een zonnepark als verbinding, stapsteen, voor individuen van soorten om van het ene naar het andere gebied te trekken. Veel natuurgebieden in ons agrarisch cultuurlandschap zijn als geïsoleerde eilanden in een voor overleven ongeschikte omgeving. Plekken of stroken tijdelijk geschikt leefgebied in zonneparken kunnen dienen als verbindingsweg voor soorten in natuurgebieden.

Ten behoeve van een functionele biodiversiteit in het agrarisch gebied, denk aan bestuivende insecten en natuurlijke vijanden van plaagsoorten in landbouwgewassen, is het gewenst een fijnmazig aaneensluitend netwerk van groene landschapselementen, zoals schrale grasbermen, struweelhagen, natuurlijke sloten, e.d. te hebben in het agrarisch gebied. Dit is lang niet altijd aanwezig. Zonneparken kunnen hierbij een belangrijke, ondersteunende rol vervullen, omdat het gebruik van de niet door panelen afgedekte grond vrij extensief kan zijn.

Ten slotte bieden zonneparken kansen voor de ontwikkeling van hydrologische bufferzones rond natuurgebieden. Veel natte natuurgebieden verdrogen. Het is gewenst de grondwaterstand in een wijde omgeving hoog te houden. Deze wens bijt vaak de agrarische functie van de in de bufferzone gelegen percelen. Wanneer deze percelen als zonnepark worden ingericht, is een hoger grondwaterpeil niet zo'n probleem. Een bufferfunctie is ook mogelijk bij voedselarme natuurgebieden die te maken hebben met het inwaaien of binnenstromen van meststoffen of bestrijdingsmiddelen.

\subsection{Zonnepanelen op water}

Drijvende zonneparken is een relatief nieuwe uitvoeringsvorm van grootschalige opwekking van zonnestroom. In de Roadmap PV Systemen en Toepassingen (Folkers et al., 2017) wordt wereldwijd een exponentiële ontwikkeling geconstateerd en is de prognose dat er in 2023 al 2000 MWp (zeg plusminus 2000 ha) cumulatief opgesteld vermogen zal zijn. Voor de potentiële uitrol van PV in Nederland per locatie, wordt rekening gehouden met een oppervlakte op binnenwater van 13300 ha en 25000 ha op zee in 2050. Ter vergelijking: voor agrarisch terrein gaat men uit van 32500 ha, voor de gebouwde omgeving van 51600 ha en voor infrastructuur van 18400 ha.

De belangrijkste motivatie voor deze toepassing is de schaarste aan geschikt en beschikbaar land voor zonneparken. Wateroppervlaktes zoals irrigatiebekkens, baggerdepots, zandwinplassen en bassins bij zuiveringsinstallaties kunnen ingezet worden voor opwekking van zonne-energie. Een andere manier om waterareaal in te zetten, is door middel van nieuw gecreëerde eilanden (bv. in het Markermeer) met diverse bestemmingen, waaronder zonne-energie. Op de langere termijn zullen ook zonneparken op zee technisch en economisch haalbaar worden, bijvoorbeeld in combinatie met offshore windparken.

Interessante aspecten van 'zon op water' zijn daarnaast:

- Zon op water zal gemiddeld grootschaliger uitgevoerd kunnen worden dan zon op land. Dit brengt een kostenvoordeel met zich mee.

- Zon-op-waterprojecten zullen in het algemeen op minder maatschappelijke weerstand stuiten. Zeker in die gevallen waar de aanleg van een drijvend zonnepark niet strijdig is met mogelijk andere functies van het betreffende water.

- Zon op water kan een hogere stroomopbrengst opleveren. Aspecten die hierbij een rol spelen, zijn: natuurlijke koeling van de panelen, reflecties van licht aan het wateroppervlak en hogere instraling boven water vergeleken met boven land.

- Zon-op-waterprojecten zullen relatief vaak uitgevoerd worden op locaties waar ook windenergie wordt opgewekt. Aangezien zonne-energie en windenergie in hoge mate complementair zijn in de tijd, kan hiermee een effectiviteitsvoordeel behaald worden wat betreft de investering in de benodigde elektrische infrastructuur. 
Globaal zijn er twee systemen te onderscheiden:

1. Drijvende pontons waarop eenzijdig werkende panelen bevestigd zijn. Deze dekken het wateroppervlak volledig af waardoor er weinig licht meer in het water doordringt. De panelen op bijgaande foto hebben een oost-west- oriëntatie.

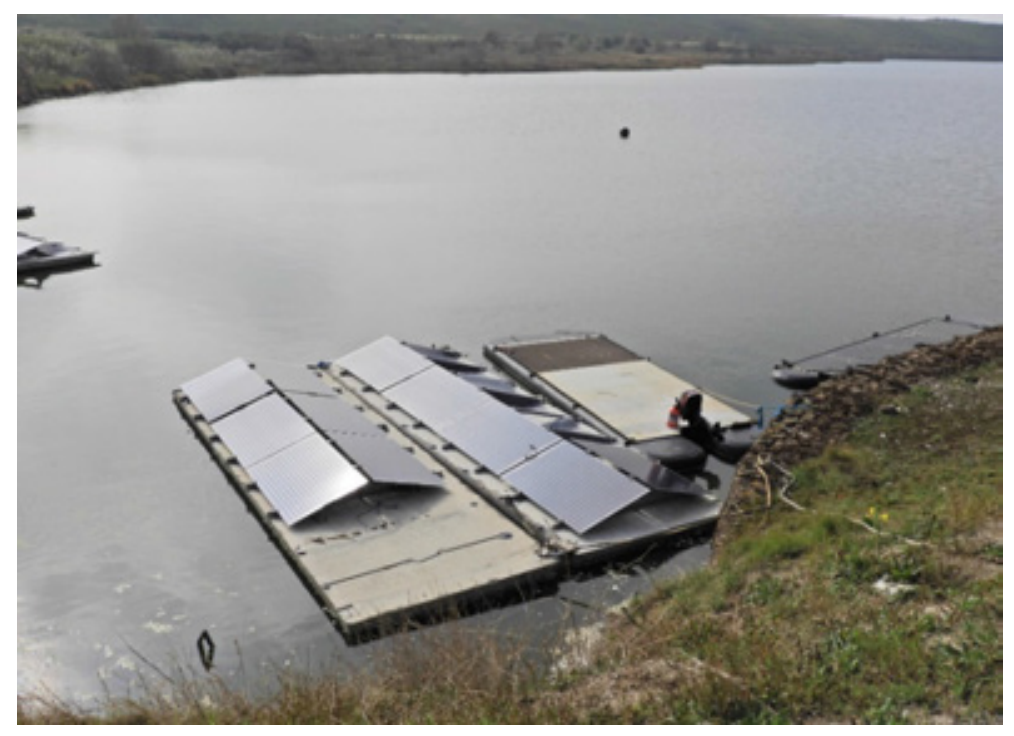

Figuur 21 Proefopstelling drijvende zonnepanelen in de Slufter, $2^{e}$ Maasvlakte (foto: Friso van der Zee).

2. Tweezijdig werkende zonnepanelen hebben aan de achterkant geen witte of zwarte folie, maar een glasplaat of een transparante folie. De zonnecellen ín de panelen zijn zo gemaakt dat ze bijna net zo efficiënt licht via de achterkant in elektriciteit kunnen omzetten als licht dat - zoals gebruikelijk - van de voorkant komt. Daardoor kunnen de panelen ook het licht benutten dat door het wateroppervlak of de grond wordt gereflecteerd en normaliter verloren gaat. "Het is een slimme en voor de hand liggende oplossing. Je gebruikt licht dat er al is en krijgt zo voor ongeveer hetzelfde geld een aanzienlijk hogere opbrengst aan zonne-energie. Op jaarbasis kan dat tientallen procenten aan opgewekte elektriciteit schelen", zegt professor Wim Sinke, Manager Programmaontwikkeling Zonne-energie bij ECN.

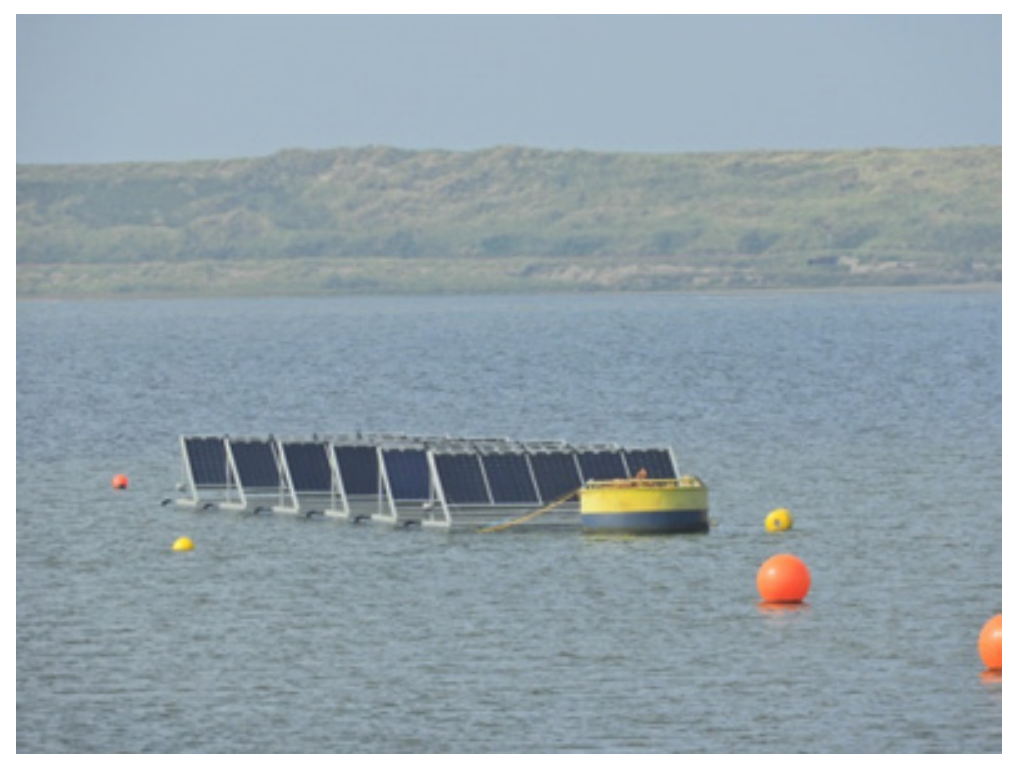

Figuur 22 Proefopstelling drijvende zonnepanelen in de Slufter, $2^{e}$ Maasvlakte (foto: Friso van der Zee). 
Het plaatsen van zonnepanelen op oppervlaktewater biedt kansen: het oppervlak is groot, de concurrentie met landbouw is laag en door reflectie van zonlicht door het wateroppervlak kan ook de efficiency hoger worden. Er zijn nog wel onduidelijkheden, zoals: wat zijn de ecologische gevolgen, hoe verloopt het onderhoud van watergangen, welke constructies zijn nodig? Systemen op water staan altijd onder invloed van beweging van het water. Dit veroorzaakt meer slijtage dan zonneparken op land. Zonnepanelen op water vereisen dus sterkere constructies die bestand zijn tegen met name extreme weersomstandigheden en dit geldt helemaal voor zonneparken op zee. Ook moet er rekening mee gehouden worden dat het materiaal waarop de constructie drijft niet afbrokkelt (piepschuim) en milieuvervuiling veroorzaakt.

Er is nog vrijwel geen literatuur over drijvende zonneparken beschikbaar. Arcadis heeft een quickscan gemaakt voor een te realiseren drijvend zonnepark in de Noorder IJplas, een voormalige grondwinplas in Amsterdam-Noord met een wateroppervlak van circa 65 ha en 20-30 m diep (Groen \& Lysen, 2018). Het park wordt ca. 3 ha groot en komt te liggen op het diepe deel van de plas. Het betreft een zonnepark met tweezijdige panelen. De conclusie van de quickscan is dat het zonnepark geen negatieve invloed heeft op de biodiversiteit en dat ook de waterkwaliteit geen negatieve effecten ondervindt. Biodiversiteitsaspecten die een rol spelen:

- Macrofauna. De aanwezige macrofauna wordt niet beïnvloed door verstoring. Door schaduwwerking kan het temperatuurpatroon in de plas veranderen wat effect kan hebben, maar dit is niet per definitie een negatief effect.

- Vissen. Vissen kunnen panelen gebruiken om onder te schuilen. Geen of een positief effect verwacht.

- Fytoplankton. Gemiddeld zal het overdag koeler zijn onder de panelen, 's nachts warmer (geen afkoeling aan de lucht). Het gaat om maximaal 5\% van het wateroppervlak, er wordt geen effect verwacht.

- Aanhechtingsmogelijkheden voor macrofauna aan de onderkant van de drijvers. Veel dieren die in het water leven, hebben 'substraat' nodig, waaraan ze zich kunnen hechten. Dat kan een zandige bodem zijn of de stengels van waterplanten of wortels van oevervegetatie. Sommige soorten, zoals mosselen, hechten zich aan 'hard substraat'. Dat kan een steen zijn, maar ook kabels, wrakken of iets anders. Niet ieder materiaal is geschikt. Onderzocht zou kunnen worden of de onderzijde van de drijvende constructie ruw gemaakt kan worden en kan fungeren als aanhechtingsplek voor bijvoorbeeld mosselen. Mosselen filteren het water en bieden weer substraat voor andere organismen en kunnen zo bijdragen aan de waterkwaliteit.

- Drijvende matten aan de buitenste rand van het zonneveld. Er zijn drijvende matten op de markt, waarop oevervegetatie kan groeien. Deze vegetatie wortelt in het water, zodat onder water habitat ontstaat voor macrofauna, maar ook voor vis. Dergelijke matten kunnen bijdragen aan de biodiversiteit in dieper water, waar geen onderwatervegetatie is. Boven water bieden deze matten leefgebied voor insecten (ook insecten waarvan de larven onder water leven, zoals libellen), waarvan vogels en vleermuizen ook weer kunnen profiteren. Dit idee is ook uitgangspunt voor de plannen voor het Lingemeer (K3Delta).

De IJsselmeerprovincies Flevoland, Friesland, Noord-Holland en Overijssel hebben het initiatief genomen om een verkenning uit te voeren naar de mogelijkheden voor zonnepanelen op water als input voor het opstellen van de Regionale Energie Strategieën voor het voorgenomen Klimaatakkoord. (https://solarmagazine.nl/nieuws-zonne-energie/i17800/energieverkenning-ijsselmeergebied-ruimtevoor-duizenden-hectare-zonnezandbanken-en-zonne-eilanden). Uit die verkenning zou blijken dat in het IJsselmeergebied ruimte is voor vele duizenden hectare zonnepanelen in de vorm van zonnezandbanken en zonne-eilanden. Het IJsselmeer is echter een Natura 2000-gebied, waar veel watervogels nu al gebrek hebben aan voedsel. Bij zulke grootschalige plannen zal uitgezocht moeten worden wat het verlies aan oppervlakte open water voor consequenties heeft voor het voedselaanbod en de beschikbaarheid daarvan voor bv. meeuwen en sterns. Natuurgebieden (N2000, NNN) worden door ruimtelijk beleid en natuurwetgeving in principe uitgesloten van zonneweides, maar dit heeft deze verkenning niet in de weg gestaan. 


\subsection{Conclusies en kennisleemten}

- Er liggen volop kansen voor biodiversiteit op zonneparken en zeker in intensief agrarisch gebied zou een zonnepark kunnen bijdragen aan de verhoging van de biodiversiteit. De kansen zijn er vooral voor vegetatie, insecten en een aantal vogelsoorten.

- Cruciaal voor een combinatie zonnepark-biodiversiteit is dat er voldoende licht en water op de bodem blijft komen. Dat lukt niet indien alleen naar maximale energieproductie wordt gestreefd. Er dient dus gezocht te worden naar een optimum tussen maximale energieproductie en biodiversiteit.

- Het beheer na realisatie van het zonnepark is essentieel voor het realiseren van natuurwaarden en zou direct bij het ontwerp meegenomen moeten worden om biodiversiteitsdoelen daadwerkelijk te halen. Dat gebeurt nu nog te weinig.

- Zonnepanelen op het water zijn zeker kansrijk en hebben minder nadelen (verlies landbouwgrond, beleving landschap) dan zonnepanelen op land.

- Tweezijdige panelen die het wateroppervlak niet volledig afdekken, hebben ecologisch gezien de voorkeur boven enkelzijdige panelen op pontons die het wateroppervlak afsluiten van licht.

- Er zijn diverse mogelijkheden om bij zonnepanelen op water constructies aan te brengen die de biodiversiteit kunnen verhogen. Dit zou nader onderzocht kunnen worden.

- Bij grootschalige projecten zonnepanelen op water zal het effect op de voedselbeschikbaarheid voor watervogels onderzocht moeten worden.

\section{Kennis vergaren over zonneparken als leefgebied}

Afgezien van een zonnepark als bedreiging van natuur als ze in (agrarische) natuurgebieden gerealiseerd worden, lijken er vooral kansen te zijn voor ontwikkeling van meer biodiversiteit, met name wanneer het gaat om nu intensief gebruikt agrarisch gebied. Dat is $70 \%$ van Nederland. Bij voormalige vuilstortplaatsen, braakliggend industrieterrein, slibdepots e.d. moet van geval tot geval beoordeeld worden of het gebied op een natuurgebied lijkt en of er beschermde soorten voorkomen. Dit is een toets die de bestaande regelgeving voorschrijft.

Er zijn kansen, maar hoe die het best op een efficiënte en effectieve manier benut worden, is niet bekend. Bij veel zonneparken worden op vrijwillige basis al maatregelen genomen ter bevordering van de biodiversiteit. Bloemrijke mengsels worden ingezaaid, hagen aangeplant en poelen of rietstroken aangelegd. Maar dit soort maatregelen kan alleen succesvol zijn als tegelijkertijd het juiste vervolgbeheer wordt bepaald en afgesproken. Ook wordt het effect van deze maatregelen, en of de doelen van deze maatregelen goed gekozen zijn, zelden onderzocht. We ontwikkelen daardoor geen ervaringskennis die we kunnen delen ten behoeve van een betere praktijk in de toekomst.

Er zijn veel doelen mogelijk, er zijn veel verschillende uitgangssituaties en de eigenschappen van zonneparken: hoogte, expositie, hellinghoek, bedekking, beheer etc. verschillen sterk. Of een maatregel voor een van de vele diergroepen effectief is, hangt sterk van al deze factoren af. De enige manier om een vinger te krijgen achter wat effectieve maatregelen zijn, is om biodiversiteitsdata en eigenschappen van een groot aantal zonneparken te verzamelen, gedurende langere tijd, om die op termijn te kunnen analyseren. De veranderingen in de biodiversiteit in Nederland worden gevolgd via het Netwerk Ecologische Monitoring (NEM). In het NEM spelen vrijwilligers een belangrijke rol. De systematische waarnemingen worden opgeslagen in landelijke databases. De waarnemers volgen jaar op jaar op vaste locaties het wel en wee van de door hen bestudeerde soortgroep. Deze locaties vallen echter niet samen met zonneparken, misschien op termijn bij een sterk uitbreiding wel, maar nu nog niet. Om op korte termijn via dit meetnet inzicht te krijgen in de invloed en mogelijkheden van zonneparken, is het gewenst gericht systematisch waarnemingen te doen in zonneparken. Hierbij dienen dezelfde gestandaardiseerde waarneemmethoden te worden toegepast. Onder die voorwaarde zijn de waarnemingen binnen de zonneparken te vergelijken met de waarnemingen daarbuiten, in een verder vergelijkbare situatie. Om te stimuleren dat in zonneparken gericht waarnemingen worden gedaan, is het gewenst dat de overheid dit stimuleert. Betrokkenheid van vrijwillige natuurwaarnemers bij de ontwikkeling van een zonnepark bevordert bovendien het draagvlak hiervoor. 
Het is nodig gericht kennis te ontwikkelen over hoe zonneparken kunnen bijdragen aan specifieke doelen voor biodiversiteit. Enerzijds door het op grote schaal verzamelen van data, anderzijds door gericht experimenten te doen. Belangrijke variabelen die geoptimaliseerd kunnen worden, zijn:

- De afstand tussen de zonnetafels in verband met de aantrekkelijkheid als broedgebied voor vogels van open landschappen;

- De breedte van de zonnetafels;

- De afstand tussen de panelen, horizontaal in verband met het afstromen van regenwater, en verticaal, als lichtbron voor de vegetatie onder de panelen;

- De hoogte en hellingshoek van de tafel in verband met de hoeveelheid voor de fotosynthese bruikbaar licht, direct en diffuus, op de bodem onder de panelen;

- De expositie, zuid of oost-west, in verband met het aandeel van de bodem waar licht en regenwatertoevoer onvoldoende zijn voor een gezond bodemleven;

- De transparantie van de panelen;

- Het type panelen, bifacial eventueel verticaal opgesteld, met de zon meebewegende panelen;

- Bij zonnepanelen op water gaat het bijvoorbeeld om aanvullende constructies ter verhoging van de biodiversiteit en het effect op de voedselbeschikbaarheid voor watervogels.
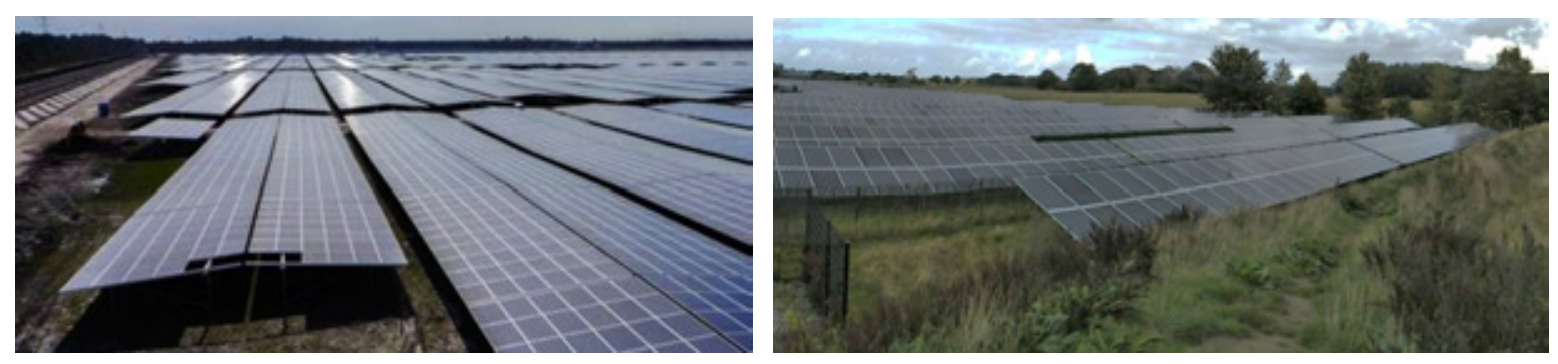

Figuur 23 Ten behoeve van de biodiversiteit is het belangrijk dat er voldoende licht en water op de bodem komt. Zuid geëxponeerde panelen (rechts) voldoen daar doorgaans beter aan dan oost-west geëxponeerde panelen (links). 


\section{De beleving van zonneparken}

\subsection{Definities}

In de vraagstelling rondom het effect van zonneparken op het landschap worden verschillende termen gehanteerd, met name beleving en acceptatie. Afhankelijk van hun definitie, hebben deze twee begrippen meer of minder overlap. Daarom wordt hier eerst een werkdefinitie gegeven voor deze twee begrippen.

Beleving: de term beleving wordt hier smal gedefinieerd, namelijk hoe het landschap bij waarneming ervaren wordt. Bij de beleving gaat het dus om hoe het landschap de zintuigen prikkelt ('streelt' of juist tegen de haren instrijkt) dan wel de waarnemer boeit ('pleases the senses or tickles the mind'). Daarbij speelt het zien, de visuele component, doorgaans een dominante rol, maar is de beleving hier in principe niet toe beperkt. De beleving van het landschap kan daarmee vele facetten hebben. Als het puur de visuele component betreft, dan gaat het om de schoonheid van het landschap ('scenic beauty'). Meer algemeen wordt in (kwantitatief) onderzoek de beleving meestal teruggebracht tot een eendimensionaal oordeel over de belevingswaarde: een hoge of een lage score (De Vries, 2007).

Acceptatie: acceptatie betreft het oordeel over de wenselijkheid dan wel noodzakelijkheid van een voorgenomen of recent uitgevoerde ingreep (hier in het landschap) (zie Busse \& Siebert 2018 voor een genuanceerde discussie over dit begrip)). De belevingswaarde kan daarbij een factor zijn, maar er kunnen daarnaast ook allerlei andere factoren een rol spelen, bijvoorbeeld of men persoonlijk financieel voor- of nadeel heeft bij de ingreep. Maar ook de overtuiging dat een energietransitie noodzakelijk is, kan een belangrijke factor zijn. Acceptatie is belangrijk voor het draagvlak voor de ingreep.

Bij de beleving is het belangrijk om aan te geven wat het belevingsobject precies is. Hier staat niet het zonnepark sec centraal (de 'hardware'), maar het landschap waar het zonnepark na installatie deel van uitmaakt. Het gaat dus meer om de inpassing van het zonnepark (in technische zin) in het landschap, of wellicht zelfs de verrijking die het biedt. Verder is het belangrijk om aan te geven om wiens beleving en/of acceptatie het gaat. Gaat het om de eigenaar van het gebied, omringende bewoners, recreanten en passanten of om de Nederlandse bevolking als geheel? Met name bij acceptatie moge duidelijk zijn dat de financiële belangen bij de voorgestelde ingreep in het landschap niet voor iedereen hetzelfde zullen zijn, zowel wat betreft richting als omvang.

Tot slot speelt voor de acceptatie ook het proces rondom een voorgestelde ingreep een rol. Is het bijvoorbeeld iets dat van buitenaf komt, de burger overkomt, of is diezelfde burger nauw betrokken bij het proces en de totstandkoming van het nieuwe landschap (ook als dit geen financiële implicaties voor die burger heeft)? We zouden kunnen spreken over de beleving van het proces. Deze procesbeleving is van belang, omdat zij, bewust (strategisch) dan wel onbewust, het oordeel over de geplande ingreep/het landschap na de ingreep kan beïnvloeden. De invloed van het proces op de belevingswaarde is naar verwachting groter als het gaat om een ingreep in de eigen leefomgeving en minder groot naarmate het langer geleden is dat het nieuwe landschap is gerealiseerd.

De voorgaande definities en kanttekeningen zijn van belang, omdat zij helpen het onderzoek rondom zonneparken te positioneren. Zo zal in een experimentele studie waarin de deelnemers middels foto's verschillende landschappen voorgelegd krijgen en beoordelen op hun aantrekkelijkheid, met name de visuele factor het oordeel over de belevingswaarde bepalen en lijkt een vraag naar de acceptatie niet aan de orde. Bij een onderzoek naar wat de lokale bevolking vindt van een voorgenomen ingreep staat juist de acceptatie centraal en kan betwijfeld worden of een vraag naar de belevingswaarde (in de hier gedefinieerde enge zin) een 'zuiver' antwoord oplevert, d.w.z. een antwoord dat niet is beïnvloed door of men de ingreep uit andere dan belevingsoverwegingen wel of niet wenselijk vindt. 
Omdat in andere hoofdstukken van dit rapport al naar financiële belangen van bijvoorbeeld agrariërs wordt gekeken, concentreren we ons in dit hoofdstuk op het effect van zonneparken op de belevingswaarde voor mensen zonder directe economische belangen bij het zonnepark, positief dan wel negatief. Daarbij kan grofweg nog een onderscheid gemaakt worden tussen omwonenden en burgers in het algemeen. Omwonenden kunnen een persoonlijke historische band hebben met het specifieke gebied waar de ingreep plaatsvindt. Dit kan hun (oordeel over de) belevingswaarde van het landschap beïnvloeden.

In paragraaf 6.2 wordt ingegaan op de invloed van een zonnepark op de belevingswaarde van het landschap en hoe deze geminimaliseerd kan worden. In paragraaf 6.3 wordt (beknopt) ingegaan op de maatschappelijke acceptatie van zonneparken.

\subsection{Minimaliseren negatieve impact zonneparken qua belevingswaarde}

Bij de aandachtspunten worden drie categorieën onderscheiden (die in de praktijk onderlinge relaties kunnen hebben): de locatie van het zonnepark, de vormgeving van het zonnepark (gegeven de locatie) en mitigerende maatregelen (gegeven locatie en vormgeving). Deze worden hier achtereenvolgens behandeld.

\section{Locatie}

Om het landschap te kunnen beleven, moet men ermee in contact komen. De belevingswaarde ontstaat pas als men het landschap daadwerkelijk beleeft. Als we ons even beperken tot het visuele domein, houdt dit in dat men het landschap moet kunnen zien. Daarom vinden in omgevingsimpactanalyses (Environmental Impact Assessments (EIA) ook wel zichtbaarheidsanalyses plaats: van waaruit kan men het zonnepark zien? Oftewel: hoe groot is het gebied waarvan het landschap wordt beïnvloed (positief dan wel negatief) door de ingreep ('viewshed')? Hiervoor worden vaak GISmodellen gebruikt (Roth et al., 2015). De aandacht voor beleving van het landschap in EIA's is volgens sommige auteurs echter nog gering (Tolli et al., 2016; Scognamiglio, 2016).

Uitgaande van een negatieve impact op de belevingswaarde verdient een locatie die vanaf weinig plekken zichtbaar is (kleine 'viewshed') de voorkeur. Als er sprake is van weinig reliëf in het landschap, wordt de viewshed vooral bepaald door de visuele openheid van het landschap. Hoe opener, vanaf hoe verder zichtbaar. Ook de hoogte van de panelen boven het maaiveld is van invloed op de viewshed: hoe hoger, vanaf hoe verder zichtbaar. Atmosferische condities (helderheid, zicht) kunnen ook nog een rol spelen, maar kunnen van moment tot moment variëren. Eventuele schittering ('glare') kan de zonnepanelen ook op grotere afstand nog zichtbaar maken en zou daarom vermeden moeten worden.

Een wellicht nog belangrijker factor dan de omvang van de viewshed is hoeveel mensen hoe vaak in contact komen met het door de ingreep veranderde landschap. Het valt namelijk te verdedigen dat de maatschappelijke impact van de landschappelijke ingreep groter is naarmate meer mensen er vaker mee worden geconfronteerd (zie ook Sanchéz-Pantoja et al., 2018). Hiervan uitgaande, verdienen locaties met een viewshed waar weinig mensen komen, en dan ook nog niet vaak, de voorkeur. Omwonenden zullen doorgaans vaker met de ingreep geconfronteerd worden dan andere burgers. Hoe de afweging tussen hoeveel mensen en hoe vaak die mensen zicht op het zonnepark hebben het best gemaakt kan worden, is onduidelijk. In het kader van de verdelende rechtvaardigheid ('distributive environmental justice') valt er iets voor te zeggen dat, uitgaande van een gelijkblijvend totaalaantal contactmomenten, meer mensen minder vaak te prefereren valt boven minder mensen vaker. ${ }^{9}$

Een laatste aspect is de mate waarin het zonnepark past in het bestaande landschap (qua beleving). Dit heeft te maken met de vormgeving van het zonnepark zelf (waarover verderop meer), maar ook

9 Dit gaat ervan uit dat er geen gewenning plaatsvindt, d.w.z. dat de negatieve invloed op de belevingswaarde de $1000^{\text {ste }}$ keer dat iemand het zonnepark ziet even groot is als de eerste keer. Overigens heeft de verdelende rechtvaardigheid hier uitsluitend betrekking op de gevolgen voor de belevingswaarde. 
met hoe het bestaande landschap eruitziet en gewaardeerd wordt. Uit onderzoek naar het effect van andere man-made objecten blijkt duidelijk dat naarmate men het landschap vooraf aan de eventuele plaatsing van het object mooier vindt, de negatieve impact van het object groter is. Een aspect dat de belevingswaarde positief beïnvloedt, is hoe natuurlijk men het landschap vindt (natuurlijk van uit burgerperspectief). Daarmee zal naar verwachting ook een zonnepark in een natuurgebied een grotere negatieve invloed hebben dan een in het agrarisch gebied. Een ander aspect is de aanwezigheid van andere man-made objecten: naarmate deze al meer in het landschap voorkomen, zal de negatieve invloed van het toevoegen van een zonnepark op de belevingswaarde kleiner zijn (De Vries et al., 2012).

\section{Vormgeving zonnepark}

Naast de zichtbaarheid van het zonnepark gaat het om de mate van integratie in het omringende landschap (gegeven dat men het zonnepark ziet, in ieder geval deels). Visuele saillantie lijkt daarbij een belangrijke factor: valt het zonnepark op, steekt het af bij de rest van het landschap en trekt het daardoor de aandacht (Sanchéz-Pantoja et al., 2018; zie ook Dupont et al., 2017). Dit betreft de mate waarin het zonnepark afwijkt van andere elementen in het landschap. Dit kan gaan om een contrast in kleur, materiaal (textuur), de vormgeving van het paneel zelf, reflectie, dimensies/schaal, het opstellingspatroon of de gebruiksfunctie. Een object met een hoge visuele saillantie hoeft niet per definitie een negatief effect op de belevingswaarde van het landschap te hebben; in exceptionele gevallen kan het een positief gewaardeerd baken ('landmark') vormen. Denk bijvoorbeeld aan Radio Kootwijk (zie foto). Maar meestal wordt een man-made object met een hoge visuele saillantie in een (semi)natuurlijke omgeving als storend ervaren, als niet passend in het (oorspronkelijke) landschap.

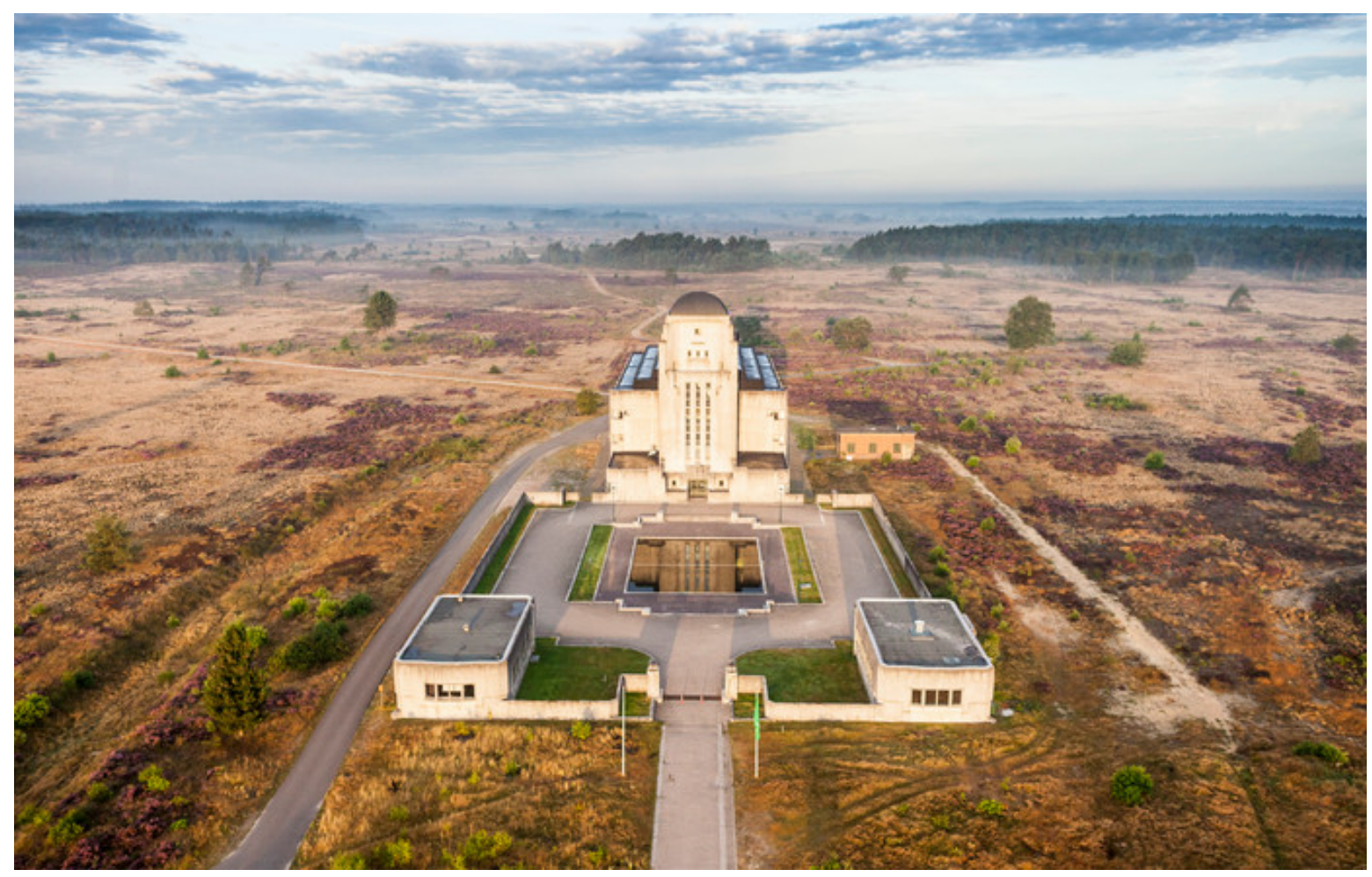

Figuur 24 Radio Kootwijk (Bron: https://www.destentor.nl/apeldoorn/apeldoorn-wel-degelijkaandacht-voor-veiligheidssituatie-in-radio-kootwijk a7e3d4fe/).

Carullo et al. (2013) hebben een expertbenadering gehanteerd om het effect van zonneparken op het landschap te beoordelen, de zogenaamde Landscape Character Assessment (LCA). In deze benadering wordt de term 'visuele saillantie' niet gehanteerd, maar wordt wel gesproken over de (conceptueel sterk overeenkomstige) capaciteit van het landschap om veranderingen op te vangen: "the degree to which a particular landscape character type or area is able to accommodate change without significant effects on its character". De benadering is toegepast op een gebied in Sicilië dat deel uitmaakt van het Natura 2000-netwerk. De onderzoekers concluderen dat het grootste deel van dit gebied geen 
geschikte locatie vormde voor zonnepark; alleen het deel dat agrarisch waardevol was (met kassen) had in hun ogen enige capaciteit voor het huisvesten van een zonnepark. NB Bij het karakter van het landschap gaat het in deze LCA-benadering om meer dan alleen de (visuele) belevingswaarde; zo is ook de invloed van een zonnepark op de ecologische waarde in de analyse meegenomen.

Torres-Sibille et al. (2009) gaan dieper in op de kenmerken van het zonnepark die de mate van visuele saillantie (door hen 'objective aesthetic impact' genoemd) bepalen. Naast de omvang van het zonnepark in het blikveld noemen zij de kleur, het patroon (hoe kunstmatig/regelmatig/'strak') en een variabele die betrekking heeft op het voorkomen van verschillende typen panelen binnen het zonnepark ('concurrence'; deze variabele wordt hier verder buiten beschouwing wordt gelaten). ${ }^{10}$ Volgens de beoordeling door experts heeft de zichtbaarheid in het blikveld de grootste invloed op de impact, gevolgd door de mate waarin de kleur van het zonnepark afwijkt van die van het omringende landschap. Voor de omvang van het zonnepark in het blikveld geldt dat deze niet alleen afhankelijk is van de omvang van het park, maar dat zij kleiner wordt met de afstand tussen waarnemer en park, waarmee dit ook een factor van belang wordt (Fernandez-Jimenez et al., 2015). Binnen de viewshed kan worden uitgegaan van een afnemende impact bij een toenemende afstand (De Vries et al., 2012).

Tot slot: als het zonnepark een heel grote omvang heeft (binnen het zichtveld van de waarnemer), oftewel het blikveld domineert, dan vormt het niet langer een element in het landschap, maar is er sprake van een zonneparklandschap (i.p.v. een landschap met daarin een zonnepark). In dat geval is de vraag wat betreft passendheid of integratie van het zonnepark in het (wijdere) landschap niet langer aan de orde: het zonnepark is het landschap. Maar dan kan nog steeds de vraag gesteld worden hoe aantrekkelijk men dit nieuwe landschap vindt (eventueel relatief ten opzichte van het oorspronkelijke landschap). Ter vergelijking kan gedacht worden aan het kassenlandschap in het Westland; dit type landschap scoort doorgaans laag qua belevingswaarde (zie foto's).

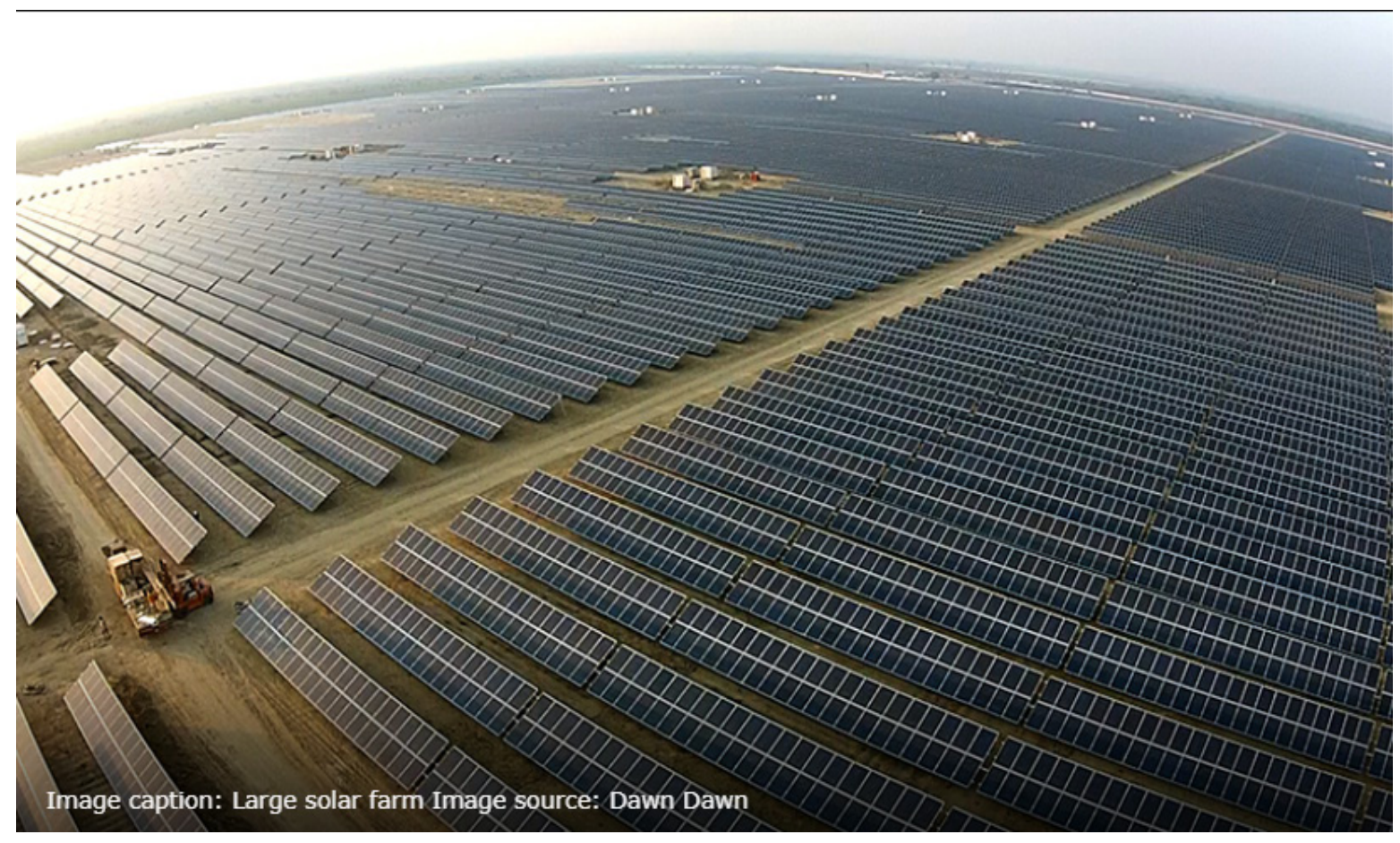

Figuur 25 Zonneparklandschap in Pakistan (Bron: https://www.masterbuilder.co.in/pakistansetting-worlds-largest-solar-park/).

\footnotetext{
10 Deze 'concurrence' lijkt enigszins in de richting van rommeligheid te gaan. Een zonnepark waarbij de panelen heel strak in het gelid staan, komt weinig natuurlijk over. Maar een heel gevarieerde opstelling, al dan niet met meerdere typen panelen, kan als rommelig overkomen en daardoor de beleving negatief beïnvloeden. Van een rommelige opstelling zal in de praktijk niet snel sprake zijn.
} 


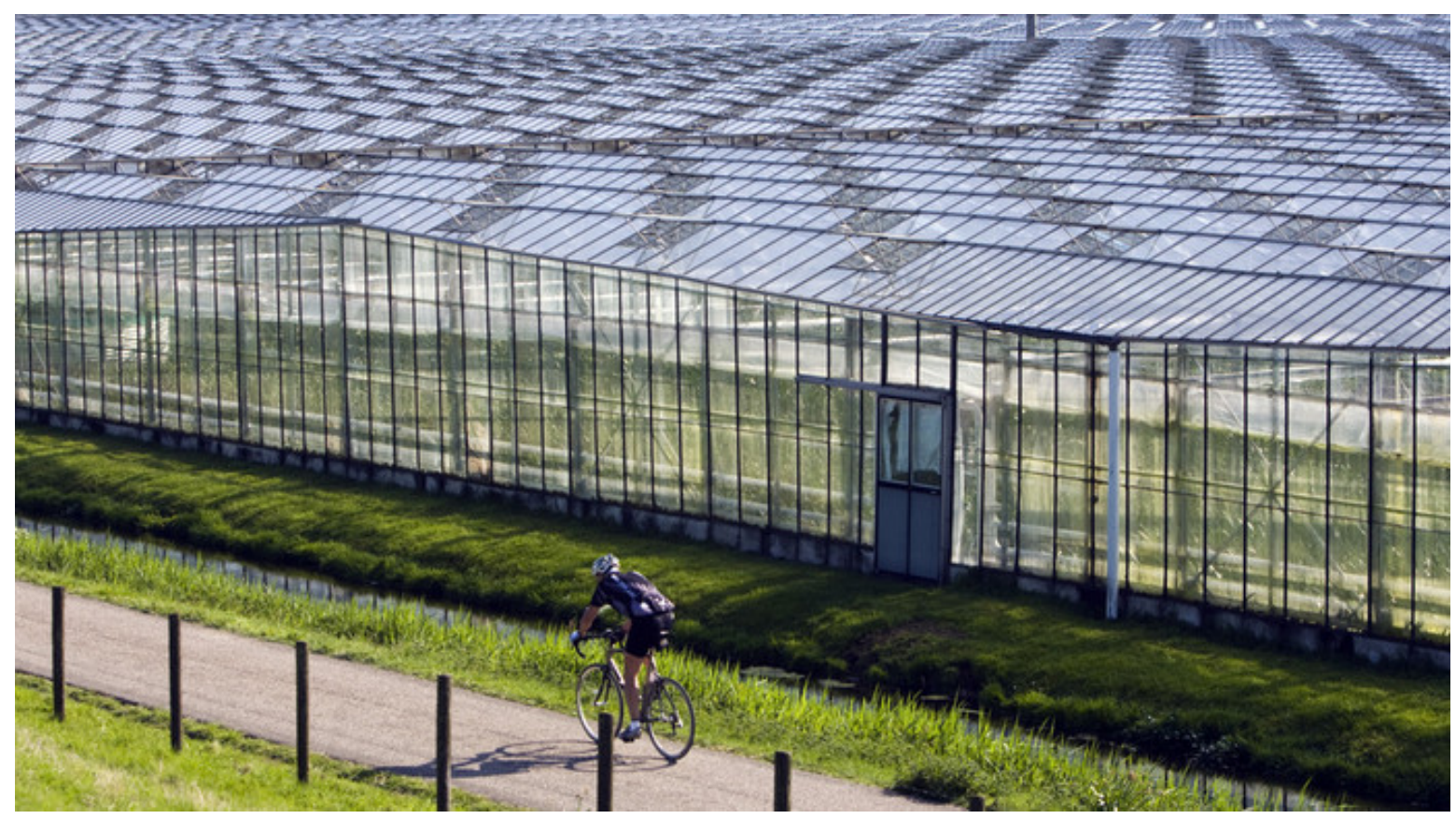

Figuur 26 Kassen in het Westland (Bron: https://www.ad.nl/economie/nieuwe-vaarweg-voorgroenten-en-fruit a6ae5deb/).

\section{Mitigerende maatregelen}

In tegenstelling tot bij windturbines en hoogspanningsmasten lijken er bij zonneparken goede mitigerende maatregelen mogelijk als het gaat om de belevingswaarde van het landschap (zie ook Scognamiglio, 2016). In het vrij vlakke Nederland kan in het geval van laag bij de grond geplaatste panelen afscherming plaatsvinden door middel van bijvoorbeeld heggen. Hierdoor kan het zonnepark compleet aan het oog worden onttrokken. Daarbij moet aangetekend worden dat die afschermende maatregelen zelf (zoals heggen) ook de beleving kunnen beïnvloeden. Het gebruik van vegetatie heeft daarbij het voordeel dat het zelf ook als natuurlijk wordt gezien (uitgaande van een brede natuurdefinitie). Maar ook het type vegetatie speelt hierbij een rol: past deze in/bij het bestaande landschap of niet? Daarnaast maakt elk type afscheiding de mate van openheid van het landschap kleiner. In sommige landschapstypen zal het karakter van het landschap hier meer door veranderen dan in andere. Zeer open landschappen worden minder open, terwijl zo'n afscheiding in kleinschalige landschappen bij een passende vormgeving wellicht nauwelijks opvalt. Vooral door experts wordt aan zeer open landschappen een hoge waarde toegekend ('kernkwaliteit'); dit lijkt door 'gewone burgers' veelal niet te worden gedeeld (zie bijv. Goossen et al., 2011). Desalniettemin is in sommige gebieden door gemeente of provincie het toepassen van bijvoorbeeld hagen als afschermende beplanting voor zonneparken al verboden vanwege de aantasting van de openheid die dit met zich meebrengt. Overigens is een zonnepark zelf (zonder afschermende beplanting) ook een aantasting van de openheid, tenzij de panelen zeer laag bij de grond staan.

\subsection{Maatschappelijke acceptatie van zonneparken}

Balest et al. (2018) hebben gekeken naar de factoren die de keuzes, acties en reacties van de lokale bevolking ten aanzien van energietransitie, zoals gebruikmaken van zonne-energie, beïnvloeden. Op grond van een systematische review komen zij tot 15 dimensies en 41 subdimensies. Het voert te ver om deze hier allemaal te bespreken. Devine-Wright et al. (2017) geven, gebaseerd op de literatuur, een handzaam en informatief overzicht over welke factoren van belang zijn bij de weerstand van de lokale bevolking tegen zoiets als een zonnepark en hoe de kans op acceptatie zo groot mogelijk gemaakt kan worden. Ze geven onder andere de volgende aanbevelingen voor de praktijk:

1. Succesvolle plaatsing hangt samen met legitimiteit en vertrouwen; beide kunnen door vroegtijdige dialoog met en betrokkenheid van burgers bevorderd worden. 
2. De lokale gemeenschap informeren over tot welke aanpassingen in het oorspronkelijke plan hun inbreng heeft geleid, kan het vertrouwen en de sociale acceptatie vergroten.

3. Gemeenschapsprojecten kennen doorgaans een hogere mate van acceptatie dan commerciële projecten en worden veelal ook sneller goedgekeurd.

4. Projecten waarbij de gemeenschap financieel baat heeft bij het zonnepark leiden wellicht niet tot meer sociale acceptatie, maar kunnen er wel voor zorgen dat de verdeling van kosten en baten als eerlijker wordt ervaren door de lokale bevolking.

5. Coördinatie tussen de verschillende overheidslagen, bijvoorbeeld gemeente en provincie, kan gemeenschappen helpen om actief te participeren in projecten die door de gemeenschap getrokken worden, of in projecten met een gedeeld eigenaarschap.

6. Ruimtelijk zoneringsbeleid is nuttig om de zorgen van de belangrijkste stakeholders te coördineren, maar garandeert geen sociale acceptatie.

7. Lokale gemeenschappen zijn wellicht eerder geneigd een project te accepteren als de planners en ontwerpers in hun plannen de lokale identiteit en de verbondenheid van mensen met bepaalde plekken respecteren.

Ze geven ook specifiek aanbevelingen voor het beleid.

Van der Schoor en Scholtens (2015) gaan in op de overgang van passieve acceptatie naar actieve betrokkenheid bij de lokale energietransitie, zoals burgerinitiatieven. Ze gaan specifiek in op de vraag hoe lokale gemeenschapsinitiatieven op dit vlak kunnen bijdragen aan een gedecentraliseerde duurzame energievoorziening. Ze komen tot de conclusie dat een gedeelde visie, de intensiteit van activiteiten op dit gebied en het type organisatie belangrijke factoren zijn voor de sterkte van het 'lokale netwerk'.

Het zou kunnen dat in het stedelijk gebied en in recreatiegebieden de acceptatie voor zonneparken groter is en de inpassing makkelijker. Hier is echter geen wetenschappelijke onderbouwing voor. Een leuk voorbeeld van een combinatie van een natuurpark, recreatiegebied en een zonnepark is Solar Park De Kwekerij in Hengelo (Gld). Een park met bijna 7000 panelen op 7,1 ha. Het solarpark is iedere dag geopend voor het publiek. Het park is geëindigd in de top 3 van de Gelderse Prijs voor Ruimtelijke Kwaliteit 2018. Zie www.nlsolarparkde kwekerij.nl.

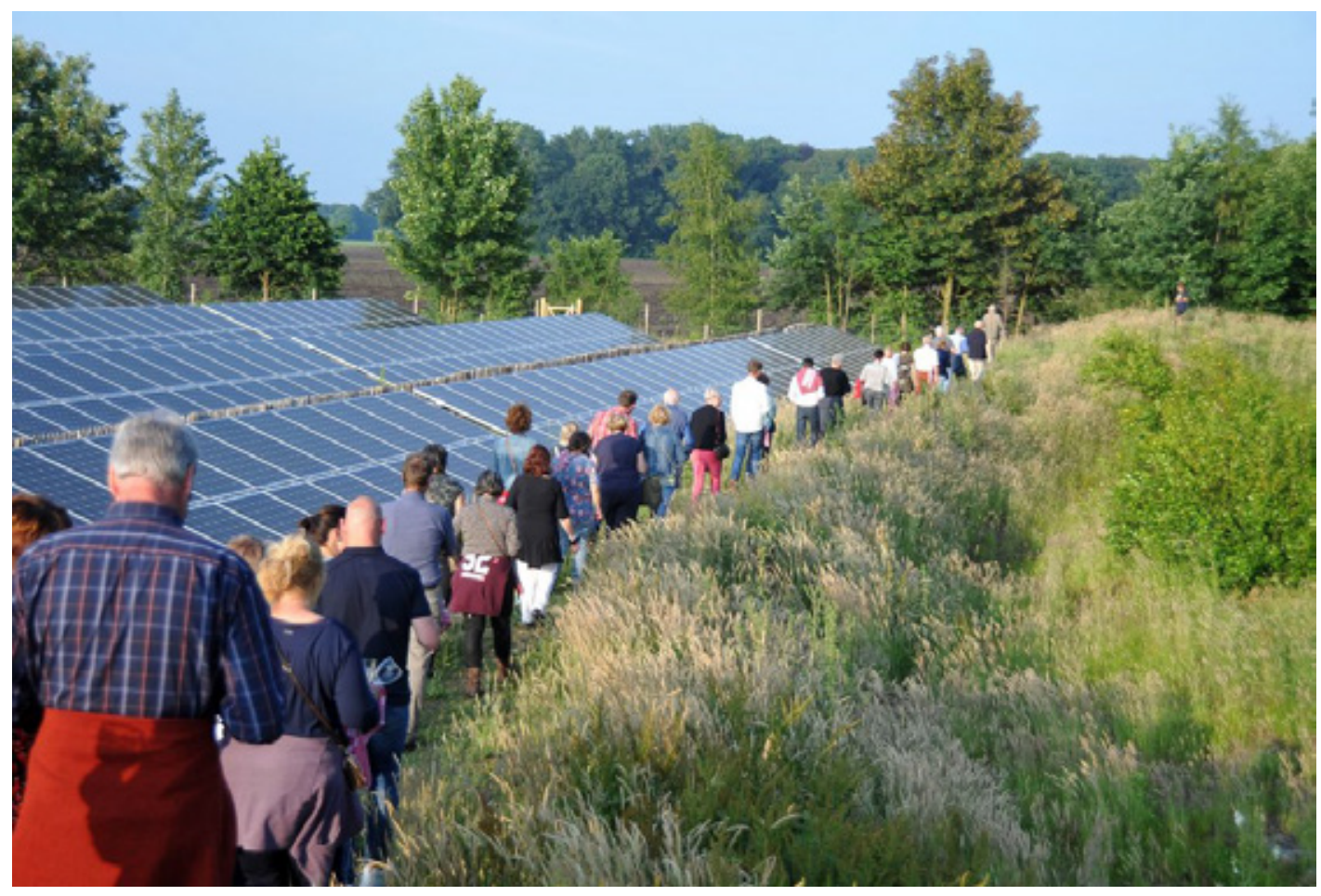

Figuur 27 Solarpark De Kwekerij (bron: https://nlsolarparkdekwekerij.nl). 


\subsection{Conclusies en kennisleemten}

- De belevingswaarde, met name in de zin van hoe mooi mensen het landschap vinden, zal door het realiseren van een zonnepark doorgaans afnemen. Daarmee is niet gezegd dat zij zo'n zonnepark onacceptabel vinden; uit milieuoverwegingen kunnen zij hier bijvoorbeeld toch voor zijn. Voor de acceptatie van het (realiseren van een) zonnepark maakt het naar verwachting inderdaad uit of de omwonenden bij het proces betrokken zijn en zich serieus genomen voelen en of zij hier zelf ook financieel baat bij hebben (dan wel gecompenseerd worden), alhoewel het geen garanties biedt voor een groot maatschappelijk draagvlak. De Green Deal Participatie van de Omgeving bij Duurzame Energieprojecten, waarin het onder andere gaat om het beter betrekken van burgers, lijkt daarmee een goede zaak. Acceptatie lijkt overigens een meer tijdgebonden fenomeen dan beleving: acceptatie speelt vooral vanaf het begin van het proces tot enige tijd na de plaatsing (als het al tot plaatsing komt; zo ja, dan maakt het niet accepteren veelal plaats voor berusting); de belevingswaarde kan langduriger negatief beïnvloed worden door het zonnepark (alhoewel ook hierbij gewenning op kan treden).

- Qua beleving zal de negatieve impact van een zonnepark groter zijn naarmate het landschap in z'n huidige staat hoger gewaardeerd wordt. Meer natuurlijke omgevingen lijken op dit punt minder geschikt dan landbouwgebieden. Maar een andere factor is hoeveel mensen hoe vaak met het zonnepark geconfronteerd worden. Daarvoor geldt: minder is beter. Een zonnepark in een groot bosgebied (waar weinig recreanten komen) kan op dit punt daarom beter scoren dan een zonnepark in een (visueel) zeer open agrarisch gebied nabij bevolkingsconcentraties.

- $\mathrm{Er}$ is nog vrijwel geen onderzoek gedaan naar het effect van verschillende inrichtingsvarianten van zonneparken op de belevingswaarde van het landschap. Wel lijken er goede mogelijkheden voor mitigerende maatregelen, zoals een strook dichte vegetatie rondom het park dat het park aan het zicht onttrekt. Die vegetatie moet dan zelf bij voorkeur wel weer in het landschap passen. Uit onderzoek naar windturbines komt een afnemende negatieve impact per windturbine naar voren. Als dit doorgetrokken wordt naar zonneparken, dan lijkt het voor de beleving beter om minder, maar wel grote zonneparken te hebben dan om veel vrij kleine zonneparken te hebben: de geaggregeerde aantasting van het Nederlandse landschap is dan minder. Voor de acceptatie, met name die van de lokale bevolking, ligt dit waarschijnlijk heel anders.

- In aanvulling op onderzoek à la Green Deal Participatie van de Omgeving bij Duurzame Energieprojecten (dat zich richt op hoe het proces rondom het betrekken van burgers optimaal vorm te geven met het oog op (vooral) acceptatie en beleving), lijkt onderzoek naar de invloed van de locatie, omvang en vormgeving van het zonnepark op (vooral) beleving en acceptatie nodig: dit is er nog nauwelijks. Ook onderzoek naar mogelijke low-tech mitigerende maatregelen lijkt zinvol; deze zouden weleens een grotere (positieve) invloed op de beleving kunnen hebben dan een aangepaste vormgeving van het zonnepark zelf. 


\section{$7 \quad$ Aanbevelingen voor provincies en gemeenten}

Dit rapport laat zien dat er zijn mogelijkheden zijn om zonneparken te combineren met landbouw en natuur en de negatieve effecten op bodem en landschap te verkleinen of te voorkomen. Provincies en gemeenten zijn betrokken bij de vergunningverlening en kunnen op die manier het proces beïnvloeden. In de Provinciale Ruimtelijke Verordening geven provincies regels waaraan ruimtelijke plannen moeten voldoen. De verordening zorgt voor doorwerking naar de gemeenten. Indien een provincie dat wenst, is het mogelijk middels deze verordening het realiseren van zonneparken te optimaliseren. Het is aan de provincies hoe ver ze hierin willen gaan. De vergunningsverlening voor nieuwe zand- en grindwinningen is bijvoorbeeld in veel provincies beperkt. Dit mag alleen nog maar plaatsvinden als middel om een hoofddoel als natuurontwikkeling of recreatie te realiseren. Analoog hieraan zouden ook aanvullende eisen bij nieuwe zonneparken gesteld kunnen worden. Ook gemeenten kunnen aan ontwikkelaars van zonneparken plannen voor nevenfuncties vragen. Het is voor een provincie wellicht niet nodig om per park een beoordeling te geven, maar een strategie op een hoger schaalniveau kan zijn om een projectontwikkelaar altijd een aantal onderwerpen te laten toelichten. Aspecten die daarbij van belang zijn:

\section{Locatiekeuze}

Als je natuurwaarden centraal stelt: kies voor een locatie waar natuurwaarden niet aangetast worden en liefst verbeterd worden. Denk bijvoorbeeld ook aan hydrologische bufferzones rondom Natura 2000-gebieden. Maar voor beleving kunnen weer andere locaties de voorkeur genieten. Vraag aan de projectontwikkelaar hoe er bij de locatiekeuze rekening is gehouden met biodiversiteit, landschap, landbouw en bodemvruchtbaarheid van de grond op lange termijn.

\section{Combinaties met landbouw}

Gekozen moet worden of een dubbel doel wordt nagestreefd of dat maximale elektriciteitsopwekking de voorkeur heeft. Een dubbel doel zal leiden tot een minder intensief zonnepark waar, om dezelfde energieopbrengst te realiseren, een groter oppervlakte zonnepark nodig is. Voor de combinatie landbouw-zonne-energie is van belang:

a. genoeg lichtinval en goede regenwaterverdeling voor voldoende gewasgroei;

b. in het geval van akkerbouw en veeteelt voldoende ruimte voor mens, dier en machine;

c. hoe valt de voorgestelde combinatie binnen de juridische kaders? Bijvoorbeeld: mestplaatsing, natuurcompensatie, (biologische) uitloop en landgebruik. Daarvoor zijn mogelijk aanvullende regels nodig.

\section{Veldopstelling}

Lichtinval op de bodem en een goede regenwaterverdeling zijn essentieel. In het algemeen geldt: hoe ruimer de opstelling, hoe meer kansen voor natuur, biodiversiteit en behoud van de bodemvruchtbaarheid. Het totale ruimtebeslag bij eenzelfde energieproductie wordt daarmee wel groter. Laat de projectontwikkelaar aangeven hoe hij hiermee rekening houdt.

\section{Ecologische inpassing}

Een zonnepark op niet-bemeste grond levert kansen om diversiteit te creëren. Denk bijvoorbeeld aan inheemse bloeiende kruiden, waardoor een aantrekkelijk habitat voor insecten, vogels en andere fauna gecreëerd kan worden. Maar in veenweidengebied kunnen zonneparken wellicht ook gecombineerd worden met hogere waterpeilen, $\mathrm{CO}_{2}$-opslag en misschien zelfs weidevogels uit de omgeving. Indien gewenst: laat de projectontwikkelaar een plan maken voor de ecologische inpassing waaruit blijkt dat dit een belangrijke nevenfunctie van het zonnepark is. 


\section{Landschappelijk inpassing}

De belevingswaarde van het landschap zal door het realiseren van een zonnepark doorgaans afnemen. In een meer gesloten landschap is plaatsing van zicht-afschermende haagstruwelen rondom een zonnepark te prefereren boven hekwerken. Dit kan ook ecologisch voordelen bieden. Maar landschappelijke inpassing is altijd maatwerk. Voor de acceptatie van het realiseren van een zonnepark maakt het uit of de omwonenden bij het proces betrokken zijn en zich serieus genomen voelen en of zij hier zelf ook financieel baat bij hebben. Laat een projectontwikkelaar in het plan aangeven hoe er met deze aspecten wordt omgegaan.

\section{Beheer}

In veel gevallen wordt bij het ontwerp van het zonnepark nog te weinig nagedacht over het beheer na realisatie. Terwijl dit essentieel is voor het ontwikkelen en in stand houden van biodiversiteit. Maaien en afvoeren van het maaisel kan een lastige en kostbare post vormen tussen alle draagconstructies. Daarom kiest men soms voor permanente begrazing door schapen of zelfs onkruidbestrijdingsmiddelen, ecologisch niet de beste opties. Bij een inrichtingsplan hoort ook een ontwerp van het beheer, inclusief de kosten daarvan.

\section{Monitoring}

Om na te gaan of een zonnepark ook daadwerkelijk meerwaarde oplevert aan biodiversiteit of combinaties met landbouwfuncties en hoe we dit kunnen optimaliseren, dient dit gemeten te worden. Diverse provincies geven als randvoorwaarde bij het realiseren van een zonnepark de opdracht om de biodiversiteit en bodemvruchtbaarheid periodiek te (laten) monitoren. Liefst op een gestandaardiseerde manier, zodat gegevens, die openbaar beschikbaar moeten zijn, ook gebruikt kunnen worden voor uitgebreidere onderzoeken. 


\section{Literatuur}

\section{BODEM}

Armstrong, A., Ostlem, N.J., \& Whitaker, J., 2016. Solar park microclimate and vegetation management effects on grassland carbon cycling. Environmental Research Letters 11(7):074016.

Beatty, B., Macknick, J., McCall, J., Braus, G., \& Buckner, D., 2017. Native Vegetation Performance under a Solar PV Array at the National Wind Technology Center (No. NREL/TP- 1900-66218). National Renewable Energy Lab. (NREL), Golden, CO, USA.

Bergsma, H.; Vogels, J.; Burg, A. van den; Bobbink, R., 2018. Is de bodemverzuring in Nederland onomkeerbaar? : door chronische verzurende depositie zal de natuur op droge natuur op droge zandgronden niet vanzelf herstellen. Vakblad natuur bos landschap 144, 4-7.

Bloem, J., C. Koopmans en R. Schils, 2017. Effect van mest op de biologische bodemkwaliteit in de Zeeuwse akkerbouw. Wageningen Environmental Research, Rapport 2843. 54 blz. http://edepot.wur.nl/425171

Bünemann, E.K., Bongiorno, G., Bai, Z., Creamer, R.E., De Deyn, G., de Goede, R., Fleskens, L., Geissen, V., Kuyper, Th.W., Mäder, P., Pulleman, M., Sukkel, W., van Groenigen, J.W. \& Brussaard, L., 2018. Soil quality - A critical review. Soil Biology and Biochemistry 120: 105-125.

Dupraz, C., Marrou, H., Talbot, G., Dufour, L., Nogier, A., \& Ferard, Y., 2011. Combining solar photovoltaic panels and food crops for optimising land use: towards new agrivoltaic schemes. Renewable energy 36(10):2725-2732.

Frambach, M., Liu, Y., Mazolla, L., Schurer, B., Tasiopoulos, L., \& Villar Alegria, E., 2018. Combining solar panels and agriculture. Analysing the impact on soil biodiversity. Studentenrapport Wageningen Universiteit.

Fraunhofer Institute for Solar Energy Systems ISE, 2017. Harvesting the Sun for Power and Produce Agrophotovoltaics Increases the Land Use Efficiency by over 60 Percent.

Hessel, R., J. Stolte en M. Riksen, 2011. Huidige maatregelen tegen water- en winderosie in Nederland. Wageningen, Alterra, Alterra rapport 2131, $50 \mathrm{blz}$.

Klaassen, Raymond H.G.; Schaub, Tonio; Ottens, Henk-Jan; Schotman, A.G.M.; Snethlage, Judit; Mol, G., 2018. Literatuurstudie en formulering richtlijnen voor een ecologische inrichting van zonneparken in de provincies Groningen en Noord-Holland : Eindrapportage. Groningen : University of Groningen, - $39 \mathrm{p}$.

Kok, L., van Eekeren, N., van der Putten, W.H., van den Born, G.J., Schouten, T., \& Rutgers, M., 2017. Zonneparken en bodemafdekking. Bodem 4:18-21.

Majumdar, D. \& Pasqualetti, M.J., 2018. Dual use of agricultural land: Introducing 'agrivoltaics' in Millennium Ecosystem Assessment, 2005. Ecosystems and Human Well- being: Biodiversity Synthesis. World Resources Institute, Washington, DC, USA.

Rutgers, M., T. Schouten, G. Jagers op Akkerhuis, J. Bloem, T. Breure, 2011. Kaderrichtlijn Bodem. Bodembiodiversiteit onder druk bij dalende organische stof. Bodem 21(2), 19-21.

Rutgers, M., Schouten, T., Bloem, J., Buis, E., Dimmers, W., van Eekeren, N., de Goede, R.G.M., Jagers op Akkerhuis, G.A.J.M., Keidel, H., Korthals, G., Mulder, C., Wattel-Koekkoek, E.J.W., 2014. Een indicatorsysteem voor ecosysteemdiensten van de bodem : Life support functions revisited. RIVM Rapport 2014-0145,129 pp. http://edepot.wur.nl/345145

Rutgers, Michiel \& Trinsoutrot Gattin, Isabelle \& Van Leeuwen, Jeroen \& Menta, Cristina \& Gatti, Fabio \& Visioli, Giovana \& Debeljak, Marko \& Trajanov, Aneta \& Bugge Henriksen, Christian \& Creamer, Rachel, 2018. Key indicators and management strategies for soil biodiversity and habitat provisioning. http://landmark2020.eu/

Schouten, Ton, Jaap Bloem, Ron de Goede, Nick van Eekeren, Joachim Deru, Marleen Zanen, Wijnand Sukkel, Derk van Balen, Gerard Korthals en Michiel Rutgers, 2018. Niet-kerende grondbewerking goed voor de bodembiodiversiteit? - Veldexperimenten uitgelicht. Bodem nr. 3 juni 2018, p.20-23. https://library.wur.nl/WebQuery/wurpubs/544251

Semchenko, M., Lepik, M., Götzenberger, L., \& Zobel, K., 2012. Positive effect of shade on plant growth: amelioration of stress or active regulation of growth rate? Journal of Ecology 100:459-466 
Valle, B., Simonneau, T., Sourd, F., Pechier, P., Hamard, P., Frisson, T., ... \& Christophe, A., 2017. Increasing the total productivity of a land by combining mobile photovoltaic panels and food crops. Applied Energy 206:1495-1507.

\section{LANDBOUW}

Aroca-Delgado, R., J. Pérez-Alonso, Á.J. Callejón-Ferre, B. Velázquez-Martí, 8 maart 2018. Compatibility between Crops and Solar Panels: An Overview from Shading Systems, Sustainability 2018, 10, 743; doi:10.3390/su10030743

Bomers, S., A. Meeuwesen, B. Russchen, M. Salvioli, T. Wartena, 30-Jun-16. Technical and financial overview on combining solar panels with growing low revenue crops focused on the coming pilot project in Goeree-Overflakkee, rapportage in het kader van course academic consultancy training WUR

Commissie Deskundigen Meststoffenwet (CDM), 2017. Advies Mestverwerkingspercentages 2018. Wettelijke Onderzoekstaken Natuur \& Milieu, WUR. WOt-technical report 111. 72 blz.; 1 fig.; 58 tab.; 9 ref; 1 bijl. http://library.wur.nl/WebQuery/wurpubs/fulltext/429589

Cotteleer, G., Luijt, J., Kuhlman, J.W. \& C. Gardebroek, 2007. Oorzaken van verschillen in grondprijzen. Een hedonische prijsanalyse van de agrarische grondmarkt. Wageningen, Wettelijke Onderzoekstaken Natuur \& Milieu, WOt-rapport 41. 84 blz.; 8 fig.; 7 tab.; 41 . ref.; 7 bijl. https://edepot. wur.nl/33406

De Boerderij, 27 november 2018, zonnepanelen niet toegestaan in kippenuitloop

De Boerderij, 2018. Impact zonnepark op grondmarkt beperkt. Achtergrond artikel, 17 maart 2018. https://www.boerderij.nl/Home/Achtergrond/2018/3/Impact-zonnepark-op-grondmarkt-beperkt260398E/

De Boerderij, 2018b. Zonnepark niet zonder meer aantrekkelijk. Achtergrond artikel, 31 juli 2018. https://www.boerderij.nl/Home/Achtergrond/2018/7/Zonnepark-niet-zonder-meer-aantrekkelijk315946E/

De Boerderij, 2019. Zonnepark: van duurzame kip naar duurzame energie. Achtergrond artikel, 23 januari 2019. https://www.boerderij.nl/Pluimveehouderij/Achtergrond/2019/1/Zonnepark-vanduurzame-kip-naar-duurzame-energie-384681E/?cmpid=NLC|boerderij_vandaag|2019-0123|Zonnepark:_van_duurzame_kip_naar_duurzame_energie

De Ingenieur, 28 november 2017, Akkerbouw onder zonnepark

De Stentor, 25 november 2018, Oost-Nederland werkt aan 50 nieuwe zonneparken: Invasie van de 'energiecowboys', https://www.destentor.nl/raalte/oost-nederland-werkt-aan-50-nieuwezonneparken-invasie-van-de-energiecowboys ab3ca9c3/

Obergfell, T., September 2016, (Frauenhofer), Agrophotovoltaics - Existing Solution for New Problems, Blog

ROM3D, 2015. Grondgebonden Zonneparken, https://www.rvo.nl/sites/default/files/2016/09/Grondgebonden\%20Zonneparken\%20$\% 20$ verkenning\%20afwegingskadersmetbijlagen.pdf

Ruitenberg, G., R. Jacobs, Juli 2014, Verkenningen mogelijkheden voor het verlagen van het energieverbruik in de melkveehouderij, RVO

RVO, 10-januari 2019, Stimuleringsregeling duurzame energie, https://www.rvo.nl/subsidiesregelingen/stimulering-duurzame-energieproductie/categorie\%C3\%ABn/zon-sde

RVO, prijsvraag zonnestroom, https://www.youtube.com/watch?v=DQdzRsC3qTU

Silvis, 2018. Agrarische grondprijs gedaald. Wageningen Economic Research, Agrimatie, Grondprijs, februari 2018.

https://www.agrimatie. $\mathrm{nl} /$ ThemaResultaat.aspx?subpubID=2232\&themaID =3588\&indicatorID=3589

Spruijt, J., maart 2015, Wat levert een zonneweide per hectare op?, PPO 642 


\section{BIODIVERSITEIT EN ALGEMEEN}

ARGE Monitoring PV-Anlagen. 2007. Leitfaden zur Berücksichtigung von Umweltbelangen bei der Planung von PV-Freiflächenanlagen. https://www.bauberufe.eu/images/doks/pv_leitfaden.pdf (17-08-2018).

Armstrong, A., Ostle, N.J., \& Whitaker, J., 2016. Solar park microclimate and vegetation management effects on grassland carbon cycling. Environmental Research Letters 11(7):074016.

Armstrong, A., Waldron, S., Whitaker, J., \& Ostle, N.J., 2014. Wind farm and solar park effects on plant-soil carbon cycling: uncertain impacts of changes in ground-level microclimate. Global change biology 20(6):1699-1706.

Beatty, B., Macknick, J., McCall, J., Braus, G., \& Buckner, D., 2017. Native Vegetation Performance under a Solar PV Array at the National Wind Technology Center (No. NREL/TP- 1900-66218). National Renewable Energy Lab. (NREL), Golden, CO, USA.

Bloem, J. \& Korthals, G. In voorbereiding. Soil Health Index - Biologische Indicatoren voor de Nederlandse toepassing. Concept rapport Wageningen Environmental Research, september 2018.

BirdLife Europe, 2011. Meeting Europe's renewable energy targets in harmony with nature. http://www.energiewende-

naturvertraeglich.de/index.php\%3Fid=1091\&L=1\&tx_fedownloads_pi2[download] = 3851 (17-08-2018).

Bos, J.F.F.P., Sierdsma, H., Schekkerman, H., \& Scharenburg, C.V., 2010. Een veldleeuwerik zingt niet voor niets!: schatting van kosten van maatregelen voor akkervogels in de context van een veranderend gemeenschappelijk landbouwbeleid (No. 107). Wettelijke Onderzoekstaken Natuur \& Milieu.

BRE, 2014. Biodiversity guidance for solar developments. https://www.bre.co.uk/filelibrary/pdf/Brochures/NSC-Biodiversity-Guidance.pdf\%0A (08-08-2018).

BügelHajema, 2018. Vogelvriendelijke inrichting Zonnepark Van Boekerenweg Stadskanaal.

CMS, 2014. Renewable energy technologies and migratory species - guidelines for sustainable deployment.

https://www.cms.int/sites/default/files/document/Doc_10_2_2_Guidelines_Renewable_Energy_E. pdf (28-08-2018).

DeVault, T.L., Seamans, T.W., Schmidt, J.A., Belant, J.L., Blackwell, B.F., Mooers, N., Tyson, L.A., \& Van Pelt, L., 2014. Bird use of solar photovoltaic installations at US airports: implications for aviation safety. Landscape and Urban Planning 122:122-128.

Dupraz, C., Marrou, H., Talbot, G., Dufour, L., Nogier, A., \& Ferard, Y., 2011. Combining solar photovoltaic panels and food crops for optimising land use: towards new agrivoltaic schemes. Renewable energy 36(10):2725-2732.

Dutch New Energy Research 2019. Nationaal Solar Trendrapport 2019

Eelerwoude, 2018. Landschappelijke inpassing Zonnepark Midden Groningen. https://chintsolar.nl/wpcontent/uploads/2018/05/180227.Inrichting_beheer_Landsch_inpassing_SP_MG.pdf (22-08-2018).

Engels BWR \& Kleyheeg-Hartman JC. 2016. Natuurtoets zonnepark Haringvliet. Bureau Waardenburg. https://www.commissiemer.nl/projectdocumenten/00001056.pdf?documenttitle=Bijlage 4C Natuurtoets zonnepark Haringvliet.pdf (22-08-2018).

Feltwell, J., 2013. Are photovoltaic solar arrays an influencing factor in avian mortality? Newsletter of the Kent Field Club 77:18-25.

Fischer, J., Brosi, B., Daily, G.C., Ehrlich, P.R., Goldman, R., Goldstein, J., ... \& Ranganathan, J., 2008. Should agricultural policies encourage land sparing or wildlife-friendly farming? Frontiers in Ecology and the Environment 6(7):380-385.

Folkers, W., W. van Sark, C. de Keizer, W. van Hooff \& M. van den Donker, 2017. ROADMAP PV Systemen en Toepassingen. Studie uitgevoerd in opdracht van de Rijksdienst voor Ondernemend Nederland (RVO) in samenwerking met de TKI Urban Energy.

Frambach, M., Liu, Y., Mazolla, L., Schurer, B., Tasiopoulos, L., \& Villar Alegria, E., 2018. Combining solar panels and agriculture. Analysing the impact on soil biodiversity. Studentenrapport Wageningen Universiteit.

Fraunhofer Institute for Solar Energy Systems ISE, 2017. Harvesting the Sun for Power and Produce Agrophotovoltaics Increases the Land Use Efficiency by over 60 Percent. 
Fthenakis, V., Blunden, J., Green, T., Krueger, L., \& Turney, D., 2011. Large photovoltaic power plants: wildlife impacts and benefits. 2011 37th IEEE Photovoltaic Specialists Conference.

GNMF. 2018. Handreiking: beleid en criteria voor zonnevelden. https://www.gnmf.nl/wpcontent/uploads/2018/04/20180424-GNMF-handreiking-zonnevelden.pdf (29-08-2018).

Griffiths, B.S., Faber, J., \& Bloem, J., 2018. Applying soil health indicators to encourage sustainable soil use: The transition from scientific study to practical application. Sustainability (Switzerland) 10(9):3021.

Groen, R. \& L. Lysen, 2018. Drijvend Zonnepark Noorder IJPlas. Quick scan kaderrichtlijn water en wet natuurbescherming. Arcadis Nederland B.V.

Guerin, T., 2017. A case study identifying and mitigating the environmental and community impacts from construction of a utility-scale solar photovoltaic power plant in eastern Australia. Solar Energy 146:94-104.

Guiller, C., Affre, L., Deschamps-Cottin, M., Geslin, B., Kaldonski, N., \& Tatoni, T., 2017. Impacts of solar energy on butterfly communities in mediterranean agro-ecosystems. Environmental Progress and Sustainable Energy 36:1817-1823.

Harrison, C., Lloyd, H., \& Field, C., 2017. Evidence review of the impact of solar farms on birds, bats and general ecology. Natural England. http://publications.naturalengland.org.uk/file/6000213410447360 (09-08-2018).

Heindl, M., 2014. Mounting structure of a solar module as nesting site for a Red-backed Shrike Lanius collurio. Ornithologischer Rundbrief Mecklenburg-Vorpommern 48:87-89.

Heindl, M., 2016. Development of the breeding populations of Whinchat and Corn Bunting in an openarea photovoltaic plant near Demmin. Ornithologischer Rundbrief Mecklenburg-Vorpommern 48:303-307.

https://www.umweltplan.de/media/download/veroeffentlichungen/Martin_Heindl_Braunkehlchen_ Grauammer_Photovoltaik_Anlage.pdf (02-11-2018).

Herden, C., Rassmus, J., \& Gharadjedaghi, B., 2009. Naturschutzfachliche Bewertungsmethoden von Freilandphotovoltaikanlagen. BfN-Skripten 247.

Horváth, G., Blahó, M., Egri, Á., Kriska, G., Seres, I., \& Robertson, B., 2010. Reducing the maladaptive attractiveness of solar panels to polarotactic insects. Conservation Biology 24:1644-1653.

Horváth, G., Kriska, G., Malik, P., Robertson, B., 2009. Polarized light pollution: a new kind of ecological photopollution. Frontiers in Ecology and the Environment 7:317-325.

Jeal, C., 2015. The impact of a "trough" Concetrated Solar Power facility on birds and other animals in the Northern Cape, South Africa. University of Cape Town.

https://open.uct.ac.za/bitstream/handle/11427/25010/thesis_sci_2017_jeal_corey.pdf?sequence= 1 (17-08-2018).

Jenkins, A.R., Ralston-Paton, S., \& Smit-Robinson, H.A., 2017. Best practice guidelines: birds \& solar energy. BirdLife South Africa. https://www.birdlife.org.za/documents/renewable-energy/solarenergy/988-blsa-birds-solar-energy-2017 (23-08-2018).

Kagan, R.A., Viner, T.C., Trail, P.W., \& Espinoza, E.O., 2014. Avian mortality at solar energy facilities in southern California: a preliminary analysis. National Fish and Wildlife Fornesics Laboratory. https://alternativeenergy.procon.org/sourcefiles/avian-mortality-solar-energy-ivanpah-apr2014.PDF (09-08-2018).

Kok, L., van Eekeren, N., van der Putten, W.H., van den Born, G.J., Schouten, T., \& Rutgers, M., 2017. Zonneparken en bodemafdekking. Bodem 4:18-21.

Lambers, I.H.R., 2016. Effecten van zonne park Hijken op beschermde soorten en gebieden. Bureau Waardenburg.

https://www.middendrenthe.nl/website/document/docnr/2828442,,3768338,/Ecologisch onderzoek .pdf (22-08-2018).

Lamont, L.A. \& El Chaar, L., 2011. Enhancement of a stand-alone photovoltaic system's performance: reduction of soft and hard shading. Renewable Energy 36:1306-1310.

Lieder, K. \& Lumpe, J., 2012. Vögel im Solarpark - eine Chance für den Artenschutz? http://archiv.windenergietage.de/20F3261415.pdf (09-08-2018).

Majumdar, D. \& Pasqualetti, M.J., 2018. Dual use of agricultural land: Introducing 'agrivoltaics' in Millennium Ecosystem Assessment, 2005. Ecosystems and Human Well- being: Biodiversity Synthesis. World Resources Institute, Washington, DC, USA.

McCrary, M.D., McKernan, R.L., Schreiber, R.W., Wagner, W.D., \& Sciarrotta, T.C., 1986. Avian mortality at a solar energy power plant. Journal of Field Ornithology 57:135-141. 
Montag, H., Parker, G., \& Clarkson, T., 2016. The effects of solar farms on local biodiversity: a comparative study. Clarkson \& Woods and Wychwood Biodiversity. http://www.solartrade.org.uk/wp-content/uploads/2016/04/The-effects-of-solar-farms-on-local-biodiversitystudy.pdf (08-08-2018).

NABU. 2010. Kriterien für naturverträgliche Photovoltaik-Freiflächenanlagen. https://www.nabu.de/imperia/md/content/nabude/energie/solarenergie/170629-nabu-kriteriensolarparks.pdf (13-08-2018).

Ottburg, F. \& B. Cornelissen, 2018. Zonnepark Uden wil zich inzetten voor wilde bijen. Wat kunnen zij doen? Wageningen Environmental Research.

Peschel, T., 2010. Solar parks - opportunities for biodiversity. Renews Special 45.

Phalan, B., Onial, M., Balmford, A., \& Green, R.E., 2011. Reconciling food production and biodiversity conservation: land sharing and land sparing compared. Science 333(6047):1289-1291.

Provincie Fryslân, 2017. Sinnefjilden yn it lânskip. https://www.fryslan.frl/document.php?m=7\&fileid=27316\&f=74bff86465c36f6d482a3dfa7ac672f2 \&attachment=1 (29-08-2018).

Provincie Groningen, 2018. Handreiking: locatiekeuze en ontwerp zonneparken. https://www.provinciegroningen.nl/fileadmin/user_upload/Documenten_2017/Downloads/Handrei king_locatiekeuze_en_ontwerp_zonneparken_feb_2018.pdf (30-08-2018).

Provincie Noord-Holland, 2016. Nota Perspectief voor Zon in Noord-Holland. https://www.noordholland.nl/dsresource?objectid=18561959-22e8-4604-8019-d2d829e8053f\&type=PDF (29-08-2018).

Provincie Overijssel, 2017. Handreiking kwaliteitsimpuls zonnevelden. https://www.overijssel.nl/publish/pages/166063/handreiking_kwaliteitsimpuls_zonnevelden_def.p df (30-08-2018).

Raab, B., 2015. Erneuerbare Energien und Naturschutz - Solarparks können einen Beitrag zur Stabilisierung der biologischen Vielfalt leisten. ANLiegen Natur 37:67-76.

RSPB, 2014. Solar energy - RSPB policy briefing, December 2014. http://ww2.rspb.org.uk/Images/Solar_power_briefing_tcm9-273329.pdf (09-08-2018).

Semchenko, M., Lepik, M., Götzenberger, L., \& Zobel, K., 2012. Positive effect of shade on plant growth: amelioration of stress or active regulation of growth rate? Journal of Ecology 100:459-466

Sinha, P., Hoffman, B., Saker, J., \& Althouse, L., 2018. Best practices in responsible land use for improving biodiversity at a utility-scale solar facility. Case Studies in the Evironment.

Smit, H.A., 2011. Guidelines to minimise the impact on birds of solar facilities and associated Infrastructure in South Africa. http://www.the-eis.com/data/literature/Solar guidelines_version2.pdf (09-08-2018).

Száz, D., Mihályi, D., Farkas, A., Egri, Á., Barta, A., Kriska, G., Robertson, B., \& Horváth, G., 2016. Polarized light pollution of matte solar panels: anti-reflective photovoltaics reduce polarized light pollution but benefit only some aquatic insects. Journal of Insect Conservation 20:663-675.

Taylor, R., 2014. Potential ecological impacts of ground-mounted photovoltaic solar panels in the UK: an introduction and literature review. BSG Ecology. http://www.bsg-ecology.com/wpcontent/uploads/2015/01/Solar-panels-and-wildlife-review_RT_FINAL_140109.pdf (30-08-2018).

Tröltzsch, P. \& Neuling, E., 2013. Die Brutvögel großflächiger Photovoltaikanlagen in Brandenburg. Vogelwelt 134:155-179.

Valle, B., Simonneau, T., Sourd, F., Pechier, P., Hamard, P., Frisson, T., ... \& Christophe, A., 2017. Increasing the total productivity of a land by combining mobile photovoltaic panels and food crops. Applied Energy 206:1495-1507.

Veenstra, A., 2015. Ruimte voor zonne-energie in Nederland 2020-2050. Analyse van ruimtelijke groeikansen en knelpunten voor zonne-energie toepassingen in Nederland. Holland Solar.

Visser, E., V. Perold, S. Ralston-Paton, A.C. Cardenal \& P.G. Ryan, 2018. Assessing the impacts of a utility-scale photovoltaic energy facilty on birds in the Northern Cape, South Africa. University of Cape Town. Renewable Energy 2018:1-10

Walston, L.J., Rollins, K.E., LaGory, K.E., Smith, K.P., \& Meyers, S.A., 2016. A preliminary assessment of avian mortality at utility-scale solar energy facilities in the United States. Renewable Energy 92:405-414.

WWF, 2013. Solar PV atlas: solar power in harmony with nature. http://awsassets.panda.org/downloads/solar_pv_atlas_final_screen_version_feb_2013.pdf (29-08-2018). 


\section{BELEVING}

Balest, J., Pisani, E., Vettorato, D., \& Secco, L., 2018. Local reflections on low-carbon energy systems: A systematic review of actors, processes, and networks of local societies. Energy Research \& Social Science, 42, 170-181.

Busse, M., \& Siebert, R., 2018. Acceptance studies in the field of land use-A critical and systematic review to advance the conceptualization of acceptance and acceptability. Land Use Policy, 76, 235-245.

Carullo, L., Russo, P., Riguccio, L., \& Tomaselli, G., 2013. Evaluating the landscape capacity of protected rural areas to host photovoltaic parks in Sicily. Nat. Resour, 4, 460-72.

Devine-Wright, P., Devine-Wright, H., \& Cowell, R., 2016. What do we know about overcoming barriers to infrastructure sitting in local areas. Report commissioned by the Department of Energy \& Climate Change (UK).

Dupont, L., Ooms, K., Antrop, M., \& Van Etvelde, V., 2017. Testing the validity of a saliency-based method for visual assessment of constructions in the landscape. Landscape and Urban Planning, 167, 325-338.

Fernandez-Jimenez, L.A., Mendoza-Villena, M., Zorzano-Santamaria, P., Garcia-Garrido, E., Lara-Santillan, P., Zorzano-Alba, E., \& Falces, A., 2015. Site selection for new PV power plants based on their observability. Renewable Energy, 78, 7-15.

Goossen, C.M., M. Sijtsma, H. Meeuwsen en J. Franke, 2011. Vijf jaar daarmoetikzijn; Het ideale landschap volgens de Nederlanders op basis van analyse van de website www.daarmoetikzijn.nl. Wageningen, Alterra, Alterra-rapport 2197.

Sánchez-Pantoja, N., Vidal, R., \& Pastor, M.C., 2018. Aesthetic impact of solar energy systems. Renewable and Sustainable Energy Reviews, 98, 227-238.

Schoor, T. van der, \& Scholtens, B., 2015. Power to the people: Local community initiatives and the transition to sustainable energy. Renewable and Sustainable Energy Reviews, 43, 666-675.

Scognamiglio, A., 2016. 'Photovoltaic landscapes': Design and assessment. A critical review for a new transdisciplinary design vision. Renewable and Sustainable Energy Reviews, 55, 629-661.

Tolli, M., Recanatesi, F., Piccinno, M., \& Leone, A., 2016. The assessment of aesthetic and perceptual aspects within environmental impact assessment of renewable energy projects in Italy. Environmental Impact Assessment Review, 57, 10-17.

Torres-Sibille, A., Cloquell-Ballester, V.A., Cloquell-Ballester, V.A., \& Ramírez, M.Á.A., 2009. Aesthetic impact assessment of solar power plants: An objective and a subjective approach. Renewable and Sustainable Energy Reviews, 13(5), 986-999.

Vries, S. de, 2007. Veranderende landschappen en hun beleving: verkenning van het effect van het veranderd zijn op zich (No. 43). Wettelijke Onderzoekstaken Natuur \& Milieu.

Vries, S. de, Groot, M. de, \& Boers, J., 2012. Eyesores in sight: quantifying the impact of man-made elements on the scenic beauty of Dutch landscapes. Landscape and Urban Planning, 105(1-2), 118-127. 
Wageningen Environmental Research Postbus 47

6700 AA Wageningen

T 0317480700

www.wur.nl/environmental-research

Wageningen Environmental Research Rapport 2945

ISSN 1566-7197
De missie van Wageningen University \& Research is 'To explore the potential of nature to improve the quality of life'. Binnen Wageningen University \& Research bundelen Wageningen University en gespecialiseerde onderzoeksinstituten van Stichting Wageningen Research hun krachten om bij te dragen aan de oplossing van belangrijke vragen in het domein van gezonde voeding en leefomgeving. Met ongeveer 30 vestigingen, 5.000 medewerkers en 10.000 studenten behoort Wageningen University \& Research wereldwijd tot de aansprekende kennisinstellingen binnen haar domein. De integrale benadering van de vraagstukken en de samenwerking tussen verschillende disciplines vormen het hart van de unieke Wageningen aanpak. 



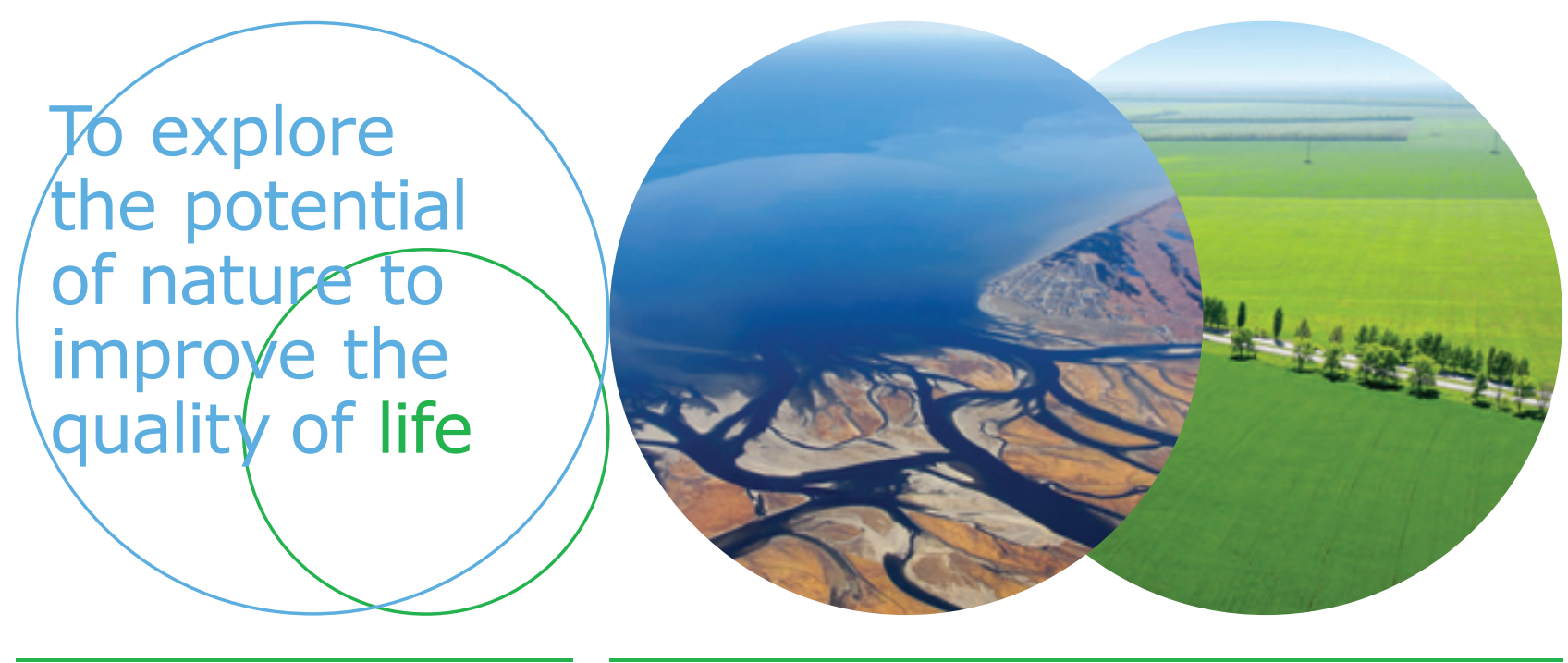

Wageningen Environmental Research Postbus 47

$6700 \mathrm{AB}$ Wageningen

T 317480700

www.wur.nl/environmental-research

Rapport 2945

ISSN 1566-7197
De missie van Wageningen University \& Research is 'To explore the potential of nature to improve the quality of life'. Binnen Wageningen University \& Research bundelen Wageningen University en gespecialiseerde onderzoeksinstituten van Stichting Wageningen Research hun krachten om bij te dragen aan de oplossing van belangrijke vragen in het domein van gezonde voeding en leefomgeving. Met ongeveer 30 vestigingen, 5.000 medewerkers en 10.000 studenten behoort Wageningen University \& Research wereldwijd tot de aansprekende kennisinstellingen binnen haar domein. De integrale benadering van de vraagstukken en de samenwerking tussen verschillende disciplines vormen het hart van de unieke Wageningen aanpak. 